\title{
Thermal Characterization of Molten Salt Systems
}

Toni Y. Gutknecht

Guy L. Fredrickson

September 2011

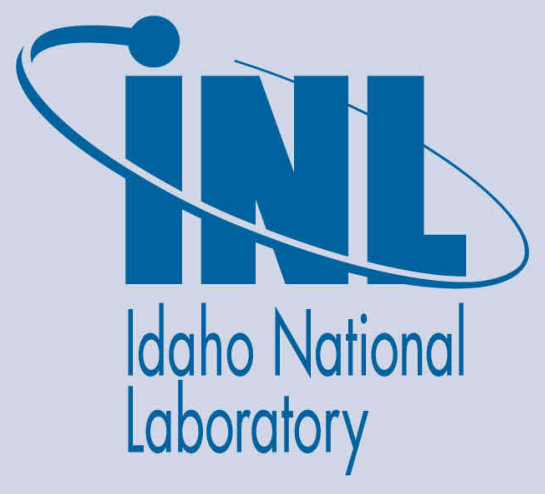

The INL is a U.S. Department of Energy National Laboratory operated by Battelle Energy Alliance 
INL/EXT-11-23511

FCRD-SWF-2011-000364

\title{
Thermal Characterization of Molten Salt Systems
}

Toni Y. Gutknecht

Guy L. Fredrickson

September 2011

\author{
Idaho National Laboratory \\ Fuel Cycle Research \& Development \\ Idaho Falls, Idaho 83415
}

http://www.inl.gov

Prepared for the

U.S. Department of Energy

Office of Nuclear Energy

Under DOE Idaho Operations Office

Contract DE-AC07-05ID14517 


\section{DISCLAIMER}

This information was prepared as an account of work sponsored by an agency of the U.S. Government. Neither the U.S. Government nor any agency thereof, nor any of their employees, makes any warranty,

expressed or implied, or assumes any legal liability or responsibility for the accuracy, completeness, or usefulness, of any information, apparatus, product, or process disclosed, or represents that its use would not infringe privately owned rights. References herein to any specific commercial product, process, or service by trade name, trade mark, manufacturer, or otherwise, does not necessarily constitute or imply its endorsement, recommendation, or favoring by the U.S. Government or any agency thereof. The views and opinions of authors expressed herein do not necessarily state or reflect those of the U.S. Government or any agency thereof. 


\section{SUMMARY}

This report fulfills Level 3 Milestone No. M31SW050702 titled "Complete Final Report of Thermal Analysis Study" for FY 2011 within the Department of Energy (DOE) Work Package No. FTIN11SW0507 titled "Fundamental Properties of TRU-Bearing Chloride Salt". This work package falls under the Fuel Cycle Research \& Development (FCR\&D) Program 1.02.03.11 titled "ROK Feasibility Study". (It was formerly in FCR\&D Program 1.02.03.05 titled "Fundamental Science and Methods Development".)

The phase stability of molten salts in an electrorefiner (ER) may be adversely affected by the buildup of sodium, fission products, and transuranics in the electrolyte. Potential situations that need to be avoided are the following: (1) salt freezing due to an unexpected change in the liquidus temperature, (2) phase separation or non-homogeneity of the molten salt due to the precipitation of solids or formation of immiscible liquids, and (3) any mechanism that can result in the separation and concentration of fissile elements from the molten salt. Any of these situations would result in an off-normal condition outside the established safety basis for electrorefiner (ER) operations.

The stability (and homogeneity) of the phases can potentially be monitored through the thermal characterization of the salts, which can be a function of impurity concentration. This report describes the experimental results of typical salts compositions, which consist of chlorides of potassium, lithium, strontium, samarium, praseodymium, lanthanum, barium, cerium, cesium, neodymium, sodium and gadolinium chlorides as a surrogate for both uranium and plutonium, used for the processing of used nuclear fuels. 


\section{CONTENTS}

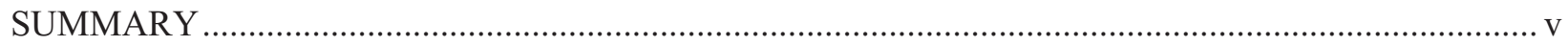

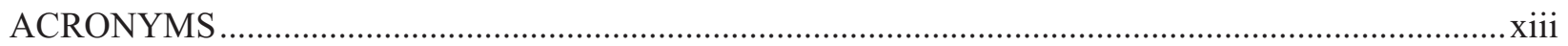

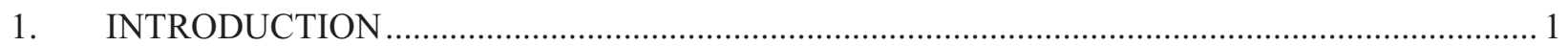

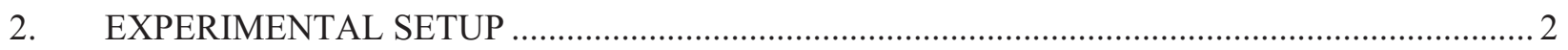

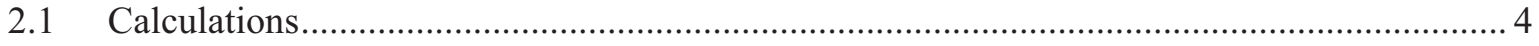

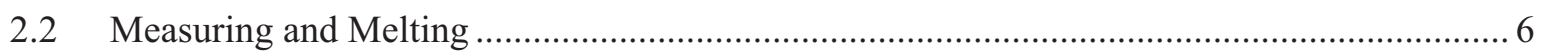

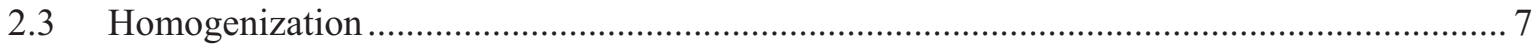

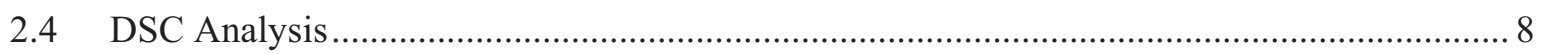

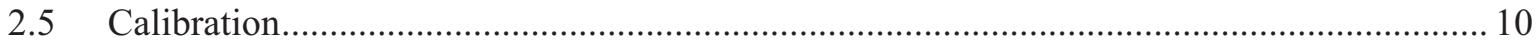

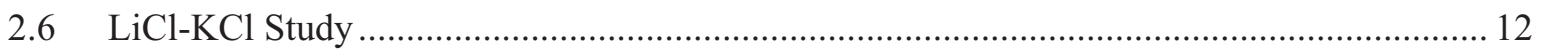

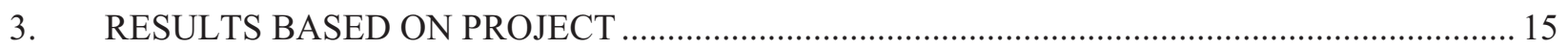

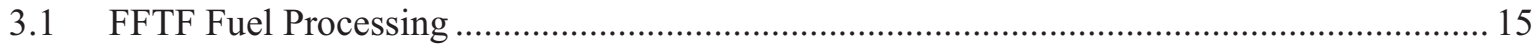

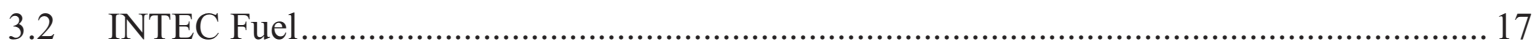

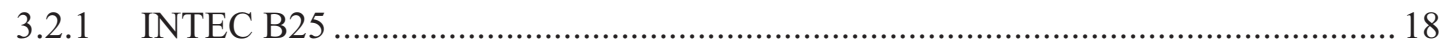

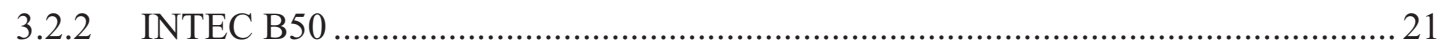

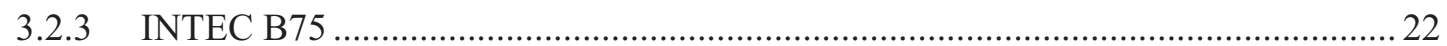

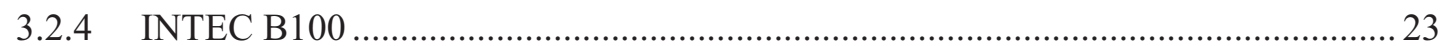

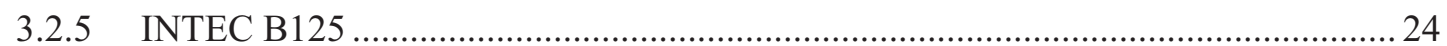

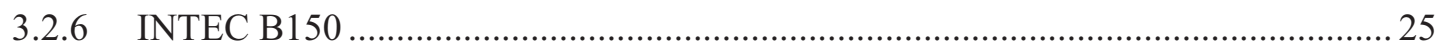

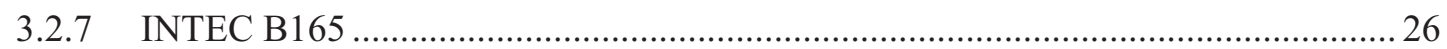

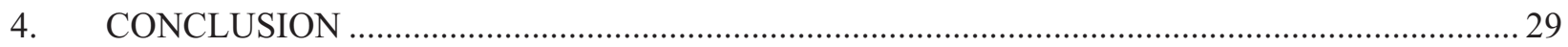

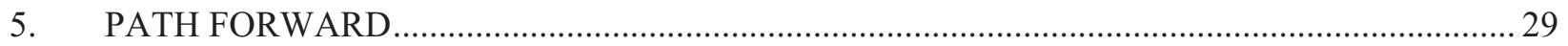

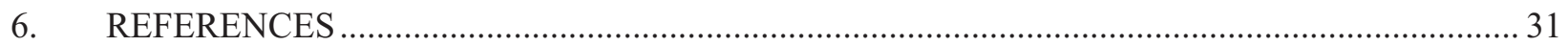

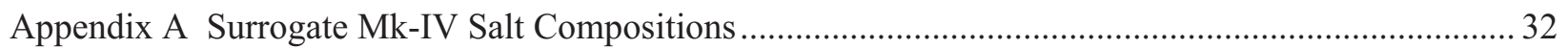

Appendix B Calibration of Stainless Steel Gold Plated DSC Crucibles ................................................. 38

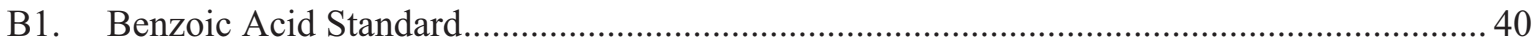

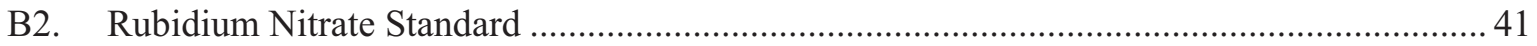

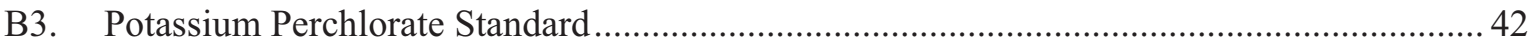

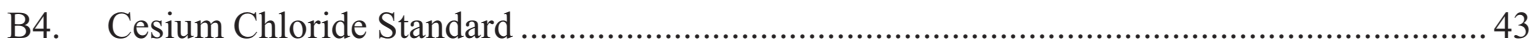

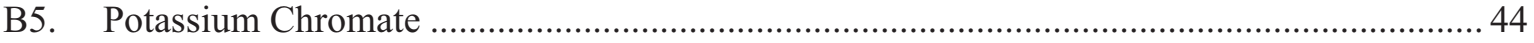

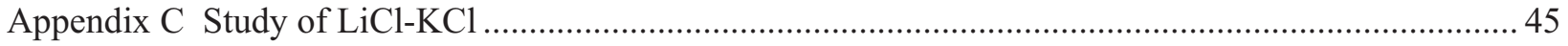

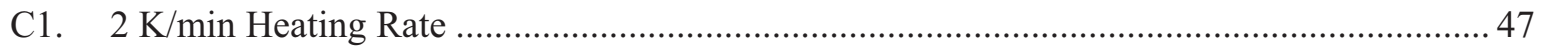

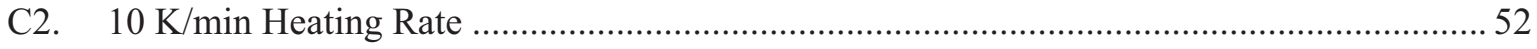

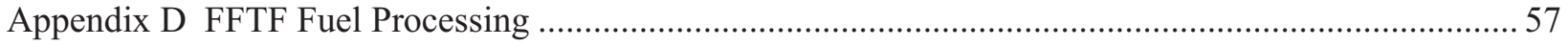




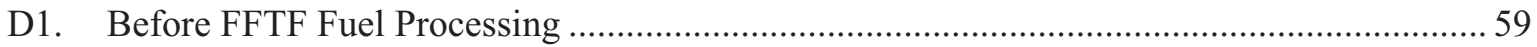

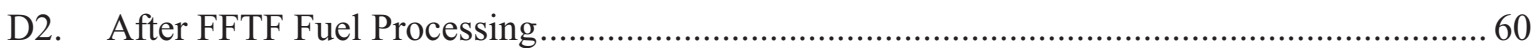

D3. Comparison Before and After FFTF Fuel Processing........................................................ 61

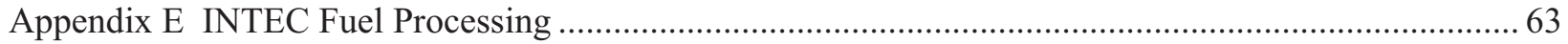

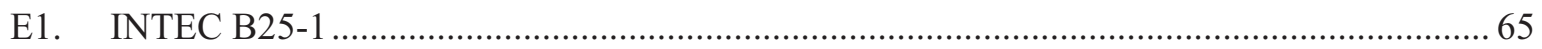

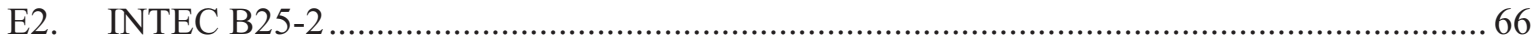

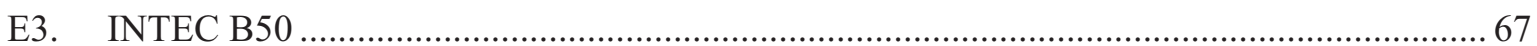

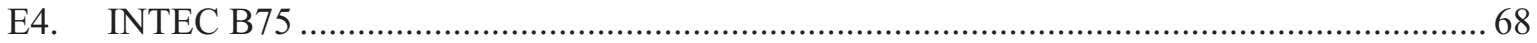

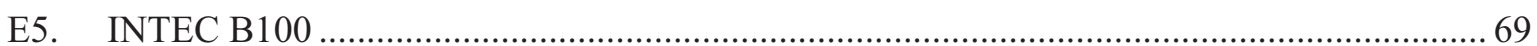

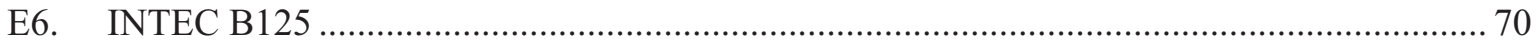

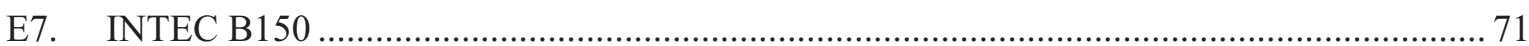

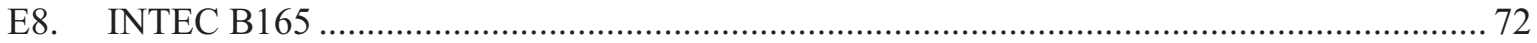

\section{FIGURES}

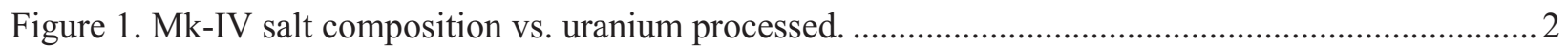

Figure 2. Argon atmosphere, moisture and oxygen controlled glovebox located in WCL......................... 3

Figure 3. Combined metal chloride salts in Ni crucible ........................................................................ 6

Figures $4 \mathrm{a}$ and $4 \mathrm{~b}$. Homogenous molten salt (INTEC B25) and non-homogenous molten salt

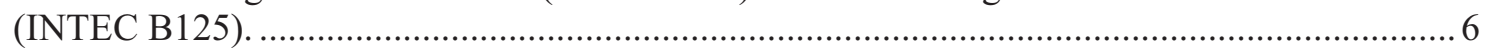

Figure $5 \mathrm{a}-5 \mathrm{~d}$. INTEC B75 as molten sample cools to room temperature. ............................................. 7

Figure 6. Piece of crystallized salt showing non-homogeneity of $15 \mathrm{~g}$ ingot. .......................................... 8

Figure 7. Agate mortar and pestle with crushed salt....................................................................... 8

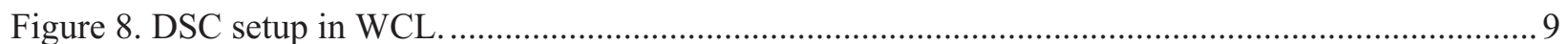

Figure 9. DSC crucible, gold plated chrome nickel steel crucible lid, seal, and pan................................ 9

Figure $10.10 \mathrm{~K} / \mathrm{min}$ temperature calibration curve for Pt furnace using chrome nickel steel DSC crucible.

Figure $11.2 \mathrm{~K} / \mathrm{min}$ temperature calibration curve for Pt furnace using chrome nickel steel DSC crucible.

Figure $12.10 \mathrm{~K} / \mathrm{min}$ sensitivity calibration curve for Pt furnace using chrome nickel steel DSC crucible.

Figure $13.2 \mathrm{~K} / \mathrm{min}$ sensitivity calibration curve for Pt furnace using chrome nickel steel DSC crucible. 12

Figure 14. LiCl-KCl phase diagram based off DSC experimental results. ............................................... 14

Figure 15. LiCl-KCl phase diagram comparing other studies with this study......................................... 14

Figure 16. Comparison of Mk-IV salt before and after FFTF fuel. ......................................................... 17

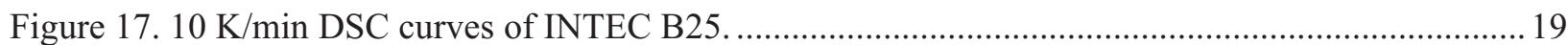

Figure 18. Comparison of thermograms for B25-1 and B25-2 (cycle 2) at $10 \mathrm{~K} / \mathrm{min}$...........................2 20 


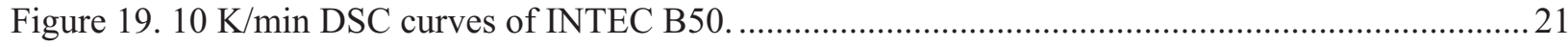

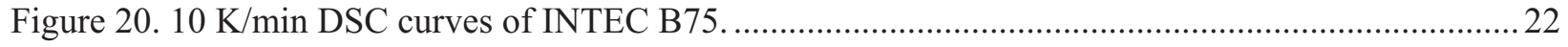

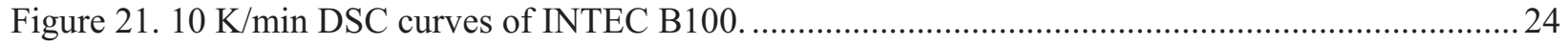

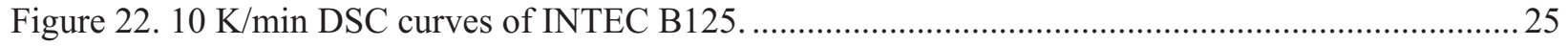

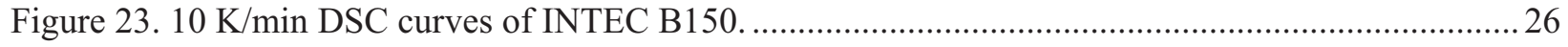

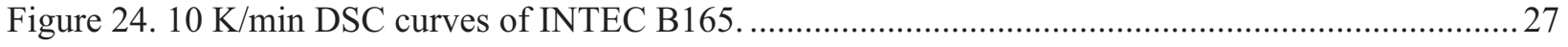

Figure 25. Liquidus and onset temperature as a function of impurity concentration in simulated

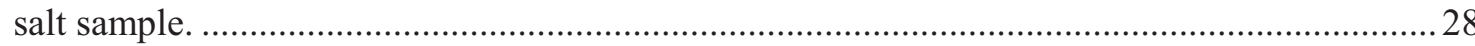

Figure 26. Glovebox ready Netzsch STA 449 F3 instrument................................................................ 30

Figure B-1. $10 \mathrm{~K} / \mathrm{min}$ heating rate for the Benzoic Acid standard. ..................................................... 40

Figure B-2. $2 \mathrm{~K} / \mathrm{min}$ heating rate for the Benzoic Acid standard. .......................................................... 40

Figure B-3. $10 \mathrm{~K} / \mathrm{min}$ heating rate for the Rubidium Nitrate standard. ................................................. 41

Figure B-4. $2 \mathrm{~K} / \mathrm{min}$ heating rate for the Rubidium Nitrate standard. ................................................... 41

Figure B-5. $10 \mathrm{~K} / \mathrm{min}$ heating rate for the Potassium Perchlorate standard............................................ 42

Figure B-6. $2 \mathrm{~K} / \mathrm{min}$ heating rate for the Potassium Perchlorate standard............................................. 42

Figure B-7. $10 \mathrm{~K} / \mathrm{min}$ heating rate for the Cesium Chloride standard..................................................4 43

Figure B-8. $2 \mathrm{~K} / \mathrm{min}$ heating rate for the Cesium Chloride standard.................................................... 43

Figure $\mathrm{C}-1$. DSC curve for $\mathrm{LiCl}-\mathrm{KCl}$ sample $1(0 \mathrm{wt} \% \mathrm{LiCl})$ with $2 \mathrm{~K} / \mathrm{min}$ heating rate....................... 47

Figure C-2. DSC curve for $\mathrm{LiCl}-\mathrm{KCl}$ sample $2(20 \mathrm{wt} \% \mathrm{LiCl})$ with $2 \mathrm{~K} / \mathrm{min}$ heating rate..................... 47

Figure C-3. DSC curve for $\mathrm{LiCl}-\mathrm{KCl}$ sample 3 (44 wt $\% \mathrm{LiCl}$ ) with $2 \mathrm{~K} / \mathrm{min}$ heating rate...................... 48

Figure C-4. DSC curve for $\mathrm{LiCl}-\mathrm{KCl}$ sample $4(40 \mathrm{wt} \% \mathrm{LiCl})$ with $2 \mathrm{~K} / \mathrm{min}$ heating rate..................... 48

Figure C-5. DSC curve for LiCl-KCl sample $5(80 \mathrm{wt} \% \mathrm{LiCl})$ with $2 \mathrm{~K} / \mathrm{min}$ heating rate. ...................... 49

Figure C-6. DSC curve for $\mathrm{LiCl}-\mathrm{KCl}$ sample $6(100 \mathrm{wt} \% \mathrm{LiCl})$ with $2 \mathrm{~K} / \mathrm{min}$ heating rate. .................... 49

Figure C-7. DSC curve for $\mathrm{LiCl}-\mathrm{KCl}$ sample $7(56.4 \mathrm{wt} \% \mathrm{LiCl})$ with $2 \mathrm{~K} / \mathrm{min}$ heating rate....................50

Figure C-8. DSC curve for $\mathrm{LiCl}-\mathrm{KCl}$ sample $8(7.5 \mathrm{wt} \% \mathrm{LiCl}) \mathrm{with} 2 \mathrm{~K} / \mathrm{min}$ heating rate.....................50

Figure C-9. DSC curve for $\mathrm{LiCl}-\mathrm{KCl}$ sample $1(0 \mathrm{wt} \% \mathrm{LiCl})$ with $10 \mathrm{~K} / \mathrm{min}$ heating rate...................... 52

Figure C-10. DSC curve for $\mathrm{LiCl}-\mathrm{KCl}$ sample $2(20 \mathrm{wt} \% \mathrm{LiCl})$ with $10 \mathrm{~K} / \mathrm{min}$ heating rate...................5 52

Figure C-11. DSC curve for $\mathrm{LiCl}-\mathrm{KCl}$ sample $3(44 \mathrm{wt} \% \mathrm{LiCl})$ with $10 \mathrm{~K} / \mathrm{min}$ heating rate...................53

Figure C-12. DSC curve for $\mathrm{LiCl}-\mathrm{KCl}$ sample $4(40 \mathrm{wt} \% \mathrm{LiCl})$ with $10 \mathrm{~K} / \mathrm{min}$ heating rate................... 53

Figure C-13. DSC curve for $\mathrm{LiCl}-\mathrm{KCl}$ sample $5(80 \mathrm{wt} \% \mathrm{LiCl})$ with $10 \mathrm{~K} / \mathrm{min}$ heating rate...................5 54

Figure C-14. DSC curve for $\mathrm{LiCl}-\mathrm{KCl}$ sample $6(100 \mathrm{wt} \% \mathrm{LiCl})$ with $10 \mathrm{~K} / \mathrm{min}$ heating rate..................54

Figure C-15. DSC curve for $\mathrm{LiCl}-\mathrm{KCl}$ sample $7(56.4 \mathrm{wt} \% \mathrm{LiCl})$ with $10 \mathrm{~K} / \mathrm{min}$ heating rate................55

Figure C-16. DSC curve for $\mathrm{LiCl}-\mathrm{KCl}$ sample $8(7.5 \mathrm{wt} \% \mathrm{LiCl})$ with $10 \mathrm{~K} / \mathrm{min}$ heating rate..................55

Figure D-1. DSC curve for before FFTF, $76.83 \mathrm{wt} \% \mathrm{LiCl}-\mathrm{KCl}$ with $2 \mathrm{~K} / \mathrm{min}$ heating rate......................59

Figure D-2. DSC curve for before FFTF, $76.83 \mathrm{wt} \% \mathrm{LiCl}-\mathrm{KCl}$ with $10 \mathrm{~K} / \mathrm{min}$ heating rate....................59 
Figure D-3. DSC curve for after FFTF, $70.39 \mathrm{wt} \% \mathrm{LiCl}-\mathrm{KCl}$ with $2 \mathrm{~K} / \mathrm{min}$ heating rate........................ 60

Figure D-4. DSC curve for after FFTF, $70.39 \mathrm{wt} \% \mathrm{LiCl}-\mathrm{KCl}$ with $10 \mathrm{~K} / \mathrm{min}$ heating rate...................... 60

Figure D-5. DSC curves comparing before FFTF with After FFTF, 2 K/min heating rate...................... 61

Figure D-6. DSC curves comparing before FFTF with After FFTF, $10 \mathrm{~K} / \mathrm{min}$ heating rate....................61

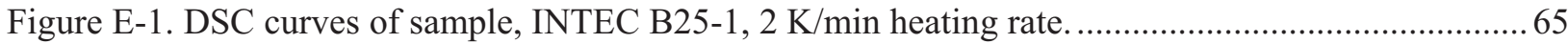

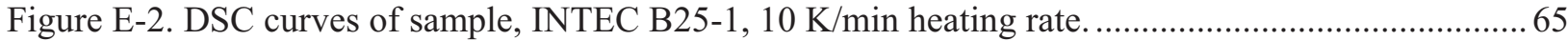

Figure E-3. DSC curves of sample, INTEC B25-2, $2 \mathrm{~K} / \mathrm{min}$ heating rate ............................................6

Figure E-4. DSC curves of sample, INTEC B25-2, 10/min heating rate ............................................6 66

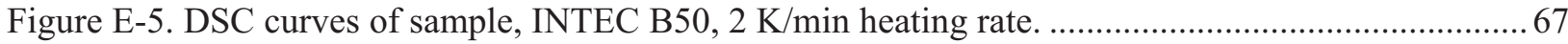

Figure E-6. DSC curves of sample, INTEC B50, $10 \mathrm{~K} / \mathrm{min}$ heating rate. ...........................................67

Figure E-7. DSC curves of sample, INTEC B75, $2 \mathrm{~K} / \mathrm{min}$ heating rate .............................................6 68

Figure E-8. DSC curves of sample, INTEC B75, $10 \mathrm{~K} / \mathrm{min}$ heating rate. ...........................................6 68

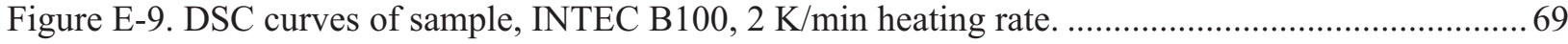

Figure E-10. DSC curves of sample, INTEC B100, $10 \mathrm{~K} / \mathrm{min}$ heating rate. ..........................................69

Figure E-11. DSC curves of sample, INTEC B125, 2 K/min heating rate. ….................................... 70

Figure E-12. DSC curves of sample, INTEC B125, $10 \mathrm{~K} / \mathrm{min}$ heating rate. ....................................... 70

Figure E-13. DSC curves of sample, INTEC B150, 2 K/min heating rate. …...................................... 71

Figure E-14. DSC curves of sample, INTEC B150, $10 \mathrm{~K} / \mathrm{min}$ heating rate. ......................................... 71

Figure E-15. DSC curves of sample, INTEC B165, 2 K/min heating rate ........................................... 72

Figure E-16. DSC curves of sample, INTEC B165, $10 \mathrm{~K} / \mathrm{min}$ heating rate. ......................................... 72

\section{TABLES}

Table 1. List of salts used in this study. 3

Table 2. Composition of Mk-IV salt and $15 \mathrm{~g}$ simulated sample after batch 25 of INTEC fuel was

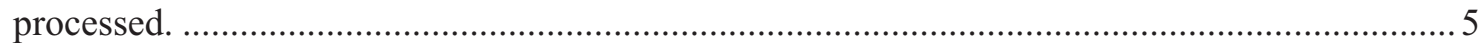

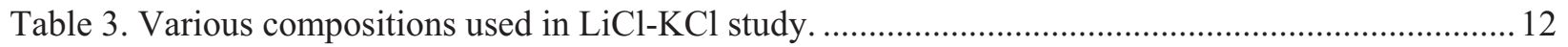

Table 4: Eutectic and Liquidus temperatures for LiCl-KCl study ...................................................... 13

Table 5. Composition of Mk-IV salt before and after FFTF fuel processing. .......................................... 16

Table 6. Onset and liquidus temperature before and after FFTF fuel processing.................................. 17

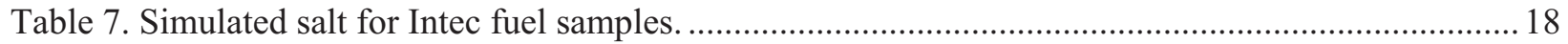

Table 8. Onset and liquidus temperatures at multiple heating rates for INTEC B25 .............................. 19

Table 9. Onset and liquidus temperatures of INTEC B25-1 and B25-2 .............................................20

Table 10. Onset and liquidus temperatures at multiple heating rates for INTEC B50.............................22

Table 11. Onset and liquidus temperatures at multiple heating rates for INTEC B75 ............................23

Table 12. Onset and liquidus temperatures at multiple heating rates for INTEC B100..........................24 
Table 13. Onset and liquidus temperatures at multiple heating rates for INTEC B125.........................25

Table 14. Onset and liquidus temperatures at multiple heating rates for INTEC B150_........................26

Table 15. Onset and liquidus temperatures at multiple heating rates for INTEC B165 ..........................2

Table A-1. Composition of Mk-IV salt and $15 \mathrm{~g}$ surrogate sample before FFTF fuel processing. ............ 34

Table A-2. Composition of Mk-IV salt and $15 \mathrm{~g}$ surrogate sample after FFTF fuel processing. ...............34

Table A-3. Composition of Mk-IV salt and 15 g surrogate sample after INTEC B25.............................35

Table A-4: Composition of Mk-IV salt and $15 \mathrm{~g}$ surrogate sample after INTEC B50 ............................35

Table A-5. Composition of Mk-IV salt and $15 \mathrm{~g}$ surrogate sample after INTEC B75 ...........................36

Table A-6. Composition of Mk-IV salt and $15 \mathrm{~g}$ surrogate sample after INTEC B100 .........................36

Table A-7. Composition of Mk-IV salt and $15 \mathrm{~g}$ surrogate sample after INTEC B125 .......................... 37

Table A-8: Composition of Mk-IV salt and $15 \mathrm{~g}$ surrogate sample after INTEC B150 .......................... 37

Table B-1. Onset and Peak values obtained from thermograms in Figure B-1 and B-2 ........................ 40

Table B-2. Onset and Peak values obtained from thermograms in Figure B-3 and B-4........................ 41

Table B-3. Onset and Peak values obtained from thermograms in Figure B-5 and B-6........................ 42

Table B-4. Onset and Peak values obtained from thermograms in Figure B-7 and B-8 ......................... 43

Table B-5. Onset and Peak values obtained from thermograms in Figure B-9 and B-10....................... 44

Table C-1. Summary of results taken from Figure C-1 through Figure CB-8 ...................................51

Table C-2. Summary of results taken from Figure C-9 through Figure C-16 ........................................ 56 


\section{ACRONYMS}

\begin{tabular}{ll} 
DI & Deionized \\
DSC & Differential Scanning Calorimetry \\
EBR-II & Experimental Breeder Reactor II \\
ER & Electrorefiner \\
FFTF & Fast Flux Test Facility \\
FP & Fission Product \\
Fs & Fissium (an alloy of Y, Zr, Mo, Ru, Rh, and Pd) \\
g & gram \\
INTEC & Idaho Nuclear Technology and Engineering Center \\
kg & kilogram \\
LiCl-KCl & Lithium Chloride - Potassium Chloride \\
Me & Metal \\
MeClx & Metal Chloride \\
MFC & Materials and Fuels Complex \\
mol\% & Molecular Percentage \\
MW & Molecular Weight \\
ppm & parts per million \\
RCRA & Resource Conservation and Recovery Act \\
RT & Room Temperature \\
STA & Simultaneous Thermal Analysis \\
TGA & Thermogravimetric Analysis \\
TRU & Transuranic \\
WCL & Water Chemistry Laboratory \\
wt & weight pent \\
\hline &
\end{tabular}





\section{THERMAL CHARACTERIZATION OF MOLTEN SALT SYSTEMS}

\section{INTRODUCTION}

This project is a fundamental study to measure the liquidus temperatures of molten salt systems typical of uranium electrorefining operations to determine the thermal properties of the molten salt electrolyte as a function of its composition. The objective is to identify the thermal properties of salt under different conditions and provide a better understanding of how salt will behave as the impurity load increases during electrorefining operations. Because the thermal characteristics of salt are functions of impurity concentration in the ER electrolyte, the stability and homogeneity of each phase can potentially be monitored through the salt's thermal characteristics.

Potential situations that need to be avoided are the following: (1) salt freezing due to an unexpected change in the liquidus temperature, (2) phase separation or non-homogeneity of the molten salt due to the precipitation of solids or formation of immiscible liquids, and (3) any mechanism that can result in the separation and concentration of fissile elements from the molten salt. Any of these situations would result in an off-normal condition outside the established safety basis for electrorefiner (ER) operations.

The focus for this study is the analysis of salt in the Mk-IV ER when processing used nuclear fuel from the Fast Flux Test Facility (FFTF) U-10Zr fuel or the Experimental Breeder Reactor II (EBR-II) U-5Fs fuel. The EBR-II fuel of interest here is the so called "fissium (Fs)" fuel presently located at the Idaho Nuclear Technology and Engineering Center (INTEC). As FFTF and INTEC fuel is processed in the Mk-IV ER, the impurity concentration increases in the salt. The major metal chlorides present in the electrolyte include the following:

1. Eutectic Salt: LiCl-KCl eutectic

2. Actinides: Uranium, Plutonium, Neptunium

3. Active Metal Fission Products: Strontium, Cesium, Barium, Lanthanum, Cerium, Praseodymium, Neodymium, Samarium

4. Bond Sodium: Sodium

Figure 1 shows the buildup of metal chlorides in the salt versus kilograms $(\mathrm{kg})$ of uranium processed. The initial or base electrolyte is $\mathrm{LiCl}-\mathrm{KCl}-\mathrm{UCl}_{3}$. The dark lines of each color represent the weight percent (wt $\%$ ) of sodium, transuranic (TRU), and fission product (FP) chlorides built-up in the salt prior to FFTF and INTEC fuel processing. The lighter sections of each line show the increasing $\mathrm{wt} \% \mathrm{of} \mathrm{Na}$, TRU, and FP chlorides as FFTF and INTEC fuel are processed. LiCl-KCl concentration is based on information provided by References 1 and 2. This data was decayed to 01/01/2011 using Eigen-Value decomposition techniques.

Over $312 \mathrm{~kg}$ of FFTF and 1,976 kg of INTEC heavy metal fuel will be processed (Ref. 1). For this study nine samples will be prepared, two samples to simulate the electrolyte during FFTF fuel processing and seven samples to simulate the electrolyte as INTEC fuel is processed. Each sample will have a varying composition of impurity elements, in order to accurately represent the electrolyte during fuel processing. Target impurities being studied are uranium, plutonium, fission products ( $\mathrm{Sr}, \mathrm{Sm}, \mathrm{Pr}, \mathrm{La}, \mathrm{Ba}, \mathrm{Ce}, \mathrm{Cs}$, and $\mathrm{Nd}$ ) and Sodium. These impurities, along with the LiCl-KCl electrolyte, represent $\sim 99 \%$ of the salt in the Mk-IV ER. Gadolinium will be used as a surrogate for uranium and plutonium to keep the experiments non-radiological. Strontium will be used in the place of barium since barium is a Resource Conservation and Recovery Act (RCRA) metal, which would make the disposal of wastes more difficult. 


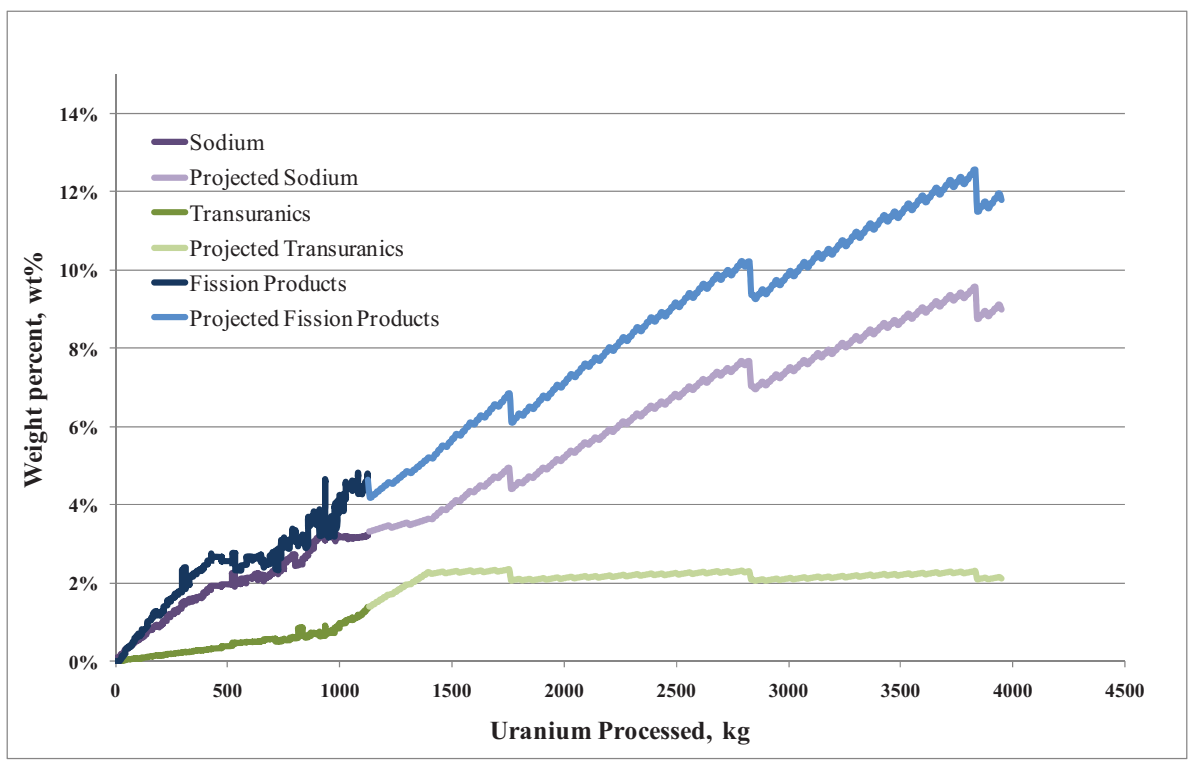

Figure 1. Mk-IV salt composition vs. uranium processed.

The thermal properties of molten salt in an electrorefiner (ER) are affected by the buildup of FP, TRU, and bond-sodium. By knowing how the liquidus temperature increases with fuel processing and impurity buildup, ER operators can better determine when the salt has reached its useful life. The ER currently operates at $500^{\circ} \mathrm{C}$ and, at this temperature, the electrolyte with the current impurties is a homogenous melt. But as will be seen from the results of this study, there is a point at which the salt in the ER will no longer be a homogenous melt due to plutonium, FP, and sodium buildup. The buildup will have a number of effects on ER operations.

\section{EXPERIMENTAL SETUP}

This research was performed in the Water Chemistry Laboratory (WCL), Building 768B, at the Materials \& Fuels Complex (MFC). The lab provided the necessary equipment and chemicals needed to perform the research. All sample preparation was performed in a MBraun glovebox, pictured in Figure 2, that has the capability of maintaining moisture and oxygen concentrations below 0.1 parts per million (ppm) and has an inert argon atmosphere. While work was being performed in the glovebox, the oxygen and moisture concentrations remained below $0.1 \mathrm{ppm}$ unless otherwise noted.

The chemicals used in this research had a purity of $99.99 \%$ or greater except for samarium chloride $\left(\mathrm{SmCl}_{3}\right)$ which had a purity of $99.9 \%$. All chemicals were ordered from Sigma Aldrich or Alfa Aesar and were packaged under an argon atmosphere in sealed glass ampoules. Once received the ampoules were immediately placed in the glovebox. A diamond file was used to score the outside of the ampoule, and the chemical contents were pace in a labeled glass vial. All salts were stored in the glovebox because they were hygroscopic. The ten chloride salts used for the simulation experiments (plus $\mathrm{KCl}$ ) are listed in Table 1. 


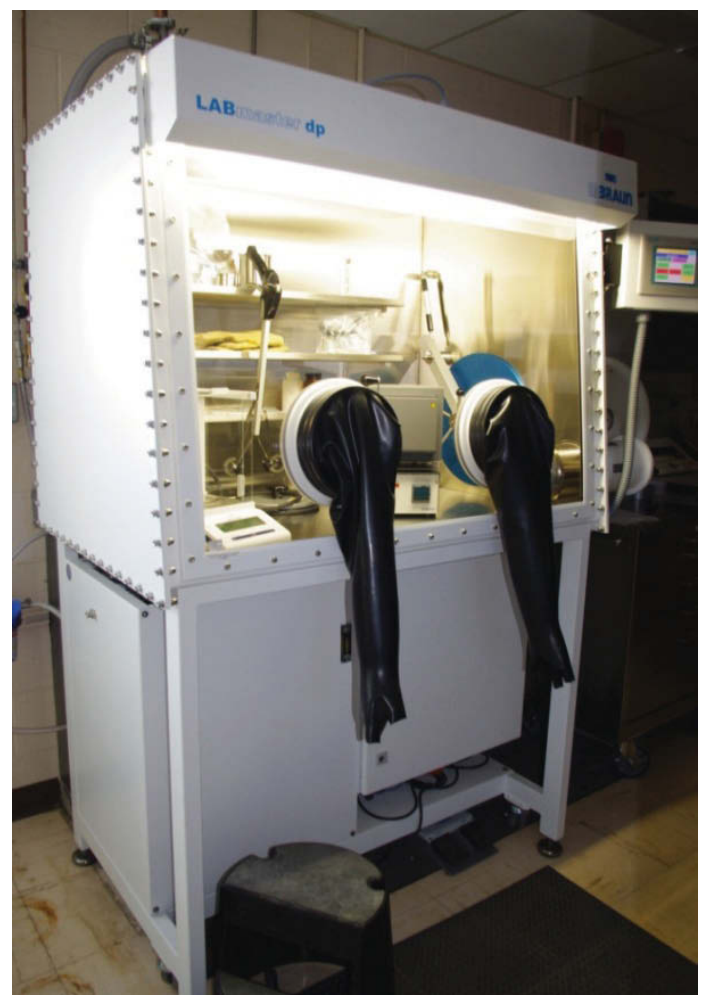

Figure 2. Argon atmosphere, moisture and oxygen controlled glovebox located in WCL.

Table 1. List of salts used in this study.

\begin{tabular}{|c|c|c|c|c|c|c|c|}
\hline Chemical Name & $\begin{array}{c}\text { Chemical } \\
\text { Formula } \\
\end{array}$ & Supplier & Purity & $\begin{array}{c}\text { Product } \\
\#\end{array}$ & Lot \# & CAS \# & Comments \\
\hline $\begin{array}{l}\text { Cerium (III) } \\
\text { Chloride }\end{array}$ & $\mathrm{CeCl}_{3}$ & $\begin{array}{l}\text { Sigma } \\
\text { Aldrich }\end{array}$ & $\geq 99.99 \%$ & 429206 & MKBB9297 & $7790-86-5$ & $\begin{array}{l}\text { Anhydrous } \\
\text { Beads, } 10 \text { mesh }\end{array}$ \\
\hline Cesium Chloride & $\mathrm{CsCl}$ & $\begin{array}{l}\text { Sigma } \\
\text { Aldrich }\end{array}$ & $99.99 \%$ & 449733 & 11991BR & $7647-17-8$ & $\begin{array}{l}\text { Anhydrous } \\
\text { Beads, } 10 \text { mesh }\end{array}$ \\
\hline $\begin{array}{l}\text { Gadolinium (III) } \\
\text { Chloride }\end{array}$ & $\mathrm{GdCl}_{3}$ & $\begin{array}{l}\text { Sigma } \\
\text { Aldrich }\end{array}$ & $99.99 \%$ & 439770 & K26W158 & $10138-52-0$ & Anhydrous \\
\hline $\begin{array}{l}\text { Lanthanum (III) } \\
\text { Chloride }\end{array}$ & $\mathrm{LaCl}_{3}$ & $\begin{array}{l}\text { Alfa } \\
\text { Aesar }\end{array}$ & $99.999 \%$ & 44322 & L08N13 & $10099-58-8$ & Ultra Dry Powder \\
\hline $\begin{array}{l}\text { Lithium Chloride/ } \\
\text { Potassium Chloride }\end{array}$ & $\mathrm{LiCl}-\mathrm{KCl}$ & $\begin{array}{l}\text { Sigma } \\
\text { Aldrich }\end{array}$ & $99.99 \%$ & 479330 & MKBC8337 & $65567-96-6$ & Anhydrous Beads \\
\hline $\begin{array}{l}\text { Neodymium (III) } \\
\text { Chloride }\end{array}$ & $\mathrm{NdCl}_{3}$ & $\begin{array}{l}\text { Sigma } \\
\text { Aldrich }\end{array}$ & $\geq 99.99 \%$ & 449946 & MKBB6345 & $10024-93-8$ & $\begin{array}{l}\text { Anhydrous } \\
\text { Powder }\end{array}$ \\
\hline Potassium Chloride & $\mathrm{KCl}$ & $\begin{array}{l}\text { Sigma } \\
\text { Aldrich } \\
\end{array}$ & 99.999 & 449989 & & $7447-40-7$ & $\begin{array}{l}\text { Anhydrous } \\
\text { Beads, } 10 \text { mesh } \\
\end{array}$ \\
\hline $\begin{array}{l}\text { Praseodymium (III) } \\
\text { Chloride }\end{array}$ & $\mathrm{PrCl}_{3}$ & $\begin{array}{l}\text { Sigma } \\
\text { Aldrich }\end{array}$ & $99.99 \%$ & 298298 & 99096MJ & $10361-79-2$ & $\begin{array}{l}\text { Anhydrous } \\
\text { Powder }\end{array}$ \\
\hline $\begin{array}{l}\text { Samarium (III) } \\
\text { Chloride }\end{array}$ & $\mathrm{SmCl}_{3}$ & $\begin{array}{l}\text { Alfa } \\
\text { Aesar }\end{array}$ & $99.9 \%$ & 35804 & A15T006 & $10361-82-7$ & Ultra Dry Powder \\
\hline Sodium Chloride & $\mathrm{NaCl}$ & $\begin{array}{l}\text { Sigma } \\
\text { Aldrich }\end{array}$ & $99.999 \%$ & 450006 & MKBF6003V & $7647-14-5$ & Anhydrous Beads \\
\hline $\begin{array}{l}\text { Strontium (II) } \\
\text { Chloride }\end{array}$ & $\mathrm{SrCl}_{2}$ & $\begin{array}{l}\text { Sigma } \\
\text { Aldrich }\end{array}$ & $\geq 99.99 \%$ & 439665 & MKBC8344 & $10476-85-4$ & $\begin{array}{l}\text { Anhydrous } \\
\text { Powder }\end{array}$ \\
\hline
\end{tabular}


The experimental setup procedure involved several steps: (1) calculations, (2) measuring and melting, (3) homogenization, and (4) Differential Scanning Calorimetry (DSC) analysis. A total of eight simulated samples were prepared for this study. These samples simulated the electrolyte in the Mk-IV ER at set points during FFTF and INTEC fuel processing. Two samples represent the salt during FFTF processing, and seven samples represent the salt during INTEC fuel processing.

During sample preparation each of the ten chloride salts used were weighed into a plastic weighing dish and weighed to the nearest $0.0001 \mathrm{~g}$ using a Mettler Toledo Analytical Balance model number MS3045/03. The analytical balance was calibrated, had an accuracy of $\pm 0.0005 \mathrm{~g}$, and was periodically auto calibrated. A $1.0000 \mathrm{~g}$ standard was used daily to make sure the balance was operating within the calibrated accuracy. The measured values of the $1.0000 \mathrm{~g}$ standard were within $\pm 0.0003 \mathrm{~g}$.

Salts were blended and heated in a $30 \mathrm{~mL}$ high form nickel (Ni) crucible with Ni lid. The Ni crucible was heated to $500^{\circ} \mathrm{C}$ in a Thermo Scientific small bench top muffle furnace. The chloride salts showed no sign of reaction with the Ni crucible when heated in the furnace. An agate mortar and pestle was used to grind and reduce the particle size of the recrystallized salt.

\subsection{Calculations}

There are about $500 \mathrm{~kg}$ of electrolyte in the Mk-IV ER. This study used a 15-g surrogate sample to simulate this $500-\mathrm{kg}$ inventory. More than $99 \mathrm{wt} \%$ of the ER salt was represented using chlorides of Li, $\mathrm{K}, \mathrm{Na}, \mathrm{Nd}, \mathrm{U}, \mathrm{Pu}, \mathrm{Cs}, \mathrm{Ce}, \mathrm{La}, \mathrm{Pr}, \mathrm{Sm}, \mathrm{Ba}$, and Sr. Weighted atomic masses for the top fourteen elements (including $\mathrm{Cl}$ ) in the salt were calculated based on (a combination of measured and modeled) isotopic abundances in the Mk-IV salt. And these weighted atomic masses were used to calculate the weight percent of each element in the salt.

The weight percentages of the top fourteen elements present in the Mk-IV ER electrolyte were used to calculate the amount of each metal chloride needed to make the 15-g simulation sample used for DSC analysis. The 15 -g simulation sample contains the same elements and in the same $\mathrm{wt} \%$ as the original Mk-IV salt composition from which the simulation sample is based. To keep this research non-radiological and RCRA metal free, $\mathrm{Gd}$ is used in place of $\mathrm{U}$ and $\mathrm{Pu}$ and $\mathrm{Sr}$ is used in place of $\mathrm{Ba}$.

The elements present in the Mk-IV ER salt after batch 25 of INTEC fuel (INTEC B25) has been processed is shown in Table 2. The element present in the salt at the highest concentration has a rank of 1; chlorine $(\mathrm{Cl})$ is the most abundant, potassium $(\mathrm{K})$ is the second most abundant, etc. In equation 1, the $\mathrm{wt} \%$ of metal $(\mathrm{Me})$ in the salt is calculated for $\mathrm{K}$ :

$$
\frac{\text { Weight of } M e(g) \text { in salt }}{\text { Total salt weight }(g)}=\frac{84430.8 \mathrm{~g}}{444250.0 \mathrm{~g}} \times 1100=45.35 \mathrm{wt} \% \mathrm{~K} \quad(\text { eq } 1)
$$

The molecular weight (MW) of Me is calculated based on different element isotopes and their abundance in the Mk-IV ER. Li, K, $\mathrm{Na}$ and $\mathrm{Cs}$ are assumed to be in a +1 oxidation state; $\mathrm{Ba}$ and $\mathrm{Sr}$ in the +2 oxidation state; and $\mathrm{Nd}, \mathrm{U}, \mathrm{Pu}, \mathrm{Ce}, \mathrm{La}, \mathrm{Pr}, \mathrm{Sm}$ are present in the salt in the +3 oxidation state. Equation 2 shows the calculations for determining the amount of metal chloride $\left(\mathrm{MeCl}_{\mathrm{x}}\right)$, in this case $\mathrm{KCl}$, needed to make a $15 \mathrm{~g}$ surrogate sample. The subscript $\mathrm{x}$, in $\mathrm{MeCl}_{\mathrm{x}}$ represents the number of chloride ions needed to balance the valence of the metal cation.

$$
15 \mathrm{~g} \mathrm{MeCl}_{x} \text { Sample }=\frac{\left[\left(\frac{M W \text { of } M e C l_{x}}{M W \text { of } M e}\right) \cdot \text { wt of Me in salt }\right]}{\sum\left[\left(\frac{M W \text { of } M e C l_{x}}{M W \text { of } M e}\right) \cdot \text { wt of Me in salt }\right]} \times 15 \text { grams (eq 2) }
$$




$$
\begin{aligned}
& {\left[\left(\frac{74.25 \frac{g K C l}{\mathrm{~mol} \mathrm{KCl}}}{39.06 \frac{\mathrm{gK}}{\mathrm{mol} \mathrm{K}}}\right) \cdot 84,431 \mathrm{~g} \mathrm{~K} \text { in salt }\right]}
\end{aligned}
$$

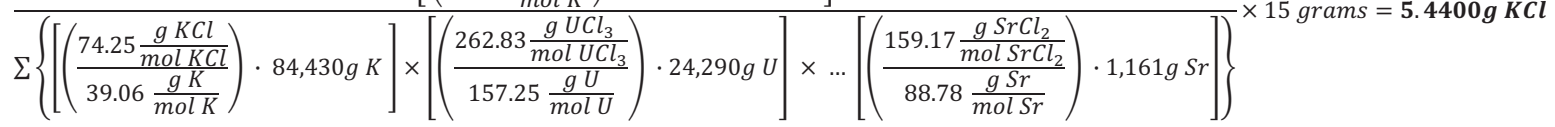

In Table 2 the columns with the word "actual" are based on a real, prepared simulated salt sample. The weights used are in the form of grams $(\mathrm{g})$ of $\mathrm{MeCl}_{\mathrm{x}}$. For example, $1.6851 \mathrm{~g}$ of $\mathrm{NaCl}$ was used in the $15 \mathrm{~g}$ sample to represent the $\mathrm{wt} \%$ of Na present in the Mk-IV ER. Table 2 shows that the ER salt contains $10.55 \mathrm{wt} \% \mathrm{Na}$, the $15 \mathrm{~g}$ simulated salt sample also contains $10.55 \mathrm{wt} \% \mathrm{Na}$. This can be checked using the values in the column, actual wt of Me in $15 \mathrm{~g}$ sample, and applying the values to Equation 1.

The MW weight of $\mathrm{Gd}$ is used instead of $\mathrm{U}$ because $\mathrm{GdCl}_{3}$ is substituted for $\mathrm{UCl}_{3}$ so that the sample is non-radiological. The same concept applies for $\mathrm{PuCl}_{3}$. Nonetheless, the final sample contains the same wt $\%$ of each element as the original Mk-IV ER electrolyte it was modeled after. This can be verified by comparing the columns titled: wt $\%$ Me in ER salt and actual wt $\%$ Me in $15 \mathrm{~g}$ sample. Equation 3 shows the equation used to calculate the actual $\mathrm{wt} \%$ of Me in $15 \mathrm{~g}$ sample.

$$
w t \% \text { of Me in } 15 \mathrm{~g} \text { Sample }=\frac{\left[\left(\frac{M W \text { of } M e}{M W \text { of } M e C l_{x}}\right) \cdot \text { wt of Me in } 15 \mathrm{~g} \text { Sample }\right]}{\sum\left[\left(\frac{M W \text { of } M e}{M W \text { of } M e C l_{x}}\right) \cdot w t \text { of Me in } 15 \mathrm{~g} \text { Sample }\right]} \times 100 \text { (eq 3) }
$$

The wt $\%$ of metal in the Mk-IV salt and the wt $\%$ of Me in the $15 \mathrm{~g}$ sample should be similar if not exactly the same. This can be seen by comparing the wt $\%$ Me in salt column to the actual $\mathrm{wt} \% \mathrm{Me}$ in $15 \mathrm{~g}$ sample column in Table 2.

Table 2. Composition of Mk-IV salt and $15 \mathrm{~g}$ simulated sample after batch 25 of INTEC fuel was processed.

\begin{tabular}{|c|l|c|c|c|c|c|c|}
\hline $\begin{array}{c}\text { INTEC } \\
\text { B25 } \\
\text { Rank }\end{array}$ & \multicolumn{1}{|c|}{ Element } & $\begin{array}{c}\text { wt of Me in } \\
\text { ER salt }\end{array}$ & $\begin{array}{c}\text { wt\% Me in } \\
\text { ER salt }\end{array}$ & $\begin{array}{c}15 \mathrm{~g} \\
\text { MeClx } \\
\text { Sample }\end{array}$ & $\begin{array}{c}\text { Actual wt } \\
\text { of MeCl } \text { in } \\
15 \mathrm{~g} \\
\text { Sample }\end{array}$ & $\begin{array}{c}\text { Actual wt } \\
\text { of Me in } \\
15 \mathrm{~g} \\
\text { Sample }\end{array}$ & $\begin{array}{c}\text { Actual wt\% } \\
\text { Me in 15 g } \\
\text { sample }\end{array}$ \\
\hline 1 & Chlorine & 258091.64 & & & & & \\
\hline 2 & Potassium & 84430.76 & $45.35 \%$ & 5.4400 & 5.4400 & 2.8617 & $45.36 \%$ \\
\hline 3 & Uranium (Gd) & 24290.26 & $13.05 \%$ & 1.3760 & 1.3760 & 0.8233 & $13.05 \%$ \\
\hline 4 & Lithium & 21869.15 & $11.75 \%$ & 4.4871 & 4.4869 & 0.7412 & $11.75 \%$ \\
\hline 5 & Sodium & 19641.45 & $10.55 \%$ & 1.6848 & 1.6851 & 0.6658 & $10.55 \%$ \\
\hline 6 & Plutonium $(\mathrm{Gd})$ & 8790.68 & $4.72 \%$ & 0.4980 & 0.4975 & 0.2977 & $4.72 \%$ \\
\hline 7 & Neodymium & 7895.55 & $4.24 \%$ & 0.4629 & 0.4629 & 0.2676 & $4.24 \%$ \\
\hline 8 & Cesium & 5623.95 & $3.02 \%$ & 0.2405 & 0.2404 & 0.1905 & $3.02 \%$ \\
\hline 9 & Cerium & 4373.54 & $2.35 \%$ & 0.2593 & 0.2592 & 0.1482 & $2.35 \%$ \\
\hline 10 & Lanthanum & 2396.38 & $1.29 \%$ & 0.1430 & 0.1434 & 0.0815 & $1.29 \%$ \\
\hline 11 & Praseodymium & 2210.12 & $1.19 \%$ & 0.1310 & 0.1312 & 0.0750 & $1.19 \%$ \\
\hline 12 & Samarium & 1807.37 & $0.97 \%$ & 0.1048 & 0.1044 & 0.0610 & $0.97 \%$ \\
\hline 13 & Barium $(\mathrm{Sr})$ & 1667.78 & $0.90 \%$ & 0.1019 & 0.1019 & 0.0565 & $0.90 \%$ \\
\hline 14 & Strontium & 1161.39 & $0.62 \%$ & 0.0706 & 0.0708 & 0.0395 & $0.63 \%$ \\
\hline Total & & $\mathbf{4 4 4 2 5 0 . 0 1}$ & $\mathbf{1 0 0 . 0 0 \%}$ & $\mathbf{1 5 . 0 0 0 0}$ & $\mathbf{1 4 . 9 9 9 7}$ & $\mathbf{6 . 3 0 9 4}$ & $\mathbf{1 0 0 . 0 0 \%}$ \\
\hline
\end{tabular}


Table 2 was prepared specifically for the simulated salt sample labeled INTEC B25. There are eight other simulated salt samples that used the same procedure and equations to calculate the composition and weights of all MeClx needed to make up the $15 \mathrm{~g}$ simulation sample. Tables for all eight samples can be found in Appendix A.

\subsection{Measuring and Melting}

Measuring and melting involves weighing the metal chloride salts (eutectic $\mathrm{LiCl}-\mathrm{KCl}, \mathrm{GdCl}_{3}, \mathrm{NaCl}$, $\mathrm{NdCl}_{3}, \mathrm{CsCl}, \mathrm{CeCl}_{3}, \mathrm{LaCl}_{3}, \mathrm{PrCl}_{3}, \mathrm{SmCl}_{3}$, and $\mathrm{SrCl}_{2}$ ) used to make the $15 \mathrm{~g}$ simulated salt sample. All handling and weighing of the chloride salts was performed in the atmosphere and moisture controlled glovebox with oxygen and moisture levels below $0.1 \mathrm{ppm}$ (see Figure 1). To avoid contamination with other salts, all glovebox surfaces were wiped down with a clean, terry cloth towel before using the pure anhydrous metal chloride salts. Crucibles, spatulas, and weight dishes were washed with deionized (DI) water, rinsed with propanol, and dried in an oven before each use or between each $15 \mathrm{~g}$ sample preparation.

A total of ten salts $\left(\mathrm{GdCl}_{3}\right.$ in place of $\mathrm{UCl}_{3}$ and $\mathrm{PuCl}_{3}$ and $\mathrm{SrCl}_{2}$ in place of $\left.\mathrm{BaCl}_{2}\right)$ were used to make the $15 \mathrm{~g}$ simulated salt sample. All salts used were anhydrous and of high purity (see Table 1 for salt quality information). Salts were weighted using a calibrated balance with a readability of $0.1 \mathrm{mg}$. The salts were weighed into a plastic weighing dish, combined in a nickel crucible, and mixed together with a spatula. The final weight of the combined salts in the nickel crucible is approximately $15 \mathrm{~g}$. All ten salts are weighed individually, and the weights were recorded in a lab data book. Figure 3 shows all ten metal chloride salts mixed in a Ni crucible.

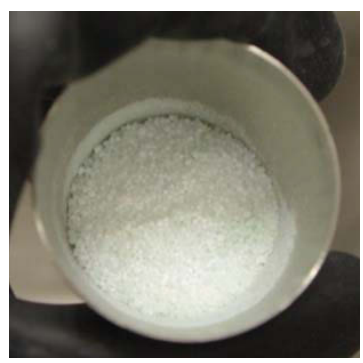

Figure 3. Combined metal chloride salts in Ni crucible.

The nickel crucible with $15 \mathrm{~g}$ of salt mixture and a nickel lid were placed in a furnace at $500^{\circ} \mathrm{C}$ for approximately one hour. At $500^{\circ} \mathrm{C}$ the salt mixture should be completely molten (homogenous) as seen in Figure $4 \mathrm{a}$ for sample INTEC B25. However, this is not always the case. Some of the samples with higher concentrations of impurities, such as sample INTEC B125, appeared not to be completely molten (non-homogenous) at $500^{\circ} \mathrm{C}$, see Figure $4 \mathrm{~b}$. Sample INTEC B25 contained $33.8 \mathrm{wt} \%$ of impurities while sample INTEC B125 contained $51.6 \mathrm{wt} \%$ of impurities in the form of gadolynium, FP's, and sodium. If the sample did not look completely molten at $500^{\circ} \mathrm{C}$, the sample was heated to $600^{\circ} \mathrm{C}$ and held for $1 \mathrm{hr}$.
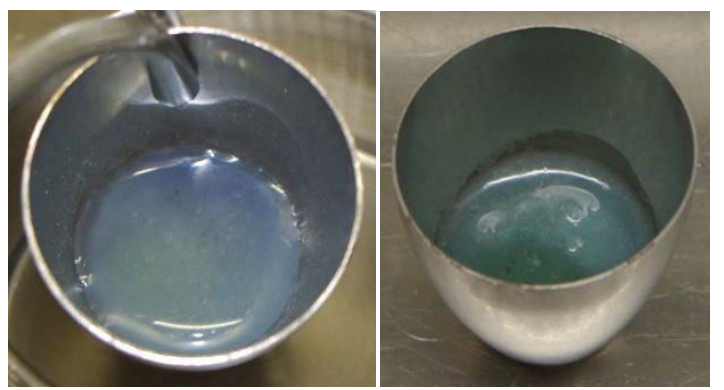

Figures $4 \mathrm{a}$ and $4 \mathrm{~b}$. Homogenous molten salt (INTEC B25) and non-homogenous molten salt (INTEC B125). 
After the crucible and sample were removed from the furnace, the sample was allowed to cool to room temperature (inside glovebox). To reduce the effect of zone cooling, the sample was taken out of the furnace to cool quickly rather than slowly cooling the sample inside the furnace. The effects of zone cooling were reduced but not eliminated as can be seen in Figures $5 \mathrm{a}-5 \mathrm{~d}$, taken of sample INTEC B75. It is clear from Figures $5 \mathrm{a}-5 \mathrm{~d}$ that the molten sample solidifies along the crucible wall first seen most clearly in Figure 5b. The middle then solidifies as seen in Figure 5c until the entire sample has recrystallized into a solid ingot as seen in Figure 5d. It appeared that there was some color variation between the top and bottom of the sample. Color variation can be seen faintly in Figure $5 \mathrm{~d}$, but was noticed on the actual salt ingot.
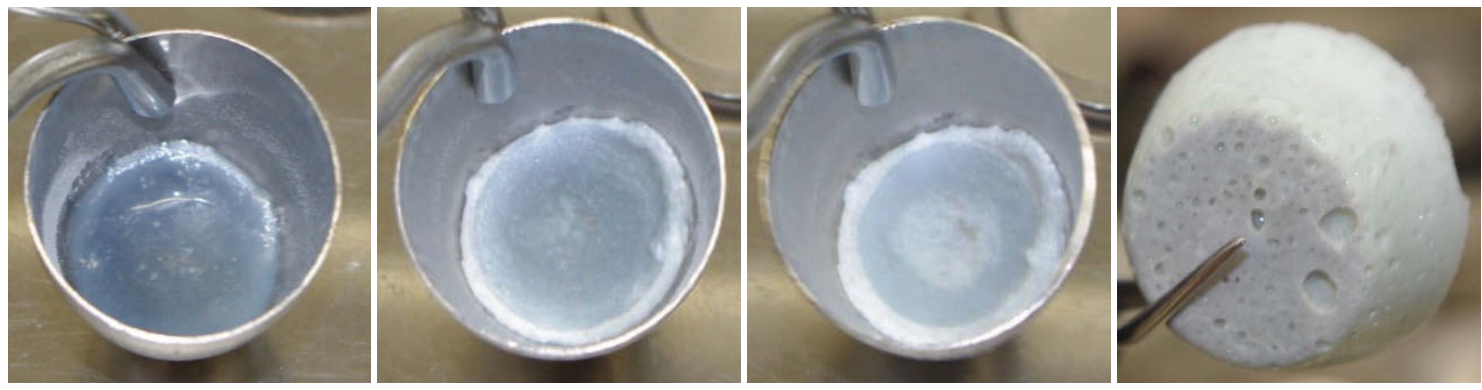

Figure $5 \mathrm{a}-5 \mathrm{~d}$. INTEC B75 as molten sample cools to room temperature.

The most important reason for this experiment to avoid zone freezing is that the final sample needs to be homogenous. As the molten sample cools in the crucible, the composition can vary due to element segregation at different temperatures. Even though the sample should have been homogenous when it was molten, as it cooled and recrystallized the salt sample may have become non-homogenous. This may have been the result because there were possibly regions of higher $\mathrm{LiCl}-\mathrm{KCl}$ concentrations near the edge of the crucible.

\subsection{Homogenization}

Having a homogenous sample ensures that even a minute DSC sample will represent the entire original Mk-IV ER salt sample. There are about $450 \mathrm{~kg}$ of salt in the Mk-IV from this study being represented using a $15 \mathrm{~g}$ simulated sample of the same composition; $15 \mathrm{~g}$ is $0.003 \%$ of $450 \mathrm{~kg}$. From the $15 \mathrm{~g}$ simulated sample, $\sim 10 \mathrm{mg}$ of the sample will be placed in a DSC crucible for analysis. The $10 \mathrm{mg}$ sample is $0.000002 \%$ of $450 \mathrm{~kg}$. Since the DSC uses such a small amount of sample, it is essential to have a homogenous mixture capable of representing the entire original ER electrolyte.

The $15 \mathrm{~g}$ salt ingot (Figure 5d) is not considered a homogenous mass even though it was once a homogenous molten sample in the furnace at temperatures of $500^{\circ} \mathrm{C}$ to $600^{\circ} \mathrm{C}$. From Figure 6 , it is clear the piece of recrystallized salt ingot is not homogenous throughout. This can be seen by the changing color of sample INTEC B75, the top is light blue-green and seems less dense and more brittle than the middle which is a darker shade of light blue; the bottom of the sample is a dark blue-grey color and looks denser than the top of the ingot.

Homogenization of the salt ingot is done by grinding and sieving the crystallized salt ingot with an agate mortar and pestle as seen in Figure 7. The salt is passed through two sieves, US 40 mesh $(0.422 \mathrm{~mm})$ and US 100 mesh $(0.152 \mathrm{~mm})$ yielding a final powder sample with a particle size of $100 \%$ minus 100 mesh. The test sieves were produced and manufactured using methods and quality control procedures to assure conformity according to the ASTM E 11 standard. 


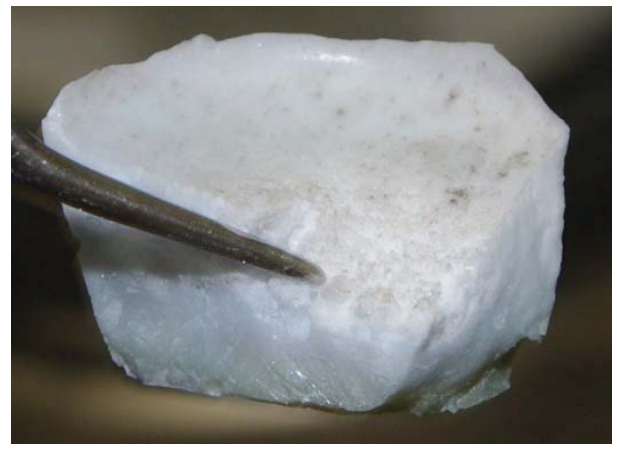

Figure 6. Piece of crystallized salt showing non-homogeneity of $15 \mathrm{~g}$ ingot.

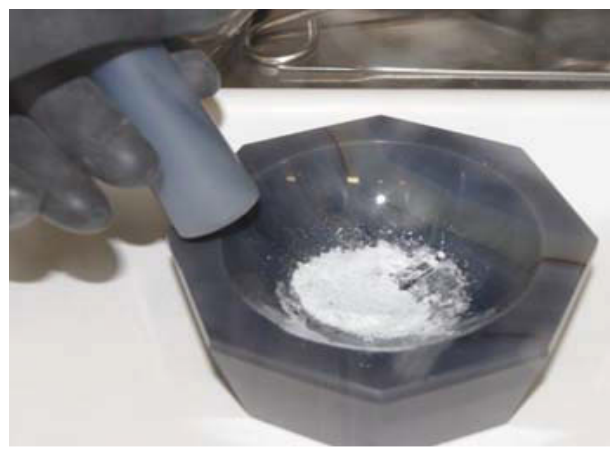

Figure 7. Agate mortar and pestle with crushed salt.

One to three grams of the original $15 \mathrm{~g}$ simulated salt sample was lost during the grinding and sieving process. After the salt sample was ground, it was placed in a labeled glass vial and stored in the glovebox until needed for DSC analysis. The sieves, mortar and pestle, spatulas, weighing dishes, and crucibles were transferred out of the glovebox and cleaned before the next use. Cleaning was done using soap and deionized (DI) water. The clean lab ware was air dried overnight. The grinding and weighing tools were rinsed with propanol to remove any organic residue and baked in an oven to remove any remaining residual water.

\subsection{DSC Analysis}

A Netzsch STA 449 F3 thermal analyzer was used to determine the liquidus temperature of the surrogate samples, see Figure 8. Netzsch is the manufacturer, 449 is the model number, F3 is the series, and STA means simultaneous thermal analysis. Simultaneous implies that the Differential Scanning Calormetry (DSC) and Thermogravimetric Analysis (TGA) can be performed at the same time. Since TGA was not used for this study, the term DSC will be used in this report instead of STA. DSC is the measure of the change of the difference of heat flow rate to the sample and a reference sample while both samples are subjected to a controlled temperature program (Ref. 3 ). It has the capability to measure the heat of a reaction and partial heat levels between specific temperature intervals. Figure 8 shows the DSC setup in the WCL at MFC. The DSC includes two furnaces, argon purge gas, cooler, vacuum, sample carrier and laptop for instrument control and data acquisition and storage. The cooler is used to keep the microbalance within the DSC cool; typically set to $25^{\circ} \mathrm{C}$. The vacuum feature may be used to study samples at lower pressures, but for these studies atmospheric pressure was used and the vacuum was not needed. 


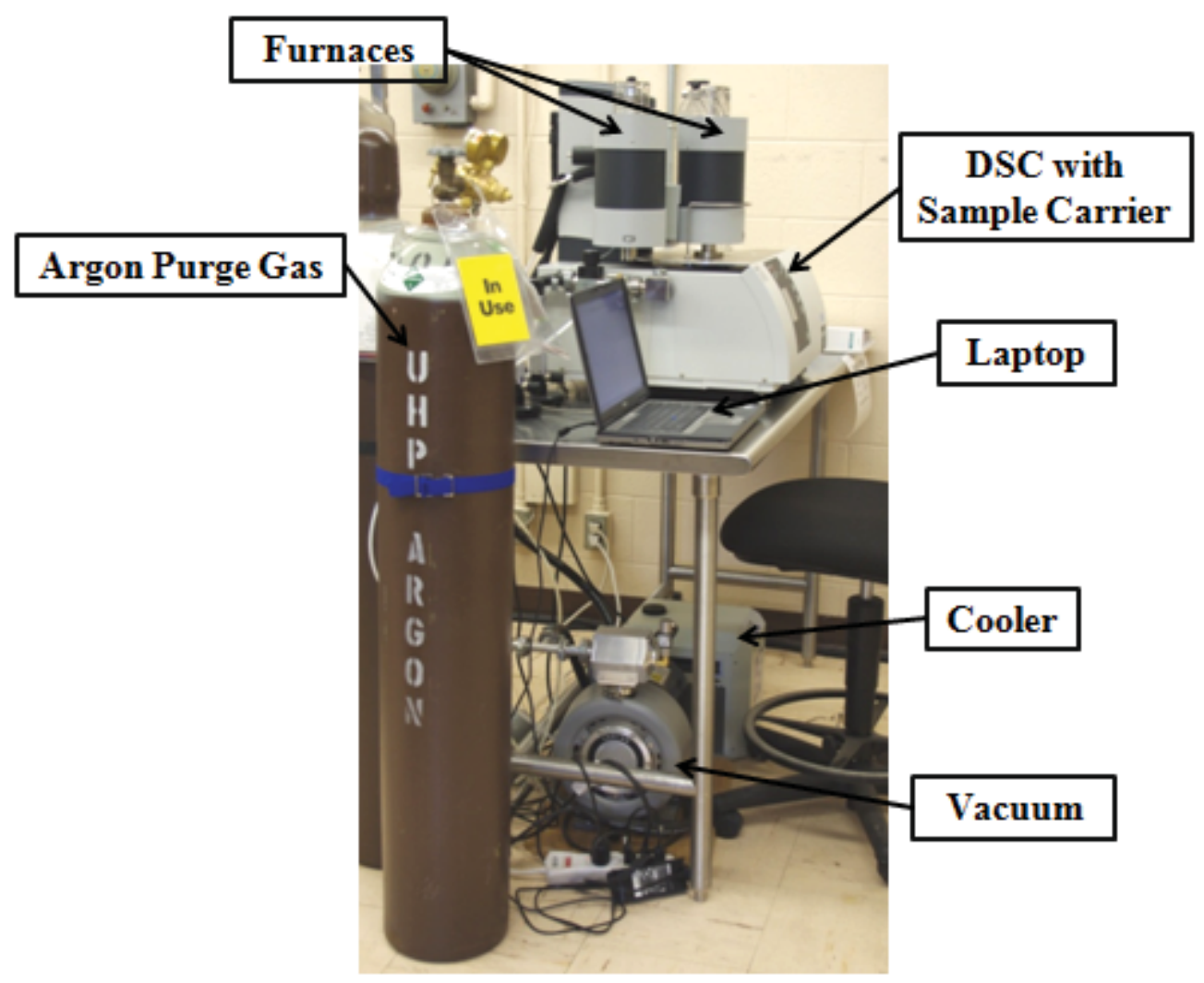

Figure 8. DSC setup in WCL.

All simulated salt samples were prepared in the glovebox to avoid exposing the hygroscopic salts to moisture and oxygen. To keep the DSC sample (10 mg, hygroscopic, homogenous, metal chloride salt) moisture and oxygen free, a unique crucible was used for DSC analysis. Even small amounts of moisture could affect the chemicals and would not yield accurate DSC results from the salt being simulated. A high-pressure DSC crucible made of chrome nickel steel with a gold plated surface was used and is seen in Figure 9.

The crucible consists of three parts: (1) lid, (2) seal, and (3) pan. The seal is placed on top of the pan, which contains approximately $10 \mathrm{mg}$ of sample, and the lid is screwed on locking the gold seal between the pan and lid. A torque screwdriver set to of $2.5 \mathrm{~N} \cdot \mathrm{m}$ is used to create the cold weld between the gold disk and the sample pan. The nominal diameter of the crucible is $6 \mathrm{~mm}$ with a $27 \mu \mathrm{l}$ capacity. The gold plated steel crucible can withstand a max internal pressure of 100 bar and has a maximum temperature rating of $500^{\circ} \mathrm{C}$. The maximum temperature rating is used more as a guideline; the crucibles have been subjected to temperatures up to $800^{\circ} \mathrm{C}$ and performed as expected.

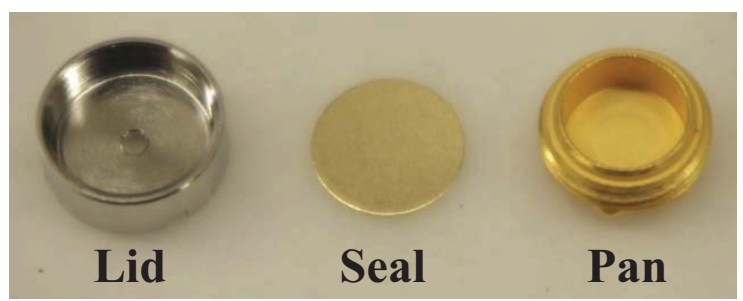

Figure 9. DSC crucible, gold plated chrome nickel steel crucible lid, seal, and pan. 
The hygroscopic sample was sealed in the DSC crucible then placed in a labeled plastic bag and transferred out of the glovebox along with a reference (empty) crucible. The reference and sample crucibles were placed on the sample carrier of the DSC and a file was setup specific for that sample. The sample file consists of information about the reference, sample crucible weights, sample weight, argon purge, protective gas flow rates, calibrations, heating rates, and temperature ranges. For this study a platinum $(\mathrm{Pt})$ furnace was used with a temperature range, room temperature $(\mathrm{RT})$ to $1500^{\circ} \mathrm{C}$, temperatures higher than $750^{\circ} \mathrm{C}$ were not needed. The DSC also equipped with a silver furnace (RT to $650^{\circ} \mathrm{C}$ ) was not used because the temperature range was not broad enough for this study.

Ultra high purity argon gas was purged through the furnace during experiments but was not actually needed; sealed crucibles were used to protect the samples from contact with moisture and oxygen. A TG-DSC $\left(\mathrm{C}_{\mathrm{p}}\right)$ sample carrier having a workable temperature range of RT to $1650^{\circ} \mathrm{C}$ was used in the DSC. Two DSC crucibles were placed on the sample carrier: (1) empty reference crucible and (2) sample crucible plus sample and both crucibles were made of the same materials and had similar weights. Data is acquired and saved on the instrument laptop (Figure 8) and then copied to a thumb drive. A detailed description of the DSC and sample carrier functions will not be discussed here, but a detailed discussion on DSC functions and operations is contained in Ref. 2.

Parameters that were held constant through all experimentation were: argon protective and purge gas flow rates, cooler temperature, sealing torque, sample size, crucible material, heating/cooling rate, sample carrier, Pt DSC furnace, calibration file, and laboratory temperature. Some parameters such as laboratory temperature fluctuated, but did not deviate too much from an average lab temperature of $25^{\circ} \mathrm{C}$. All samples were subject to different temperature ranges depending on the transition and melting temperature range. Because some samples, such as eutectic LiCl-KCl, melt at low temperatures, and other samples, like pure $\mathrm{LiCl}$, melt over $600^{\circ} \mathrm{C}$, the samples would be subject to different temperature profiles (initial and final temperature) in the DSC so the melting peak of each sample could be seen within the set temperature range.

\subsection{Calibration}

Calibration means establishing the set of operations using a set of conditions to get as accurate data as possible from the instrument when compared to a set of standards (Ref. 3). A calibration must be run using no less than three standards and multiple scan rates. A calibration must encompass the temperature range in which the sample will be analyzed. Before any DSC experimentation was performed, a calibration curve was made using chemical standards and a predetermined set of conditions that would not vary was established to ensure the instrument was providing accurate results. Five calibration standards were used for this study as opposed to three to get the most accurate calibration file possible.

Temperature calibration means the unambiguous assignment of the temperature "indicated" by the instrument to the "true" temperature. Temperature and sensitivity calibrations were run on the sealed, nickel chrome steel, gold plated DSC crucibles using five standards provided by Netzsch:

1. Benzoic Acid $\left(\mathrm{C}_{6} \mathrm{H}_{5} \mathrm{COOH}\right)$

2. Rubidium Nitrate $\left(\mathrm{RbNO}_{3}\right)$

3. Potassium Perchlorate $\left(\mathrm{KClO}_{4}\right)$

4. Cesium Chloride $(\mathrm{CsCl})$

5. Potassium Chromate $\left(\mathrm{K}_{2} \mathrm{CrO}_{4}\right)$

Using the five standards, the temperature and sensitivity calibrations were performed from $120^{\circ} \mathrm{C}$ to $668^{\circ} \mathrm{C}$ for heating rates of $10 \mathrm{~K} / \mathrm{min}$ and $2 \mathrm{~K} / \mathrm{min}$. Figure 10 and Figure 11 show the temperature calibration curves for $10 \mathrm{~K} / \mathrm{min}$ and $2 \mathrm{~K} / \mathrm{min}$ heating rates respectively. The DSC curves for each standard used to construct Figures 10 and 11 are located in Appendix B. All five standards used produced melting temperatures within $2^{\circ} \mathrm{C}$ for the $10 \mathrm{~K} / \mathrm{min}$ heating rate and within $5^{\circ} \mathrm{C}$ of the reported literature value with a heating rate of $2 \mathrm{~K} / \mathrm{min}$. 


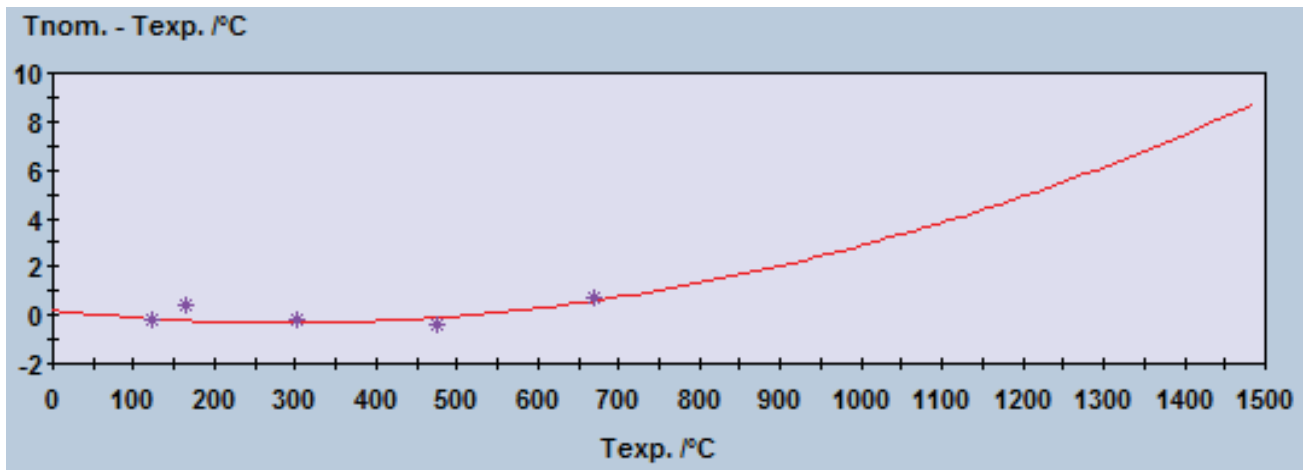

Figure $10.10 \mathrm{~K} / \mathrm{min}$ temperature calibration curve for Pt furnace using chrome nickel steel DSC crucible.

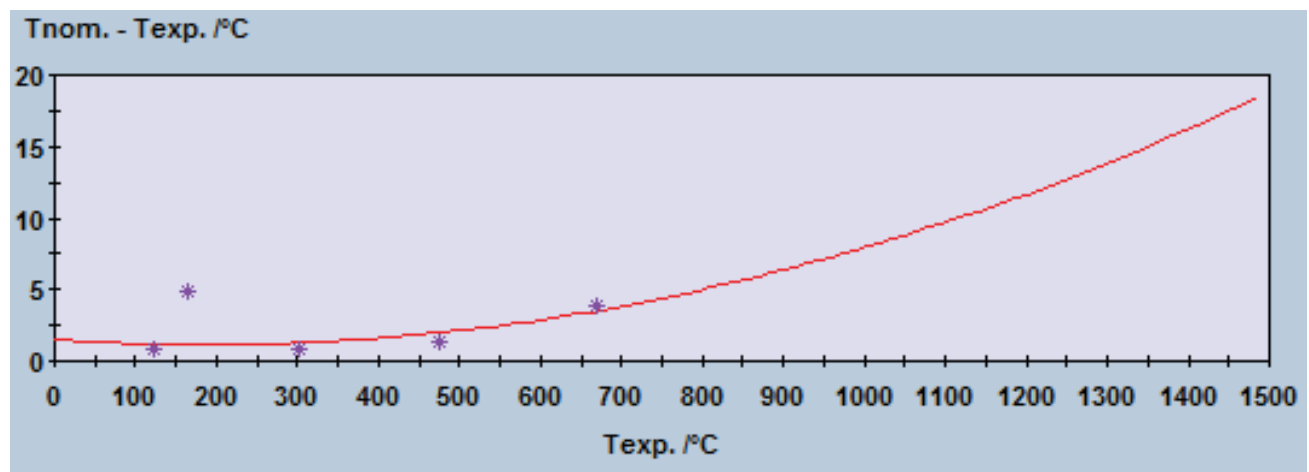

Figure $11.2 \mathrm{~K} / \mathrm{min}$ temperature calibration curve for Pt furnace using chrome nickel steel DSC crucible.

A sensitivity calibration, also called a heat flow rate calibration, is made from the same data used to make the temperature calibration. Heat is the measured peak area, which is the area from the start of a peak to the end of a peak, taken from the DSC curve. The area under the curve is the amount of heat needed for a transition to occur. By comparing the measured value to a standard value (literature value), a better understanding of the heat flow of the machine is known (Ref. 2). Figure 12 and Figure 13 show the sensitivity calibration curves for $10 \mathrm{~K} / \mathrm{min}$ and $2 \mathrm{~K} / \mathrm{min}$ heating rates respectively. The DSC curves used to construct Figures 12 and 13 are located in Appendix B. The sensitivity calibration curves indicate that as the temperature increases, the sensitivity of the instrument decreases. The sensitivity calibration curve was loaded into the software as each sample was run in the DSC to correct for the decreased sensitivity at higher temperatures.

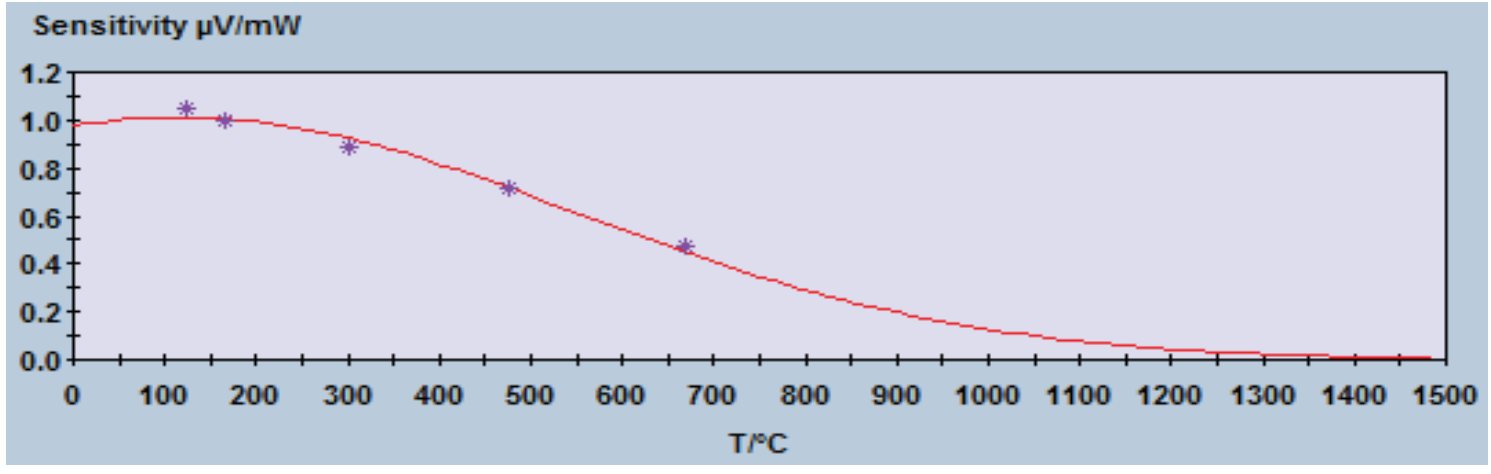

Figure $12.10 \mathrm{~K} / \mathrm{min}$ sensitivity calibration curve for Pt furnace using chrome nickel steel DSC crucible. 


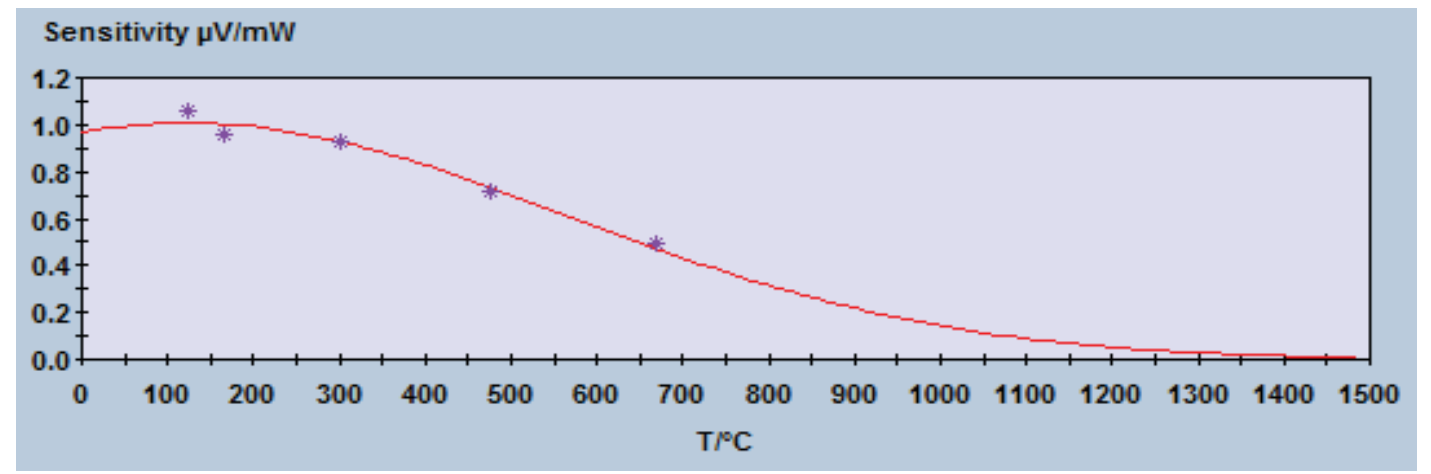

Figure $13.2 \mathrm{~K} / \mathrm{min}$ sensitivity calibration curve for Pt furnace using chrome nickel steel DSC crucible.

\subsection{LiCl-KCl Study}

By studying the LiCl-KCl system, a better understanding of DSC curves with various heating and cooling rates and operating parameters was obtained. Eight $\mathrm{LiCl}-\mathrm{KCl}$ salts, each with different $\mathrm{LiCl}$ concentrations, were prepared using high purity, anhydrous, $\mathrm{LiCl}$ and $\mathrm{KCl}$. Table 3 shows the amount and compositions of $\mathrm{LiCl}$ and $\mathrm{KCl}$ used for each of the eight samples. The composition was given in $\mathrm{wt} \%$ and in mole percent $(\mathrm{mol} \%)$. The eight $\mathrm{LiCl}-\mathrm{KCl}$ samples were prepared similar to the simulated salt samples described in previous sections. Sample prep involves: (1) calculations, (2) measuring and melting, (3) homogenization, and (4) DSC analysis. The only significant difference is sample size. For the LiCl-KCl study the sample size was $\sim 2 \mathrm{~g}$. Equations $4-9$ show the equations used for calculating mol $\mathrm{LiCl}, \mathrm{mol} \mathrm{KCl}$, mol fraction $\mathrm{LiCl}$, mol fraction $\mathrm{KCl}$, wt $\% \mathrm{LiCl}$, and $\mathrm{wt} \% \mathrm{KCl}$ of sample 2 in Table 3 (shaded gray). Similar calculations were used to calculate values for other samples in Table 3.

Table 3. Various compositions used in LiCl- $\mathrm{KCl}$ study.

\begin{tabular}{|c|c|c|c|c|c|c|c|c|c|}
\hline Sample & $\begin{array}{c}\text { LiCl Added, } \\
\mathrm{g}\end{array}$ & $\begin{array}{c}\mathrm{KCl} \text { Added, } \\
\mathrm{g}\end{array}$ & $\begin{array}{c}\text { Total } \\
\mathrm{LiCl}-\mathrm{KCl}, \\
\mathrm{g}\end{array}$ & $\begin{array}{c}\mathrm{LiCl}, \\
\mathrm{mol}\end{array}$ & $\begin{array}{c}\mathrm{KCl}, \\
\mathrm{mol}\end{array}$ & $\begin{array}{c}\mathrm{LiCl}, \\
\mathrm{mol} \%\end{array}$ & $\begin{array}{c}\mathrm{KCl}, \\
\mathrm{mol} \%\end{array}$ & $\begin{array}{c}\mathrm{LiCl}, \\
\mathrm{wt} \%\end{array}$ & $\begin{array}{c}\mathrm{KCl}, \\
\mathrm{wt} \%\end{array}$ \\
\hline 1 & 0.0000 & 0.7500 & 0.7500 & 0.0000 & 0.0101 & 0 & 100.00 & 0 & 100.00 \\
\hline 2 & 0.3292 & 0.7502 & 1.0794 & 0.0078 & 0.0101 & 43.56 & 56.44 & 19.97 & 80.03 \\
\hline 3 & -- & -- & -- & -- & -- & 59.20 & 40.80 & 44.00 & 56.00 \\
\hline 4 & 0.8796 & 0.7502 & 1.6298 & 0.0207 & 0.0101 & 67.34 & 32.66 & 40.00 & 60.00 \\
\hline 5 & 1.4073 & 0.1999 & 1.6072 & 0.0332 & 0.0027 & 92.53 & 7.47 & 80.01 & 19.99 \\
\hline 6 & 1.0000 & 0.0000 & 1.0000 & 0.0236 & 0.0000 & 100 & 0 & 100.00 & 0 \\
\hline 7 & 1.2714 & 0.5589 & 1.8303 & 0.0300 & 0.0075 & 79.99 & 20.01 & 56.40 & 43.60 \\
\hline 8 & 0.4242 & 2.9826 & 3.4068 & 0.0100 & 0.0400 & 20.00 & 80.00 & 7.48 & 92.52 \\
\hline
\end{tabular}

$$
\boldsymbol{m o l} \mathbf{L i C l}=0.3292 \mathrm{gLiCl} \times \frac{1 \mathrm{~mol} \mathrm{LiCl}}{42.394 \mathrm{gLiCl}}=0.0078 \mathrm{~mol} \mathrm{LiCl} \quad(e q 4)
$$

$$
\operatorname{mol} \mathbf{K C l}=0.7502 \mathrm{~g} \mathrm{KCl} \times \frac{1 \mathrm{~mol} \mathrm{KCl}}{74.5513 \mathrm{~g} \mathrm{KCl}}=0.0101 \mathrm{~mol} \mathrm{KCl} \quad(e q 5)
$$

$$
\text { mol fraction } \mathbf{L i C l}=\frac{0.0078 \mathrm{~mol} \mathrm{LiCl}}{0.0078 \mathrm{~mol} \mathrm{LiCl}+0.0101 \mathrm{~mol} \mathrm{KCl}}=0.4356 \mathrm{LiCl} \quad(\text { eq 6) }
$$




$$
\text { mol fraction } \mathbf{K C l}=\frac{0.0101 \mathrm{~mol} \mathrm{KCl}}{0.0101 \mathrm{~mol} \mathrm{KCl}+0.0078 \mathrm{~mol} \mathrm{LiCl}}=0.5644 \mathrm{KCl} \quad(e q \mathrm{7})
$$

$\boldsymbol{w t} \% \mathbf{L i C l}=\frac{0.3292 \mathrm{~g} \mathrm{LiCl} \times\left(42.394 \frac{\mathrm{g} \mathrm{LiCl}}{\mathrm{mol} \mathrm{LiCl}}\right)}{0.3292 \mathrm{~g} \mathrm{LiCl} \times\left(42.394 \frac{\mathrm{g} \mathrm{LiCl}}{\mathrm{mol} \mathrm{LiCl}}\right)+0.7502 \mathrm{~g} \mathrm{KCl} \times\left(74.5513 \frac{\mathrm{g} \mathrm{KCl}}{\mathrm{mol} \mathrm{KCl}}\right)} \times 100=19.97 \mathrm{wt} \% \mathrm{LiCl} \quad$ (eq 8)

$\boldsymbol{w} \boldsymbol{t} \% \boldsymbol{K C l}=\frac{0.7502 \mathrm{~g} \mathrm{KCl} \times\left(74.5513 \frac{\mathrm{g} \mathrm{KCl}}{\mathrm{mol} \mathrm{KCl}}\right)}{0.7502 \mathrm{~g} \mathrm{KCl} \times\left(74.5513 \frac{\mathrm{g} \mathrm{KCl}}{\mathrm{mol} \mathrm{KCl}}\right)+0.3292 \mathrm{~g} \mathrm{LiCl} \times\left(42.394 \frac{\mathrm{gLiCl}}{\mathrm{mol} \mathrm{LiCl}}\right)} \times 100=80.03 \mathrm{wt} \% \mathrm{KCl} \quad$ (eq 9)

\section{**All calculations are for Sample 2}

Table 4 gives the average values of the eutectic and liquidus temperatures of the eight samples with different compositions of LiCl. Values were obtained from the DSC curves in Appendix C. The values in this Table are an average value based on the three different heating curves for heating rates of $10 \mathrm{~K} / \mathrm{min}$ and $2 \mathrm{~K} / \mathrm{min}$. Single component salts (Sample 1 and Sample 6) do not have a eutectic and melting temperature; they have only a melting temperature. Two dashes (--) are used to denote when a temperature is not applicable to the sample. Notice in Table 4 that Sample 3 has the same eutectic and liquidus temperature; this is because Sample 3 is the eutectic composition of LiCl-KCl.

Table 4: Eutectic and Liquidus temperatures for LiCl-KCl study

\begin{tabular}{|c|c|c|c|c|c|}
\hline \multirow[b]{2}{*}{ Sample } & \multirow{2}{*}{$\begin{array}{l}\mathrm{LiCl}, \\
\text { wt } \%\end{array}$} & \multicolumn{2}{|c|}{$10 \mathrm{~K} / \mathrm{min}$ Heating Rate } & \multicolumn{2}{|c|}{$2 \mathrm{~K} / \mathrm{min}$ Heating Rate } \\
\hline & & $\begin{array}{c}\text { Eutectic Temp, } \\
{ }^{\circ} \mathrm{C}\end{array}$ & $\begin{array}{c}\text { Liquidus Temp, } \\
{ }^{\circ} \mathrm{C}\end{array}$ & $\begin{array}{c}\text { Eutectic Temp, } \\
{ }^{\circ} \mathrm{C}\end{array}$ & $\begin{array}{c}\text { Liquidus Temp, } \\
{ }^{\circ} \mathrm{C}\end{array}$ \\
\hline 1 & 0 & -- & 769.7 & -- & 772.6 \\
\hline 2 & 20 & 354.1 & 522.3 & 354.7 & -- \\
\hline 3 & 44 & 354.7 & 354.7 & 354.4 & 354.4 \\
\hline 4 & 40 & 353.0 & 426.2 & 354.7 & 428.1 \\
\hline 5 & 80 & 353.6 & 578.1 & 354.5 & 577.0 \\
\hline 6 & 100 & -- & 605.8 & -- & 607.8 \\
\hline 7 & 56.4 & 353.6 & 511.7 & 354.8 & 512.4 \\
\hline 8 & 7.50 & 352.0 & 682.4 & 353.7 & 687.8 \\
\hline
\end{tabular}

The LiCl-KCl phase diagram in Figure 14 was constructed using the values from Table 4 . The triangles $(\Delta)$ represent values obtained using a $10 \mathrm{~K} / \mathrm{min}$ heating rate and the squares $(\square)$ represent values obtained using a $2 \mathrm{~K} / \mathrm{min}$ heating rate. The value for Sample 2 at $2 \mathrm{~K} / \mathrm{min}$ was omitted because the liquidus peak of the DSC curve was not clearly visible due to a slow heating rate. 
Figure 15 shows a comparison between the $\mathrm{LiCl}-\mathrm{KCl}$ data from this work and data obtained from other LiCl-KCl studies (Zemczuzny (1910); Richards (1917); Schaefer (1920); Elchagardus (1932), as cited in Korin 1997). The blue circular points (๑) in Figure 15 are experimental results of this LiCl-KCl study. The data obtained in this research lies within $\pm 5^{\circ} \mathrm{C}$ of other reported liquidus and eutectic temperatures.

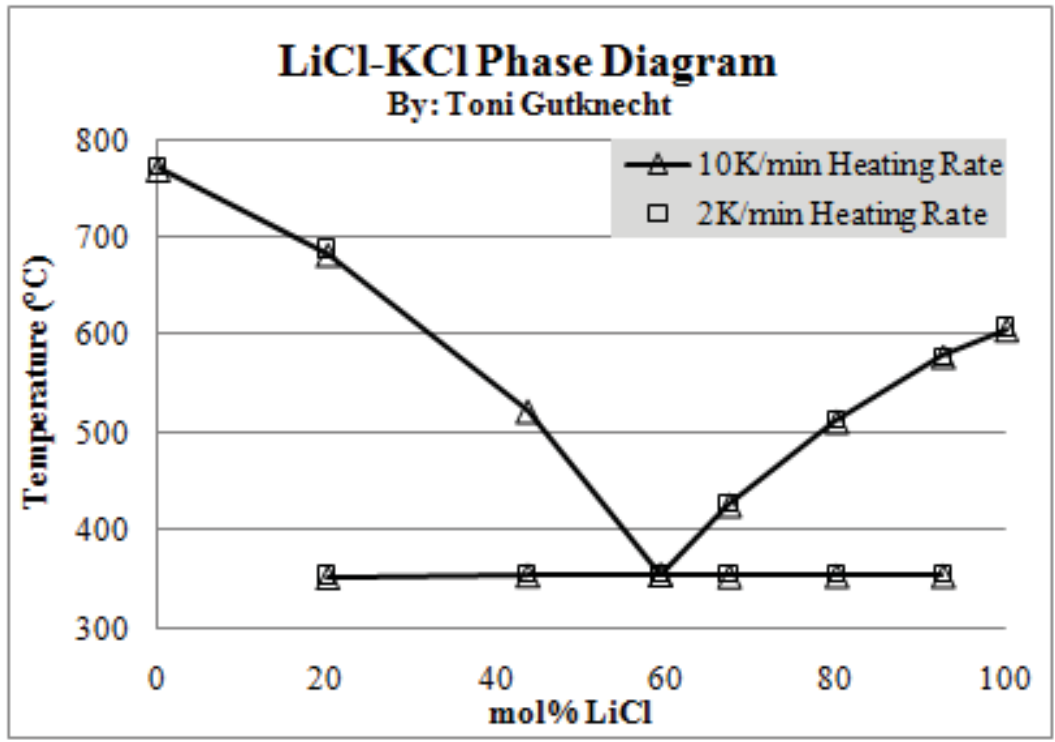

Figure 14. LiCl-KCl phase diagram based off DSC experimental results.

LiCl-KCl Phase Diagram

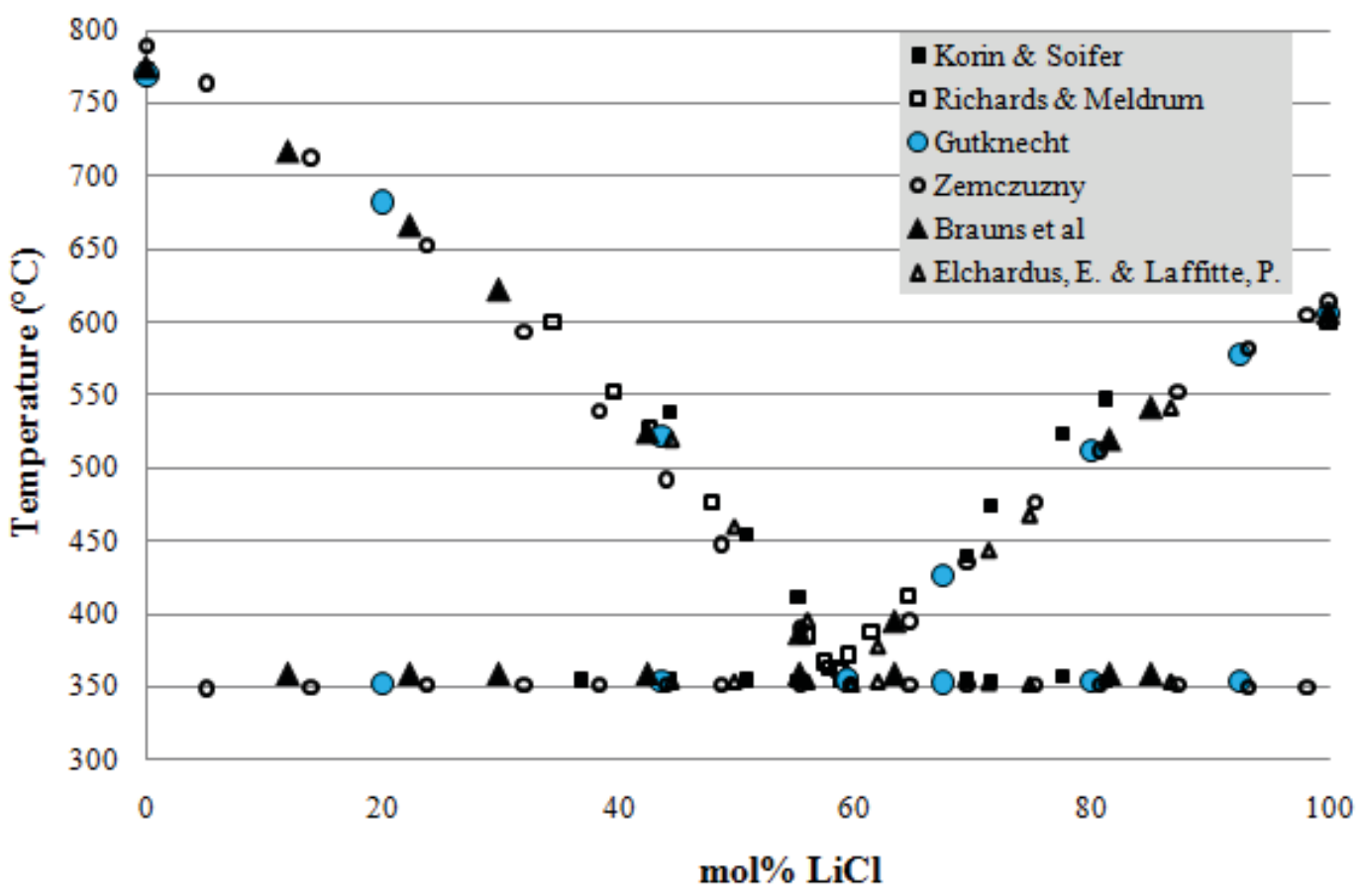

Figure 15. LiCl-KCl phase diagram comparing other studies with this study. 


\section{RESULTS BASED ON PROJECT}

The results are in the form of DSC curves. From the DSC curves, a liquidus temperature can be determined. Two heating rates were used for this study, and at each heating rate, four temperature cycles were run. The first cycle curve (used to condition the sample in the Netzsch instrument) was omitted and the final three curves were used. A thermogram which contained the DSC curve was useful in determining onset and peak temperatures. For this study the final peak temperature was deemed the liquidus temperature and is the temperature at which the entire sample is a homogenous melt. On each thermogram, three heating cycles are represented at $10 \mathrm{~K} / \mathrm{min}$. The first cycle is represented with a black DSC curve, the second is represented with a blue DSC curve, and the final cycle is represented by a red DSC curve. It may be difficult to distinguish between the red, blue, and black curves because they lay directly on top of one another in some thermograms. Two heating rates, $2 \mathrm{~K} / \mathrm{min}$ and $10 \mathrm{~K} / \mathrm{min}$, were run for each sample. In the results section, thermograms are only shown for the $10 \mathrm{~K} / \mathrm{min}$ heating rate; $2 \mathrm{~K} / \mathrm{min}$ thermograms can be found in Appendixes D and E.

On each thermogram the onset, peak, and liquidus temperature are listed. Heating and cooling curves are labeled and the sample name and heating rate is shown on the thermogram to avoid ambiguity and confusion. A short sample description for each sample listing its concentration and the amount of heavy metal fuel processed is discussed for each sample and its corresponding thermogram. A table is shown after each thermogram which lists the average onset and thermogram values for the corresponding thermogram. The values were determined by averaging the results from the three cycles in each thermogram. For future discussion, the term DSC curve is used interchangeably with thermogram.

Evaluation of the Mk-IV electrolyte was done after the processing of two different reactor fuels. The first is processing 27 batches of FFTF fuel each containing nearly $11.5 \mathrm{~kg}$ of heavy metal fuel. FFTF processing is represented by making two $15 \mathrm{~g}$ simulated salt samples: (1) before FFTF processing and (2) after completing FFTF processing. The composition of the two FFTF samples is listed in Table 5. INTEC or fissium fuel will be processed in 165 batches with each batch containing nearly $12 \mathrm{~kg}$ of heavy metal fuel. INTEC fuel was simulated using seven 15 -g simulated salt samples. The composition of the seven INTEC fuel samples is listed in Table 7. Appendix A shows the exact weight of all chloride salts used to make the $15 \mathrm{~g}$ sample.

\subsection{FFTF Fuel Processing}

It will take approximately 27 batches to process the FFTF fuel inventory in the Mk-IV ER. In each batch there is assumed to be 11,574 g of heavy metal fuel processed (Ref. 2). The wt $\%$ of LiCl-KCl in the Mk-IV ER before FFTF fuel was processed is $76.8 \mathrm{wt} \% \mathrm{LiCl}-\mathrm{KCl}$ with the other $23.2 \mathrm{wt} \%$ being impurity metal chlorides from fuel processing. After FFTF fuel has been processed the wt $\%$ of LiCl-KCl is $70.4 \mathrm{wt} \%$. As the $\mathrm{wt} \%$ of $\mathrm{LiCl}-\mathrm{KCl}$ decreases, the $\mathrm{wt} \%$ of impurities increases. Two $15 \mathrm{~g}$ simulated salt samples were made to represent the salt in the Mk-IV ER: (i) before and (ii) after FFTF fuel is processed. The composition of the Mk-IV salt and the composition of the simulated salt samples are made to be the same and are listed in Table 5. For the actual wt $\%$ of each fission product (FP) see Appendix A. The amount of $\mathrm{PuCl}_{3}$ present in the salt more than doubles and the $\mathrm{FP}$ chloride concentration increases by about $2.5 \mathrm{wt} \%$ between the before and after FFTF samples. 
Table 5. Composition of Mk-IV salt before and after FFTF fuel processing.

\begin{tabular}{|l|c|c|}
\cline { 2 - 3 } \multicolumn{1}{c|}{} & $\begin{array}{c}\text { Mk-IV salt composition } \\
\text { before FFTF, } \\
\mathrm{wt} \%\end{array}$ & $\begin{array}{c}\text { Mk-IV salt composition } \\
\text { after FFTF, } \\
\mathrm{wt} \%\end{array}$ \\
\hline $\mathrm{LiCl}-\mathrm{KCl}$ & 76.84 & 70.39 \\
\hline $\mathrm{UCl}_{3}$ & 7.60 & 8.41 \\
\hline $\mathrm{PuCl}_{3}$ & 1.42 & 3.68 \\
\hline $\mathrm{NaCl}$ & 8.30 & 9.37 \\
\hline $\mathrm{FP} \mathrm{Chlorides}$ & 5.84 & 8.15 \\
\hline
\end{tabular}

Figure 16 is a thermogram comparing the Mk-IV molten salt before and after FFTF fuel processing run in the DSC with a heating/cooling rate of $10 \mathrm{~K} / \mathrm{min}$. In Figure 16 the blue line represents the Mk-IV salt before FFTF fuel was processes and the black line represents the Mk-IV salt after FFTF fuel was processed. Appendix D contains DSC curves using other heating rate for each sample. Values from Table 6 were taken from Figure 16 and thermograms in Appendix D.

The cooling curve will not be used due to super cooling of the salt which results in inaccurate peak and onset temperatures. The cooling curve can provide an indication as to what is happening to the sample upon cooling with respect to phase separation. The number of peaks present when cooling helps to determine the number of peaks on the heating curve. Sometimes peaks can overlap on the heating curve and cannot be accurately identified. This can be seen in Figure 16, in the heating curves there are two peaks present, the onset for Peak 1 occurs near $343^{\circ} \mathrm{C}$ for both samples. Peak 2 occurs near $379^{\circ} \mathrm{C}$ for the sample labeled 'Before FFTF fuel' and at $392^{\circ} \mathrm{C}$ for the sample labeled 'After FFTF fuel.' When cooling, the salt goes through three transitions labeled Peak 1, 2, and 3 (see Figure 16). 


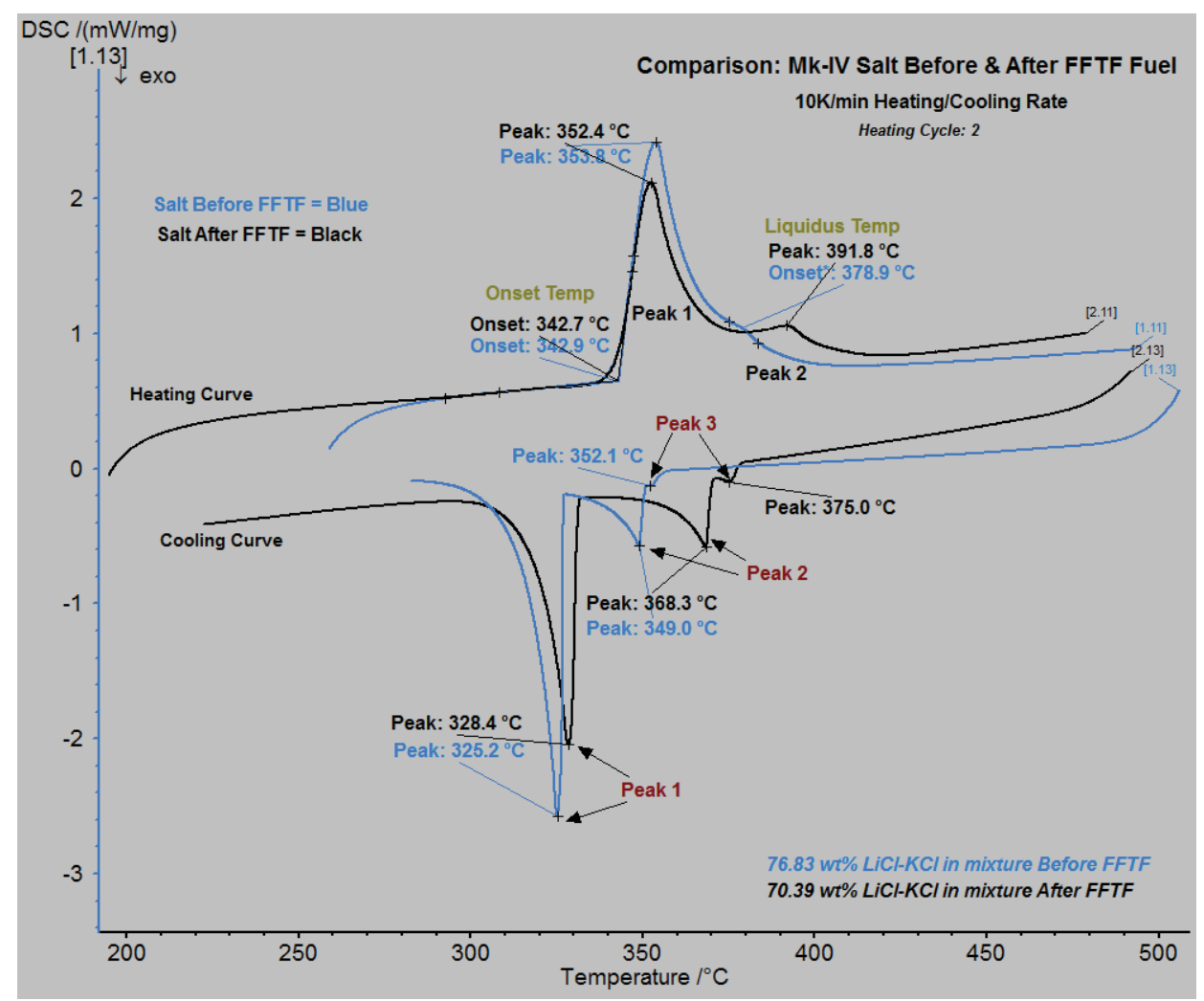

Figure 16. Comparison of Mk-IV salt before and after FFTF fuel.

Since Peak 3 is so small, it is not visible on the heating curve for $10 \mathrm{~K} / \mathrm{min}$. The heating and cooling peak and transition temperatures are compared in Table 6 . The presence of an extra peak during cooling may indicate a phase precipitating out of the salt at a higher temperature than bulk salt recrystallization occurs.

Due to a higher impurity concentration in the form of $\mathrm{Pu}, \mathrm{Na}$, and FPs in the after FFTF fuel sample, a higher liquidus temperature is confirmed from the DSC curves in Figure 16. The curve for after FFTF fuel indicates a liquidus of $392^{\circ} \mathrm{C}$ while the DSC curve for the salt before FFTF fuel processing has a liquidus temperature of $379^{\circ} \mathrm{C}$. Processing more than $312 \mathrm{~kg}$ of heavy metal FFTF fuel (Ref. 1) in the Mk-IV ER causes the liquidus temperature to increase by about $13^{\circ} \mathrm{C}$.

Table 6. Onset and liquidus temperature before and after FFTF fuel processing.

\begin{tabular}{|l|l|c|c|r|}
\cline { 2 - 4 } \multicolumn{2}{c|}{} & Before FFTF & After FFTF & $|\Delta \mathrm{T}|$ \\
\hline \multirow{4}{*}{ Heating Curve } & Onset Temp, ${ }^{\circ} \mathrm{C}$ & 342.9 & 342.7 & 0.2 \\
\cline { 2 - 5 } & Liquidus, ${ }^{\circ} \mathrm{C}$ & 378.9 & 391.8 & 12.9 \\
\hline \multirow{3}{*}{ Cooling Curve } & Peak $1,{ }^{\circ} \mathrm{C}$ & 325.2 & 328.4 & 3.2 \\
\cline { 2 - 5 } & Peak $2,{ }^{\circ} \mathrm{C}$ & 349.0 & 368.3 & 19.3 \\
\cline { 2 - 5 } & Peak $3,{ }^{\circ} \mathrm{C}$ & 352.1 & 375.0 & 22.9 \\
\hline
\end{tabular}

\subsection{INTEC Fuel}

There are approximately 165 batches of INTEC fuel that need to be processed. Each batch will process nearly $12 \mathrm{~kg}$ of heavy metal fuel. Seven simulated salt sample will be made representing compositions of the Mk-IV ER salt at various points during processing. Table 7 shows the name and composition of each sample that will represent the Mk-IV electrolyte. In Table 7 the samples are labeled in reference to the 
batch of INTEC fuel processed prior to the salt composition. INTEC B25 for instance represents the composition of the Mk-IV ER salt after the $25^{\text {th }}$ batch of INTEC has been processed.

Table 7. Simulated salt for Intec fuel samples.

\begin{tabular}{|l|c|c|c|c|}
\hline \multicolumn{1}{|c|}{ Sample } & $\begin{array}{c}\text { LiCl-KCl, } \\
\text { wt } \%\end{array}$ & $\begin{array}{c}\text { Actinide } \\
\text { Chlorides, } \\
\text { wt } \%\end{array}$ & $\begin{array}{c}\text { FP } \\
\text { Chlorides, } \\
\text { wt } \%\end{array}$ & $\begin{array}{c}\text { NaCl, } \\
\text { wt } \%\end{array}$ \\
\hline INTEC B25 & 66.2 & 12.5 & 10.1 & 11.2 \\
\hline INTEC B50 & 59.4 & 13.6 & 12.7 & 14.4 \\
\hline INTEC B75 & 54.8 & 12.3 & 15.3 & 17.6 \\
\hline INTEC B100 & 53.7 & 12.2 & 15.8 & 18.3 \\
\hline INTEC B125 & 48.3 & 13.3 & 17.8 & 20.7 \\
\hline INTEC B150 & 44.5 & 12.1 & 20.0 & 23.4 \\
\hline INTEC B165 & 44.9 & 13.1 & 19.4 & 22.6 \\
\hline
\end{tabular}

\subsubsection{INTEC B25}

INTEC B25 is the first of seven INTEC samples to be simulated in this study. Nearly $300 \mathrm{~kg}$ of heavy metal fuel was processed from the start of INTEC fuel processing to Batch 25 with $\sim 12 \mathrm{~kg}$ of heavy metal fuel being processed per batch (Ref. 1,2). The composition of salt in the Mk-IV ER after the $25^{\text {th }}$ batch of INTEC fuel was processed and the composition of the $15 \mathrm{~g}$ simulated salt samples (INTEC B25) is the following: (1) $66.2 \mathrm{wt} \% \mathrm{LiCl}-\mathrm{KCl}$, (2) $9.7 \mathrm{wt} \% \mathrm{UCl}_{3}$, (3) $3.3 \mathrm{wt} \% \mathrm{PuCl}_{3}$, (4) $11.2 \mathrm{wt} \% \mathrm{NaCl}$, and (5) $10.1 \mathrm{wt} \%$ FP Chlorides. Figure 17 shows the DSC results from INTEC B25 with a $10 \mathrm{~K} / \mathrm{min}$ heating rate. From Figure 17, INTEC B25 has an onset temperature of $340.2 \pm 0.5^{\circ} \mathrm{C}$ and a liquidus temperature of $397.2 \pm 3.0^{\circ} \mathrm{C}$. The onset and liquidus temperatures vary slightly with different heating rates; Appendix E shows thermograms of multiple heating rates for INTEC B25. Table 8 shows how the average onset and average liquidus temperature vary due to heating rate. 


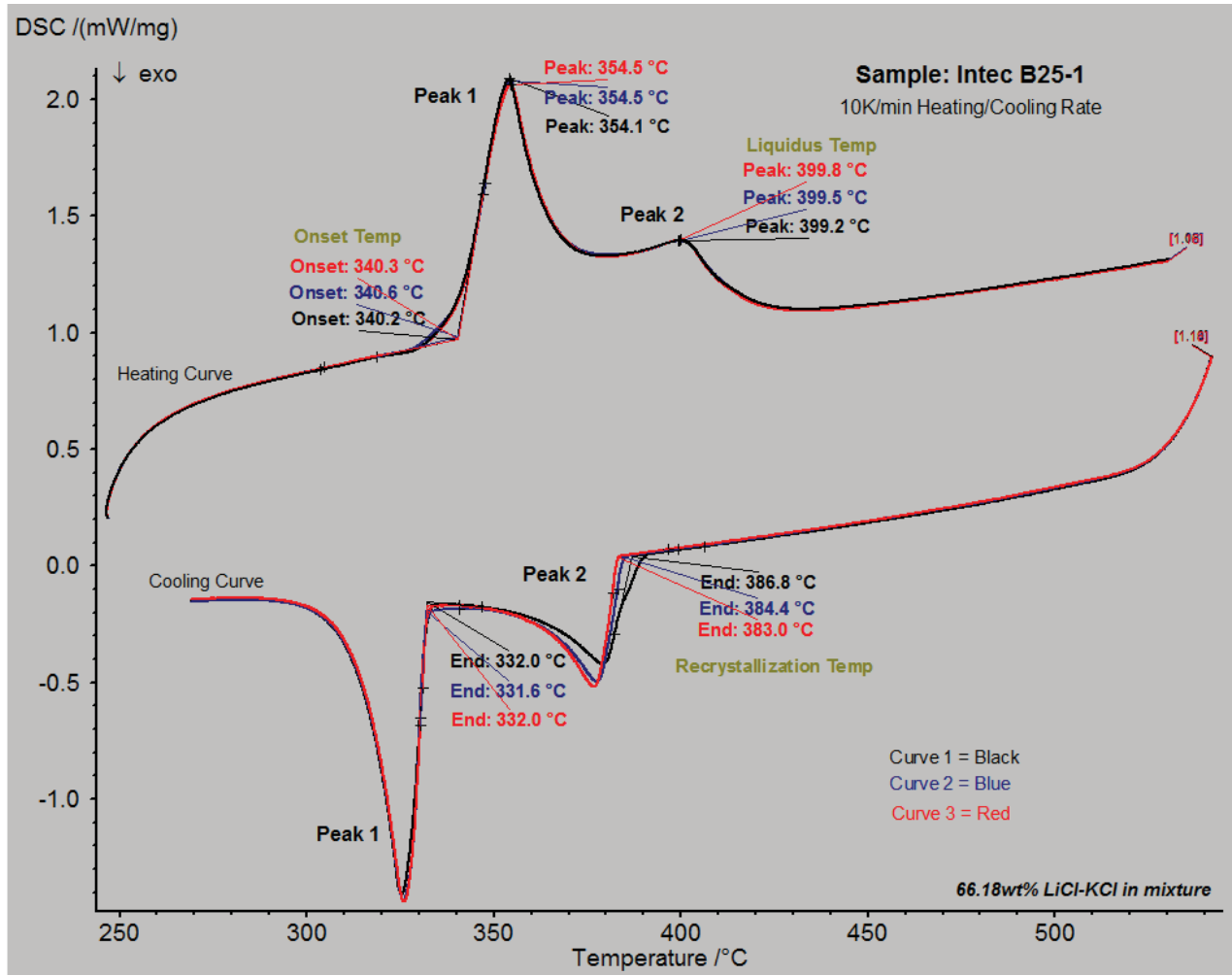

Figure 17. $10 \mathrm{~K} / \mathrm{min}$ DSC curves of INTEC B25.

Table 8. Onset and liquidus temperatures at multiple heating rates for INTEC B25.

\begin{tabular}{|l|c|c|}
\cline { 2 - 3 } \multicolumn{1}{c|}{} & $\begin{array}{c}\text { Onset Temp, } \\
{ }^{\circ} \mathrm{C}\end{array}$ & $\begin{array}{c}\text { Liquidus Temp, } \\
{ }^{\circ} \mathrm{C}\end{array}$ \\
\hline $10 \mathrm{~K} / \mathrm{min}$ & 340.4 & 399.5 \\
\hline $2 \mathrm{~K} / \mathrm{min}$ & 340.1 & 394.8 \\
\hline Average & $340.2 \pm 0.5$ & $397.2 \pm 3.0$ \\
\hline
\end{tabular}


A check for homogeneity and reproducibility was done with INTEC B25. To check for homogeneity a $10 \mathrm{mg}$ sample was taken from the B25 salt vial and placed in a DSC crucible labeled B25-1. The vial was stirred and shaken to "mix-up" the sample; another $10 \mathrm{mg}$ sample was taken from the vial and placed in a DSC crucible labeled B25-2. Each sample was subject to the same temperature profile in the DSC and the results are shown in Figure 18. The black curve represents B25-1 and the blue curve represents B25-2. If both $10 \mathrm{mg}$ samples taken from the INTEC B25 vial have the same composition, then the DSC curves should be nearly similar. In Figure 18 both curves nearly overlap each with the maximum difference in peak temperature occurring on the heating curve at Peak 1. The temperature difference between the onset, peak, and liquidus temperature is no greater than $1.7^{\circ} \mathrm{C}$, indicating that there is little to no difference between the two INTEC B25 samples, this concludes that the sample prep techniques yield a homogenous mixture. Table 9 compares the onset and peak temperatures for the heating and cooling curves in Figure 18.

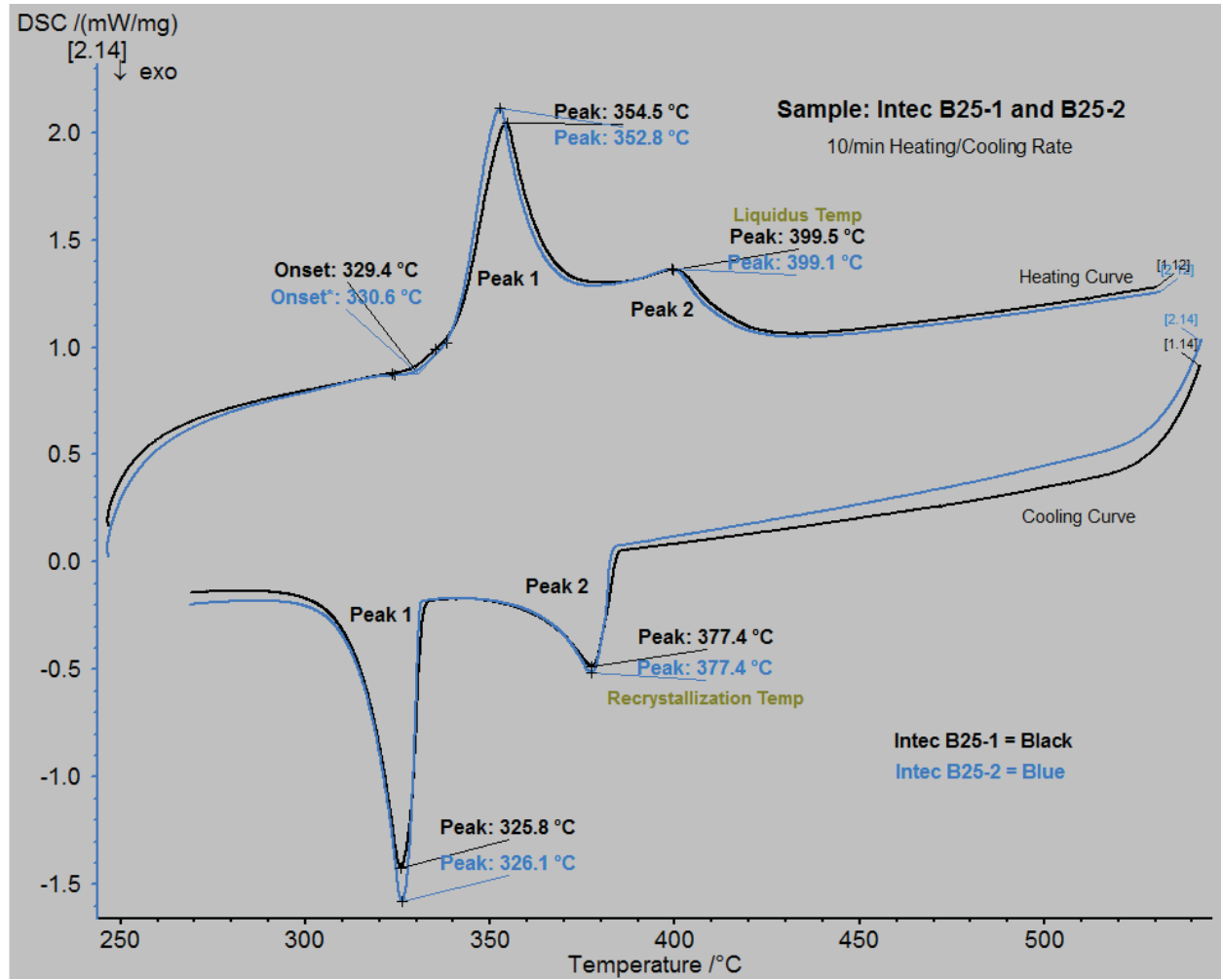

Figure 18. Comparison of thermograms for B25-1 and B25-2 (cycle 2) at $10 \mathrm{~K} / \mathrm{min}$.

Table 9. Onset and liquidus temperatures of INTEC B25-1 and B25-2.

\begin{tabular}{|l|l|c|c|c|}
\cline { 2 - 4 } \multicolumn{2}{c|}{} & B25-1 & B25-2 & $|\Delta \mathrm{T}|$ \\
\hline \multirow{4}{*}{ Heating Curve } & Onset Temp, ${ }^{\circ} \mathrm{C}$ & 329.4 & 330.6 & 1.2 \\
\cline { 2 - 5 } & Peak $1,{ }^{\circ} \mathrm{C}$ & 354.5 & 352.8 & 1.7 \\
\cline { 2 - 5 } & Liquidus, ${ }^{\circ} \mathrm{C}$ & 399.5 & 399.1 & 0.4 \\
\hline \multirow{3}{*}{ Cooling Curve } & Peak $1,{ }^{\circ} \mathrm{C}$ & 325.8 & 326.1 & 0.3 \\
\cline { 2 - 5 } & Peak $2,{ }^{\circ} \mathrm{C}$ & 377.4 & 377.4 & 0.0 \\
\hline
\end{tabular}


Running two samples of INTEC B25 is also a good instrument check to confirm the data is reproducible. Both the heating and cooling DSC curves in Figure 19 lie nearly on top of each other, indicating that the instrument is stable and can reproduce accurate results if needed. Checking for homogeneity and reproducibility ensures sample preparation techniques are sufficient and analysis equipment yields reliable, accurate results

\subsubsection{INTEC B50}

INTEC B50 is the second of seven INTEC samples to be simulated in this study. Nearly $600 \mathrm{~kg}$ of heavy metal fuel was processed from the start of INTEC fuel processing to Batch 50 with $\sim 12 \mathrm{~kg}$ of heavy metal fuel processed per batch (Ref. 1,2). The composition of salt in the Mk-IV ER after the $50^{\text {th }}$ batch of INTEC fuel was process and the composition of the $15 \mathrm{~g}$ simulated salt samples (INTEC B50) is: (1) $59.4 \mathrm{wt} \% \mathrm{LiCl}-\mathrm{KCl}$, (2) $10.2 \mathrm{wt} \% \mathrm{UCl}_{3}$, (3) $3.4 \mathrm{wt} \% \mathrm{PuCl}_{3}$, (4) $14.4 \mathrm{wt} \% \mathrm{NaCl}$, and (5) $12.7 \mathrm{wt} \% \mathrm{FP}$ chlorides. Figure 19 shows the DSC results of INTEC B50 with a $10 \mathrm{~K} / \mathrm{min}$ heating/cooling rate. From Figure 19, INTEC B50 has an onset temperature of $337.4 \pm 0.6^{\circ} \mathrm{C}$ and a liquidus temperature of $421.3 \pm 0.5^{\circ} \mathrm{C}$. The onset and liquidus temperatures will vary slightly with different heating rates; Appendix E shows thermograms with multiple heating rates for INTEC B50. Table 10 shows the changing onset and liquidus temperature due to heating rate.

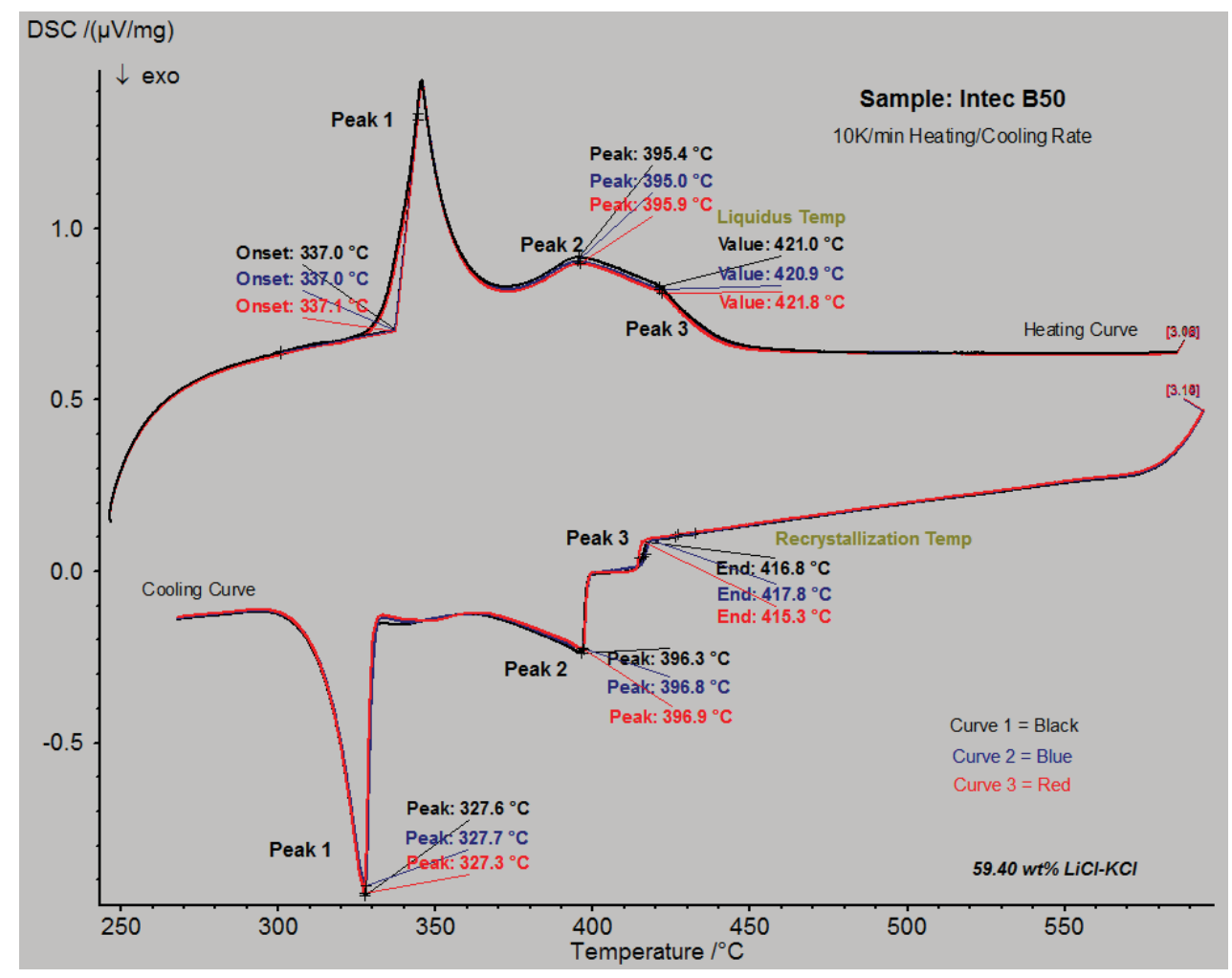

Figure 19. $10 \mathrm{~K} / \mathrm{min}$ DSC curves of INTEC B50. 
Table 10. Onset and liquidus temperatures at multiple heating rates for INTEC B50.

\begin{tabular}{|l|c|c|}
\cline { 2 - 3 } \multicolumn{1}{c|}{} & $\begin{array}{c}\text { Onset Temp, } \\
{ }^{\circ} \mathrm{C}\end{array}$ & $\begin{array}{c}\text { Liquidus Temp, } \\
{ }^{\circ} \mathrm{C}\end{array}$ \\
\hline $10 \mathrm{~K} / \mathrm{min}$ & 337.0 & 421.2 \\
\hline $2 \mathrm{~K} / \mathrm{min}$ & 337.8 & 421.2 \\
\hline Average & $337.4 \pm 0.6$ & $421.3 \pm 0.5$ \\
\hline
\end{tabular}

As the $\mathrm{wt} \%$ of impurities in the salt increases, $\mathrm{wt} \%$ of $\mathrm{LiCl}-\mathrm{KCl}$ decreases, the liquidus temperature should increase. By comparing the DSC curves of INTEC B25 and B50, it is clear that Peak 2, Figure 17, (INTEC B25) has been elongated in Figure 19 and a new peak, Peak 3, formed in Figure 19 (INTEC B50) due to increased impurity concentration. DSC curves cannot determine the composition or type of transformation that occurs at each peak; it can only verify in this case that an endothermic reaction is occurring. The liquidus temperature increased nearly $24^{\circ} \mathrm{C}$ from INTEC B25 to INTEC B50

\subsubsection{INTEC B75}

INTEC B75 is the third of seven INTEC samples to be simulated in this study. Nearly $900 \mathrm{~kg}$ of heavy metal fuel was processed from the start of INTEC fuel processing to Batch 75 with $\sim 12 \mathrm{~kg}$ of heavy metal fuel processed per batch (Ref. 1,2). The composition of salt in the Mk-IV ER after the $75^{\text {th }}$ batch of INTEC fuel was processed and the composition of the $15 \mathrm{~g}$ simulated salt samples (INTEC B75) is: (1) $54.8 \mathrm{wt} \% \mathrm{LiCl}-\mathrm{KCl}$, (2) $8.8 \mathrm{wt} \% \mathrm{UCl}_{3}$, (3) $3.6 \mathrm{wt} \% \mathrm{PuCl}_{3}$, (4) $17.6 \mathrm{wt} \% \mathrm{NaCl}$, and (5) $15.3 \mathrm{wt} \% \mathrm{FP}$ chlorides. Figure 20 shows the DSC results of INTEC B75 with a $10 \mathrm{~K} / \mathrm{min}$ heating/cooling rate. From Figure 20, INTEC B75 has an onset temperature of $329.2 \pm 2.5^{\circ} \mathrm{C}$ and a liquidus temperature of $460.6 \pm 0.9^{\circ} \mathrm{C}$. The onset and liquidus temperatures will vary slightly with different heating rates; Appendix E shows thermograms of multiple heating rates for INTEC B75. Table 11 shows the onset and liquidus temperature at $10 \mathrm{~K} / \mathrm{min}$ and $2 \mathrm{~K} / \mathrm{min}$ heating rates.

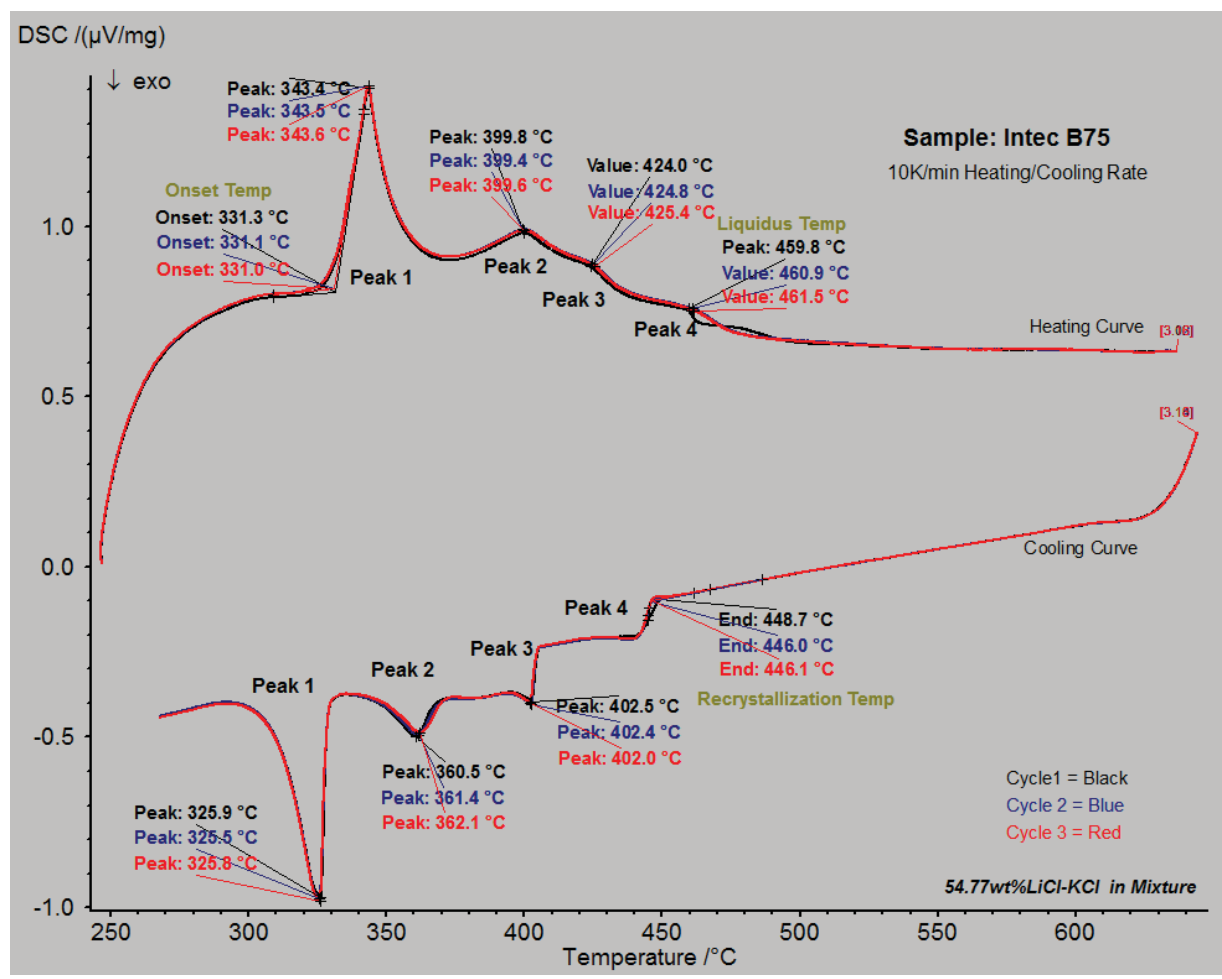

Figure $20.10 \mathrm{~K} / \mathrm{min}$ DSC curves of INTEC B75. 
Table 11. Onset and liquidus temperatures at multiple heating rates for INTEC B75.

\begin{tabular}{|l|c|c|}
\cline { 2 - 3 } \multicolumn{1}{c|}{} & $\begin{array}{c}\text { Onset Temp, } \\
{ }^{\circ} \mathrm{C}\end{array}$ & $\begin{array}{c}\text { Liquidus Temp, } \\
{ }^{\circ} \mathrm{C}\end{array}$ \\
\hline $10 \mathrm{~K} / \mathrm{min}$ & 331.1 & 460.7 \\
\hline $2 \mathrm{~K} / \mathrm{min}$ & 327.2 & 460.5 \\
\hline Average & $329.2 \pm 2.5$ & $460.6 \pm 0.9$ \\
\hline
\end{tabular}

As seen in the previous two samples, INTEC B25 and B50, the liquidus temperature of INTEC B75 has increased due to the increasing impurity concentration. Figure 20 shows that there are four peaks present on the DSC curve of B75. Again, the DSC curve only suggests that an energetic transition is occurring but does not help in determining what reaction is occurring. For B75 the bulk of the sample may be molten after Peak $2\left(\sim 400^{\circ} \mathrm{C}\right)$ however, there may still be a small portion of sample with a higher impurities concentration present that has not yet melted. Peaks 3 and 4 may represent the small portion of the high impurity sample as it melts. The sample is not a homogenous melt until the temperatures is above $460^{\circ} \mathrm{C}$.

\subsubsection{INTEC B100}

INTEC B100 is the fourth of seven INTEC samples to be simulated in this study. Nearly 1,200 kg of heavy metal fuel was processed from the start of INTEC fuel processing to Batch 100 with $\sim 12 \mathrm{~kg}$ of heavy metal fuel processed per batch (Ref. 1,2). The composition of salt in the Mk-IV ER after the $100^{\text {th }}$ batch of INTEC fuel was processed and the composition of the $15 \mathrm{~g}$ simulated salt samples (INTEC B100) is: (1) $53.7 \mathrm{wt} \% \mathrm{LiCl}-\mathrm{KCl}$, (2) $8.9 \mathrm{wt} \% \mathrm{UCl}_{3}$, (3) $3.3 \mathrm{wt} \% \mathrm{PuCl}_{3}$, (4) $18.3 \mathrm{wt} \% \mathrm{NaCl}$, and (5) $15.84 \mathrm{wt} \%$ FP chlorides. Figure 21 shows the DSC results of INTEC B100 with a $10 \mathrm{~K} / \mathrm{min}$ heating/cooling rate. From Figure 21, INTEC B100 has an onset temperature of $325.5 \pm^{\circ} 3.3^{\circ} \mathrm{C}$ and a liquidus temperature of $469.5 \pm 0.9^{\circ} \mathrm{C}$. The onset and liquidus temperatures will vary slightly with different heating rates; Appendix E shows thermograms of multiple heating rates for INTEC B100. Table 12 shows the onset and liquidus temperature at $10 \mathrm{~K} / \mathrm{min}$ and $2 \mathrm{~K} / \mathrm{min}$ heating rates. 


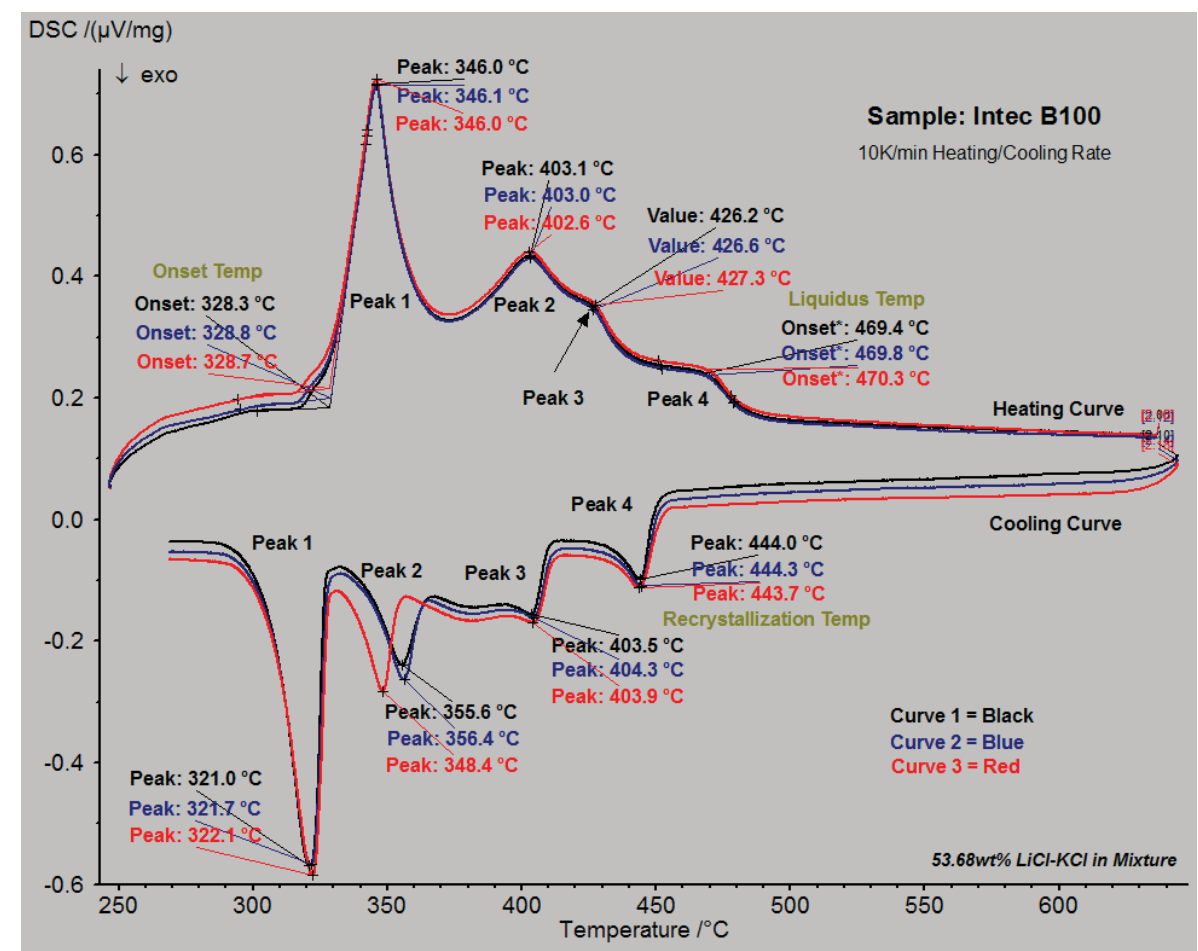

Figure $21.10 \mathrm{~K} / \mathrm{min}$ DSC curves of INTEC B100.

Table 12. Onset and liquidus temperatures at multiple heating rates for INTEC B100.

\begin{tabular}{|l|c|c|}
\cline { 2 - 3 } \multicolumn{1}{c|}{} & $\begin{array}{c}\text { Onset Temp, } \\
{ }^{\circ} \mathrm{C}\end{array}$ & $\begin{array}{c}\text { Liquidus Temp, } \\
{ }^{\circ} \mathrm{C}\end{array}$ \\
\hline $10 \mathrm{~K} / \mathrm{min}$ & 328.6 & 469.8 \\
\hline $2 \mathrm{~K} / \mathrm{min}$ & 322.3 & 469.2 \\
\hline Average & $325.5 \pm 3.3$ & $469.5 \pm 0.9$ \\
\hline
\end{tabular}

\subsubsection{INTEC B125}

INTEC B125 is the fifth of seven INTEC samples to be simulated in this study. Nearly $1,500 \mathrm{~kg}$ of heavy metal fuel was processed from the start of INTEC fuel processing to Batch 125 with $\sim 12 \mathrm{~kg}$ of heavy metal fuel processed per batch (Ref. 1, 2). The composition of salt in the Mk-IV ER after the $125^{\text {th }}$ batch of INTEC fuel was process and the composition of the $15 \mathrm{~g}$ simulated salt samples (INTEC B125) is: (1) $48.3 \mathrm{wt} \% \mathrm{LiCl}-\mathrm{KCl}$, (2) $9.9 \mathrm{wt} \% \mathrm{UCl}_{3}$, (3) $3.4 \mathrm{wt} \% \mathrm{PuCl}_{3}$, (4) $20.7 \mathrm{wt} \% \mathrm{NaCl}$, and (5) $17.8 \mathrm{wt} \% \mathrm{FP}$ chlorides. Figure 22 shows the DSC results of INTEC B125 with a $10 \mathrm{~K} / \mathrm{min}$ heating/cooling rate. From Figure 22, INTEC B125 has an onset temperature of $326.2 \pm 0.7^{\circ} \mathrm{C}$ and a liquidus temperature of $490.1 \pm 0.8^{\circ} \mathrm{C}$. The onset and liquidus temperatures will vary slightly with different heating rates; Appendix E shows thermograms of multiple heating rates for INTEC B125. Table 13 shows the onset and liquidus temperature at $10 \mathrm{~K} / \mathrm{min}$ and $2 \mathrm{~K} / \mathrm{min}$ heating rates. Table 13 shows the onset and liquidus temperature at $10 \mathrm{~K} / \mathrm{min}$ and $2 \mathrm{~K} / \mathrm{min}$ heating rates. 


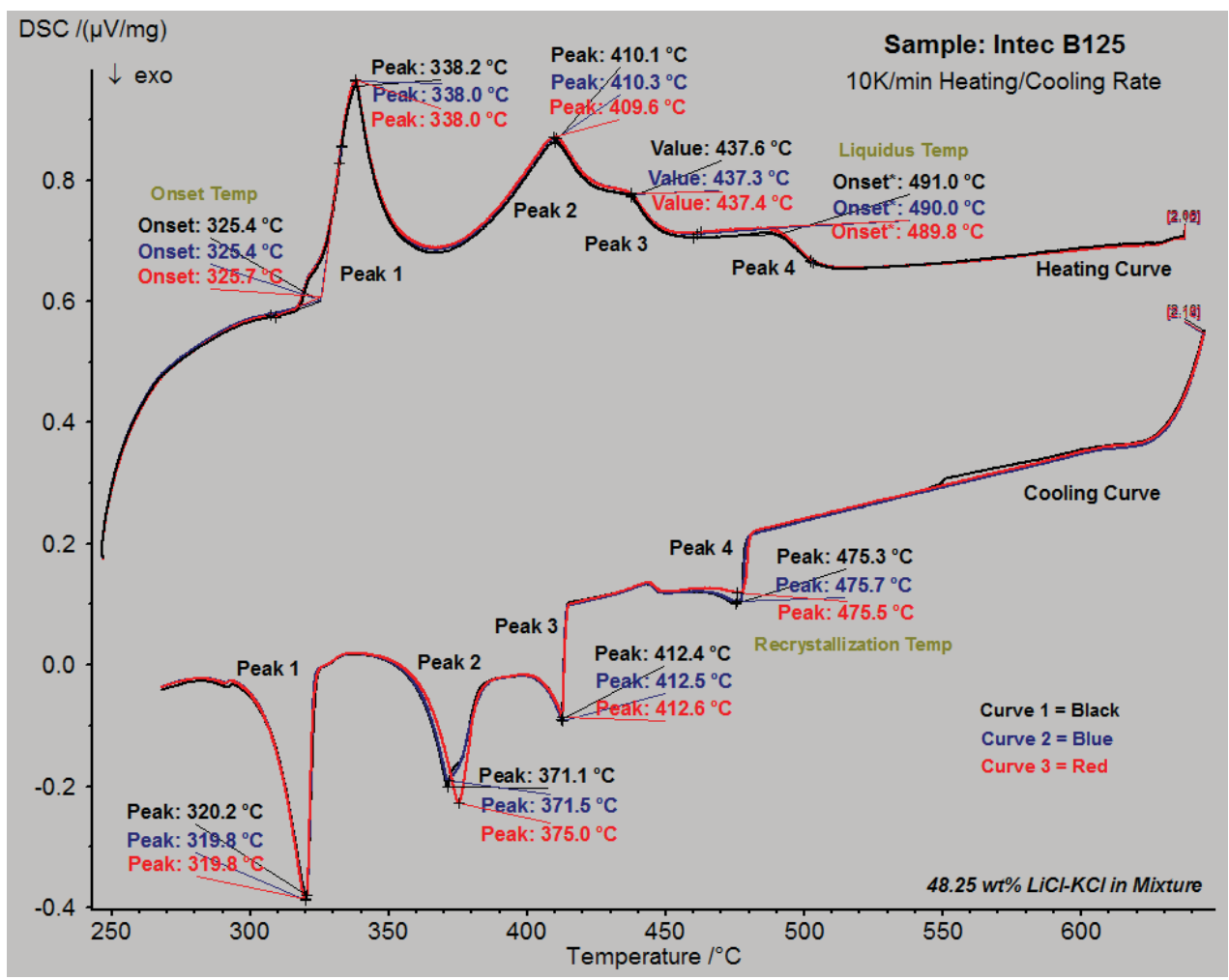

Figure 22. $10 \mathrm{~K} / \mathrm{min}$ DSC curves of INTEC B125.

Table 13. Onset and liquidus temperatures at multiple heating rates for INTEC B125.

\begin{tabular}{|l|c|c|}
\cline { 2 - 3 } \multicolumn{1}{c|}{} & $\begin{array}{c}\text { Onset Temp, } \\
{ }^{\circ} \mathrm{C}\end{array}$ & $\begin{array}{c}\text { Liquidus Temp, } \\
{ }^{\circ} \mathrm{C}\end{array}$ \\
\hline $10 \mathrm{~K} / \mathrm{min}$ & 325.5 & 490.3 \\
\hline $2 \mathrm{~K} / \mathrm{min}$ & 326.8 & 490.0 \\
\hline Average & $325.5 \pm 7$ & $490.1 \pm 0.8$ \\
\hline
\end{tabular}

\subsubsection{INTEC B150}

INTEC B150 is the sixth of seven INTEC sample to be simulated in this study. Nearly $1,800 \mathrm{~kg}$ of heavy metal fuel was processed from the start of INTEC fuel processing to Batch 150 with $\sim 12 \mathrm{~kg}$ of heavy metal fuel processed per batch (Ref. 1,2). The composition of salt in the Mk-IV ER after the $150^{\text {th }}$ batch of INTEC fuel was processed and the composition of the $15 \mathrm{~g}$ simulated salt samples (INTEC B150) is: (1) $44.5 \mathrm{wt} \% \mathrm{LiCl}-\mathrm{KCl}$, (2) $8.5 \mathrm{wt} \% \mathrm{UCl}_{3}$, (3) $3.6 \mathrm{wt} \% \mathrm{PuCl}_{3}$, (4) $23.3 \mathrm{wt} \% \mathrm{NaCl}$, and (5) $20.0 \mathrm{wt} \% \mathrm{FP}$ chlorides. Figure 23 shows the DSC results of INTEC B150 with a $10 \mathrm{~K} / \mathrm{min}$ heating/cooling rate. From Figure 23, INTEC B150 has an onset temperature of $325.0 \pm 1.9^{\circ} \mathrm{C}$ and a liquidus temperature of $512.3 \pm 1.3^{\circ} \mathrm{C}$. The onset and liquidus temperatures will vary slightly with different heating rates; appendix E shows thermograms of multiple heating rates for INTEC B150. Table 14 shows the onset and liquidus temperature at $10 \mathrm{~K} / \mathrm{min}$ and $2 \mathrm{~K} / \mathrm{min}$ heating rates. 


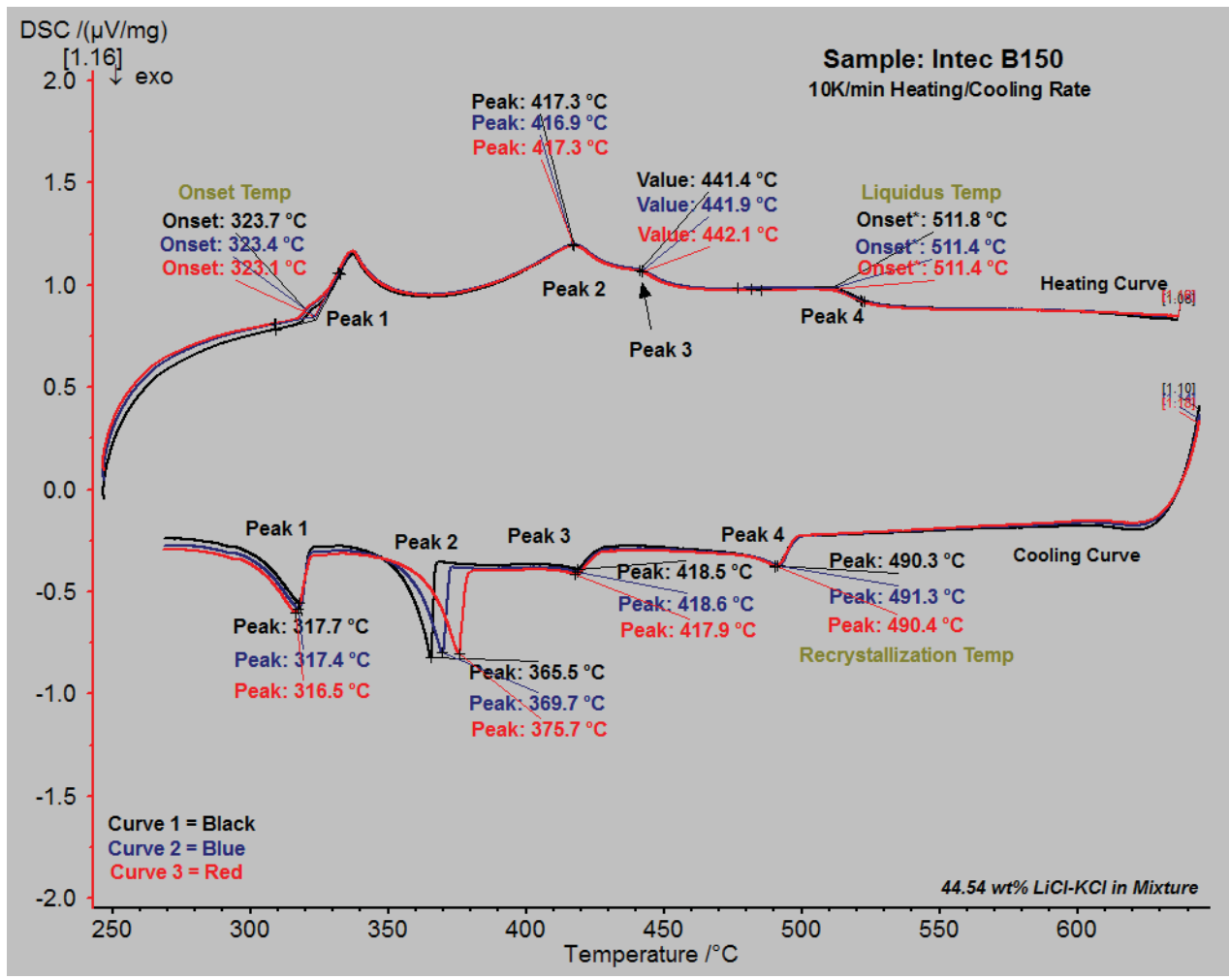

Figure $23.10 \mathrm{~K} / \mathrm{min}$ DSC curves of INTEC B150.

Table 14. Onset and liquidus temperatures at multiple heating rates for INTEC B150.

\begin{tabular}{|l|c|c|}
\cline { 2 - 3 } \multicolumn{1}{c|}{} & $\begin{array}{c}\text { Onset Temp, } \\
{ }^{\circ} \mathrm{C}\end{array}$ & $\begin{array}{c}\text { Liquidus Temp, } \\
{ }^{\circ} \mathrm{C}\end{array}$ \\
\hline $10 \mathrm{~K} / \mathrm{min}$ & 323.4 & 511.5 \\
\hline $2 \mathrm{~K} / \mathrm{min}$ & 326.5 & 513.1 \\
\hline Average & $325.0 \pm 1.9$ & $512.3 \pm 1.3$ \\
\hline
\end{tabular}

\subsubsection{INTEC B165}

INTEC B165 is the seventh and final INTEC sample to be simulated in this study. Nearly $2,000 \mathrm{~kg}$ of heavy metal fuel was processed from the start of INTEC fuel processing to batch 165 with $\sim 12 \mathrm{~kg}$ of heavy metal fuel processed per batch (Ref. 1,2). The composition of salt in the Mk-IV ER after the $165^{\text {th }}$ batch of INTEC fuel was processed and the composition of the $15 \mathrm{~g}$ simulated salt samples (INTEC B165) is: (1) $44.9 \mathrm{wt} \% \mathrm{LiCl}-\mathrm{KCl}$, (2) $9.8 \mathrm{wt} \% \mathrm{UCl}_{3}$, (3) $3.3 \mathrm{wt} \% \mathrm{PuCl}_{3}$, (4) $22.6 \mathrm{wt} \% \mathrm{NaCl}$, and (5) $19.4 \mathrm{wt} \% \mathrm{FP}$ chlorides. Figure 24 shows the DSC results of INTEC B165 with a $10 \mathrm{~K} / \mathrm{min}$ heating/cooling rate. From Figure 24, INTEC B165 has an onset temperature of $312.5 \pm 6.6^{\circ} \mathrm{C}$ and a liquidus temperature of $507.8 \pm 1.8^{\circ} \mathrm{C}$. The onset and liquidus temperatures will vary slightly with different heating rates; appendix E shows thermograms of multiple heating rates for INTEC B165. Table 15 shows the onset and liquidus temperature at $10 \mathrm{~K} / \mathrm{min}$ and $2 \mathrm{~K} / \mathrm{min}$ heating rates. 


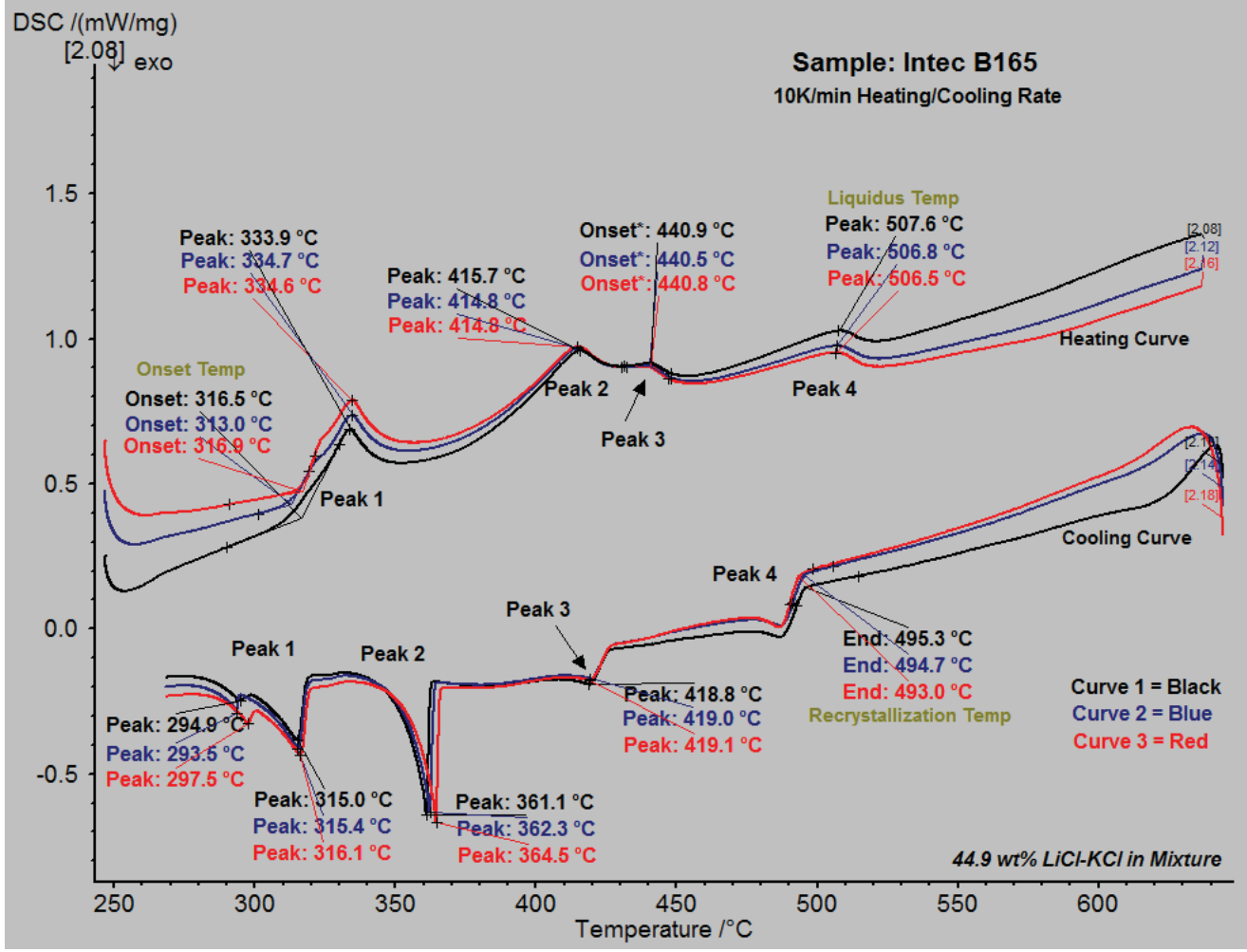

Figure 24. $10 \mathrm{~K} / \mathrm{min}$ DSC curves of INTEC B165.

Table 15. Onset and liquidus temperatures at multiple heating rates for INTEC B165.

\begin{tabular}{|l|c|c|}
\cline { 2 - 3 } \multicolumn{1}{c|}{} & $\begin{array}{c}\text { Onset Temp, } \\
{ }^{\circ} \mathrm{C}\end{array}$ & $\begin{array}{c}\text { Liquidus Temp, } \\
{ }^{\circ} \mathrm{C}\end{array}$ \\
\hline $10 \mathrm{~K} / \mathrm{min}$ & 315.5 & 507.0 \\
\hline $2 \mathrm{~K} / \mathrm{min}$ & 309.4 & 508.5 \\
\hline Average & $312.5 \pm 6.6$ & $507.8 \pm 1.8$ \\
\hline
\end{tabular}

At the beginning of FFTF fuel processing, the Mk-IV ER salt had a melting temperature of $378^{\circ} \mathrm{C}$; by the end of INTEC fuel processing, the melting temperature of the salt had risen $134^{\circ} \mathrm{C}$ to $512^{\circ} \mathrm{C}$. Figure 25 shows the liquidus and onset temperature vs. the impurity concentration in the salt. Currently, the Mk-IV operates at $500^{\circ} \mathrm{C}$. From Figure 25 it can be determined that once the impurity concentration of the salt becomes greater than $35 \mathrm{wt} \%$, the liquidus temperature will be greater than $400^{\circ} \mathrm{C}$ as indicated by any value above the red line. This occurs after Batch 25 of INTEC fuel is processed. Values in Figure 25 were taken from Tables 8 through 15 . The onset temperature decreases as the impurity concentration in the salt increases, this decreasing trend can be seen in Figure 25. 


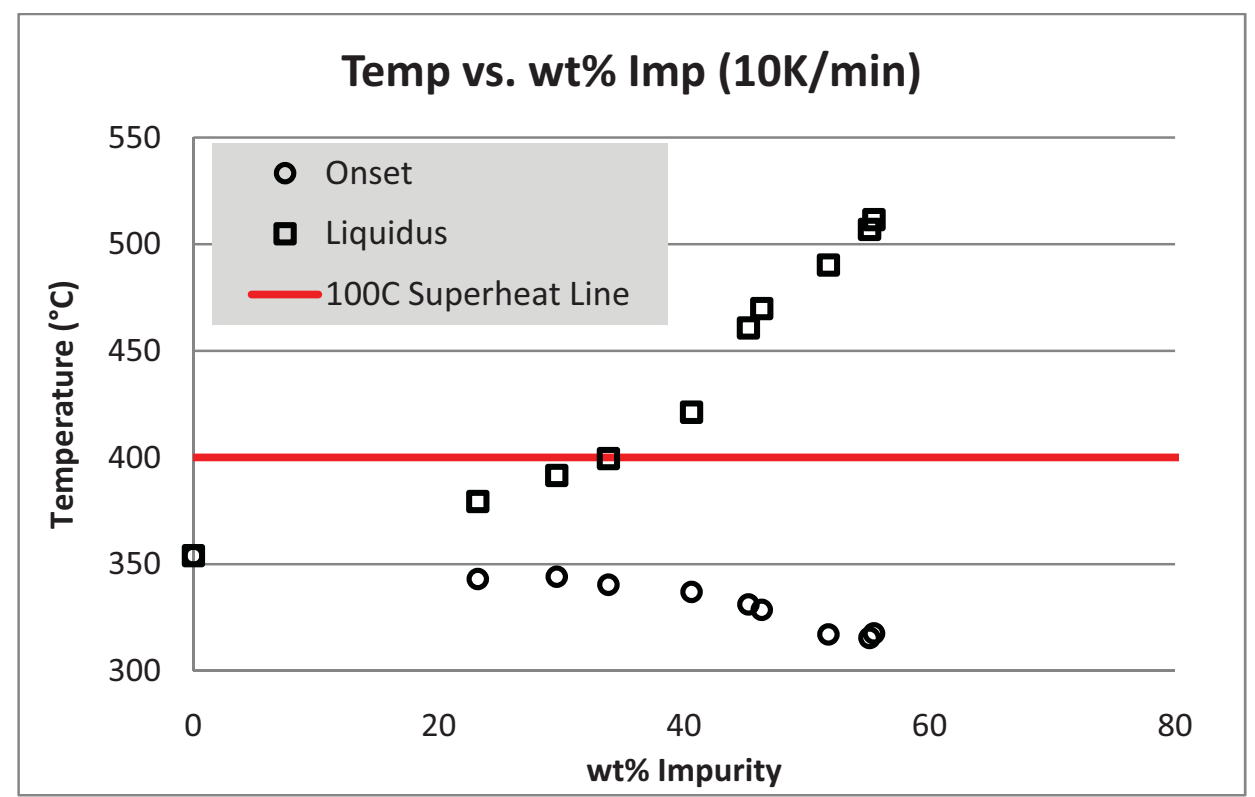

Figure 25. Liquidus and onset temperature as a function of impurity concentration in simulated salt sample. 


\section{CONCLUSION}

As the $\mathrm{wt} \%$ of impurities increase (actinide, fission product, and bond sodium) the liquidus temperature increases. This general trend was expected, but the exact nature of the trend, as a function of type and mass of spent fuel processed in the Mk-IV ER, was previously unknown. This study is a first of its kind to investigate the effects of electrorefining operations on the thermal characteristics of the electrolyte.

From this study it can be concluded that in order to maintain a $100^{\circ} \mathrm{C}$ of superheat (defined as the difference between operating temperature and liquidus temperature) the impurity concentration cannot be over $35 \mathrm{wt} \%$. The concentration of the salt would reach $35 \mathrm{wt} \%$ impurities after Batch 25 of INTEC fuel is processed. At the time the impurity concentration in the salt nears $35 \mathrm{wt} \%$ it may be necessary to remove and replace some of the electrolyte to reduce the impurity concentration. Using the information obtained from this research allows the INL to predict when salt removal will become necessary to support electrorefining operations. The salt removed from the Mk-IV ER will be incorporated into a ceramic waste form suitable for disposition into a geologic repository.

\section{PATH FORWARD}

This study has provided a strong foundation for similar research. There are still a few items that need to be finalized with regard to this study before proceeding. Inductively coupled plasma mass spectrometry (ICP-MS) will be used to analyze some of the simulated salt samples to confirm the concentration of metals (LiCl-KCl, FP, Na, and actinides) present in the simulated salt sample. The ICP-MS has the ability to detect metal concentrations below ten parts per billion and would determine if the simulated salt sample became contaminated during preparation or during DSC analysis.

A final instrument calibration will be run using the same calibration standards as the initial calibration:

- Benzoic Acid $\left(\mathrm{C}_{6} \mathrm{H}_{5} \mathrm{COOH}\right)$

- Rubidium Nitrate $\left(\mathrm{RbNO}_{3}\right)$

- Potassium Perchlorate $\left(\mathrm{KClO}_{4}\right)$

- Cesium Chloride $(\mathrm{CsCl})$

- Potassium Chromate $\left(\mathrm{K}_{2} \mathrm{CrO}_{4}\right)$.

The final calibration will show that the instrument is still in good operating condition and it remained that way during the duration of this study.

Having done research using non-radiological samples (this study) will provide insight on the behavior of the salt samples when radiological components are used (future study). The next set of experiments will be setup the same way as this study but $\mathrm{UCl}_{3}$ and $\mathrm{PuCl}_{3}$ will be used in the simulated salt samples. A new Netzsch STA instrument was purchased for use in a glovebox and is shown in Figure 26. It is currently located in the WCL, for setup and installation of new furnaces and to make sure it is operating correctly, but will be moved to an actinide glovebox in Building 752 at MFC. Since the new instrument will be located in an actinide glovebox, studies or development of phase diagrams pertinent to pyroprocessing can be developed. Systems of interest for pyroprocessing include: $\mathrm{LiCl}-\mathrm{KCl}-\mathrm{UCl}_{3}, \mathrm{LiCl}-\mathrm{KCl}-\mathrm{PuCl}_{3}$, $\mathrm{LiCl}-\mathrm{KCl}-\mathrm{NpCl}_{3}$, etc. There are very few studies on the $\mathrm{LiCl}-\mathrm{KCl}-\mathrm{UCl}_{3}$ ternary system and no studies on the ternary chloride system with transuranic elements; these are fundamental studies that need to be investigated. 


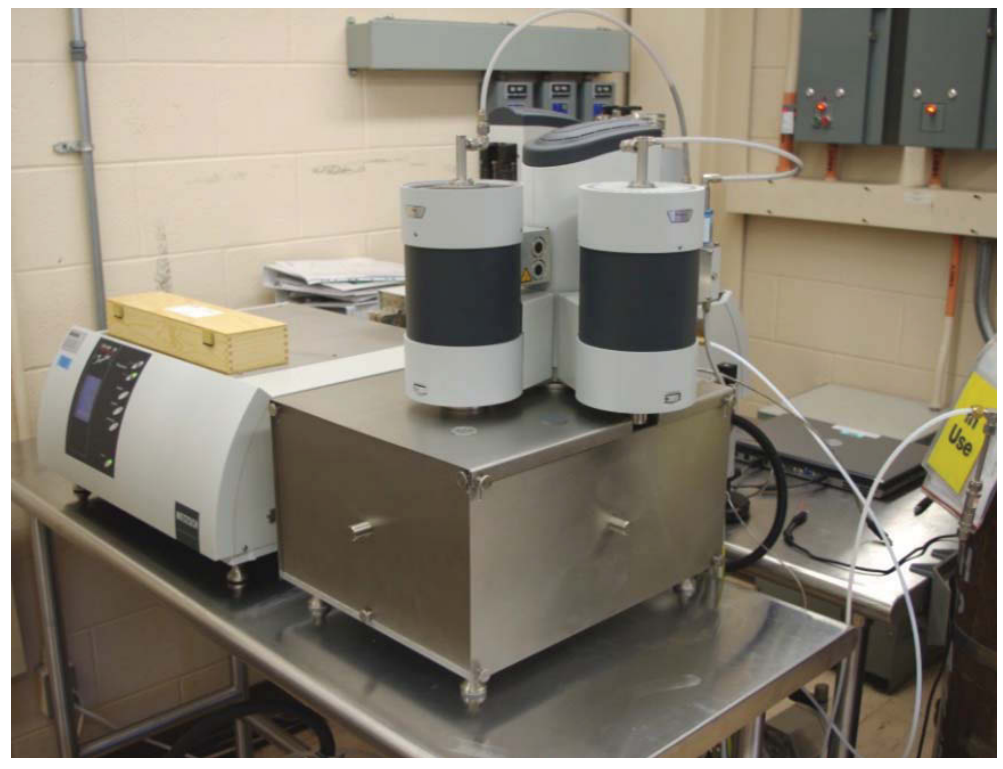

Figure 26. Glovebox ready Netzsch STA 449 F3 instrument. 


\section{REFERENCES}

1. Tae-Sic Yoo, Pyroprocessing Technology Department, Idaho National Laboratory, May 2010.

2. DeeEarl Vaden, Pyroprocessing Technology Department, Idaho National Laboratory, May 2010.

3. G.W.H. Hohne, W. Hemminger, and H. J. Flammersheim, Differential Scanning Calorimetry, $2^{\text {nd }}$ Ed., New York: Springer-Verlag Berlin Heidelberg, 2003.

4. E. Korin and L. Soifer, "Thermal Analysis of the System KCL-LiCI by Differential Scanning Calorimetry," Journal of Thermal Analysis, Vol. 50, No. 1, 1997, pp. 347-354. 


\section{Appendix A}

\section{Surrogate Mk-IV Salt Compositions}


Table A-1. Composition of Mk-IV salt and $15 \mathrm{~g}$ surrogate sample before FFTF fuel processing.

\begin{tabular}{|c|c|c|c|c|c|c|c|}
\hline $\begin{array}{l}\text { Before } \\
\text { FFTF }\end{array}$ & Element & $\begin{array}{l}\text { wt of Me in } \\
\text { Mk-IV salt }\end{array}$ & $\begin{array}{c}\% \mathrm{Me} \text { in } \\
\text { Mk-IV salt }\end{array}$ & $\begin{array}{c}\text { Calculated } \\
\text { weight of } \\
\mathrm{MeCl}_{\mathrm{x}} \text { for } \\
15 \mathrm{~g} \\
\text { Surrogate } \\
\text { Sample }\end{array}$ & $\begin{array}{c}\text { Actual } \\
\text { wt of } \\
\mathrm{MeCl}_{\mathrm{x}} \text { in } \\
15 \mathrm{~g} \\
\text { Sample }\end{array}$ & $\begin{array}{c}\text { Actual } \\
\text { wt of Me } \\
\text { in } 15 \mathrm{~g} \\
\text { Sample }\end{array}$ & $\begin{array}{l}\mathrm{wt} \% \mathrm{Me} \text { in } \\
15 \mathrm{~g} \text { sample }\end{array}$ \\
\hline 1 & Chlorine & 268417.70 & & & & & \\
\hline 2 & Potassium & 96705.37 & $55.09 \%$ & 6.3030 & 6.3030 & 3.3055 & $55.10 \%$ \\
\hline 3 & Lithium & 25011.34 & $14.25 \%$ & 5.2218 & 5.2231 & 0.8551 & $14.25 \%$ \\
\hline 4 & Uranium $(\mathrm{Gd})$ & 19897.29 & $11.34 \%$ & 1.1402 & 1.1402 & 0.6801 & $11.34 \%$ \\
\hline 5 & Sodium & 14330.03 & $8.16 \%$ & 1.2453 & 1.2455 & 0.4899 & $8.17 \%$ \\
\hline 6 & Neodymium & 4622.14 & $2.63 \%$ & 0.2742 & 0.2732 & 0.1574 & $2.62 \%$ \\
\hline 7 & Cesium & 4283.10 & $2.44 \%$ & 0.1850 & 0.1862 & 0.1474 & $2.46 \%$ \\
\hline 8 & Plutonium (Gd) & 3705.82 & $2.11 \%$ & 0.2124 & 0.2123 & 0.1266 & $2.11 \%$ \\
\hline 9 & Cerium & 2431.27 & $1.39 \%$ & 0.1459 & 0.1476 & 0.0841 & $1.40 \%$ \\
\hline 10 & Lanthanum & 1397.65 & $0.80 \%$ & 0.0844 & 0.0844 & 0.0478 & $0.80 \%$ \\
\hline 11 & Praseodymium & 1245.51 & $0.71 \%$ & 0.0747 & 0.0748 & 0.0426 & $0.71 \%$ \\
\hline 12 & Samarium & 1149.16 & $0.65 \%$ & 0.0674 & 0.0585 & 0.0341 & $0.57 \%$ \\
\hline 13 & Strontium & 746.74 & $0.43 \%$ & 0.0459 & 0.0514 & 0.0286 & $0.48 \%$ \\
\hline \multicolumn{2}{|l|}{ Total } & 443943.12 & $100.00 \%$ & 15.0000 & 15.0002 & 5.9994 & $100.00 \%$ \\
\hline
\end{tabular}

Table A-2. Composition of Mk-IV salt and $15 \mathrm{~g}$ surrogate sample after FFTF fuel processing.

\begin{tabular}{|c|c|c|c|c|c|c|c|}
\hline $\begin{array}{l}\text { After } \\
\text { FFTF }\end{array}$ & Element & $\begin{array}{l}\text { wt of Me in } \\
\text { Mk-IV salt }\end{array}$ & $\begin{array}{c}\% \text { Me in } \\
\text { Mk-IV salt }\end{array}$ & $\begin{array}{c}\text { Calculated } \\
\text { weight of } \\
\mathrm{MeCl}_{\mathrm{x}} \text { for } \\
15 \mathrm{~g} \\
\text { Surrogate } \\
\text { Sample }\end{array}$ & $\begin{array}{l}\text { Actual wt } \\
\text { of } \mathrm{MeCl}_{\mathrm{x}} \\
\text { in } 15 \mathrm{~g} \\
\text { Sample }\end{array}$ & $\begin{array}{l}\text { Actual } \\
\text { wt of Me } \\
\text { in } 15 \mathrm{~g} \\
\text { Sample }\end{array}$ & $\begin{array}{l}\mathrm{wt} \% \mathrm{Me} \text { in } \\
15 \mathrm{~g} \text { sample }\end{array}$ \\
\hline 1 & Chlorine & 258704.69 & & & NA & & \\
\hline 2 & Potassium & 87870.12 & $48.78 \%$ & 5.7638 & 5.7638 & 3.0239 & $48.70 \%$ \\
\hline 3 & Lithium & 22724.54 & $12.61 \%$ & 4.7733 & 4.7943 & 0.7855 & $12.65 \%$ \\
\hline 4 & Uranium (Gd) & 21827.91 & $12.12 \%$ & 1.2589 & 1.2614 & 0.7527 & $12.12 \%$ \\
\hline 5 & Sodium & 16044.06 & $8.91 \%$ & 1.4030 & 1.4059 & 0.5533 & $8.91 \%$ \\
\hline 6 & Plutonium (Gd) & 9555.20 & $5.30 \%$ & 0.5511 & 0.5521 & 0.3294 & $5.31 \%$ \\
\hline 7 & Neodymium & 6940.88 & $3.85 \%$ & 0.4143 & 0.2977 & 0.1716 & $2.76 \%$ \\
\hline 8 & Cesium & 4814.50 & $2.67 \%$ & 0.2093 & 0.2971 & 0.2352 & $3.79 \%$ \\
\hline 9 & Cerium & 3765.47 & $2.09 \%$ & 0.2274 & 0.2279 & 0.1299 & $2.09 \%$ \\
\hline 10 & Lanthanum & 2101.88 & $1.17 \%$ & 0.1277 & 0.1279 & 0.0725 & $1.17 \%$ \\
\hline 11 & Praseodymium & 1917.06 & $1.06 \%$ & 0.1157 & 0.1161 & 0.0662 & $1.07 \%$ \\
\hline 12 & Samarium & 1671.39 & $0.93 \%$ & 0.0987 & 0.0987 & 0.0575 & $0.93 \%$ \\
\hline 13 & Strontium & 919.13 & $0.51 \%$ & 0.0568 & 0.0572 & 0.0318 & $0.51 \%$ \\
\hline \multicolumn{2}{|l|}{ Total } & 438856.83 & $100.00 \%$ & 15.0000 & 15.0001 & 6.2094 & $100.00 \%$ \\
\hline
\end{tabular}


Table A-3. Composition of Mk-IV salt and $15 \mathrm{~g}$ surrogate sample after INTEC B25.

\begin{tabular}{|c|l|c|c|c|c|c|c|}
\hline $\begin{array}{c}\text { INTEC } \\
\text { B25 }\end{array}$ & \multicolumn{1}{|c|}{ Element } & $\begin{array}{c}\text { Wt of Me in } \\
\text { Mk-IV salt }\end{array}$ & $\begin{array}{c}\text { Calculated } \\
\text { weight of } \\
\text { Mk-IV salt }\end{array}$ & $\begin{array}{c}\text { MeCl for } 15 \mathrm{~g} \\
\text { Surrogate } \\
\text { Sample }\end{array}$ & $\begin{array}{c}\text { Actual wt } \\
\text { of MeCl } \\
\text { in } 15 \mathrm{~g} \\
\text { Sample }\end{array}$ & $\begin{array}{c}\text { Actual wt } \\
\text { of Me in } \\
15 \mathrm{~g} \\
\text { Sample }\end{array}$ & $\begin{array}{c}\text { wt\% Me in } \\
\text { S sample }\end{array}$ \\
\hline 1 & Chlorine & 258091.64 & & & & & \\
\hline 2 & Potassium & 84430.762 & $45.35 \%$ & 5.4400 & 5.4400 & 2.8617 & $45.36 \%$ \\
\hline 3 & Uranium (Gd) & 24290.255 & $13.05 \%$ & 1.3760 & 1.3760 & 0.8233 & $13.05 \%$ \\
\hline 4 & Lithium & 21869.152 & $11.75 \%$ & 4.4871 & 4.4869 & 0.7412 & $11.75 \%$ \\
\hline 5 & Sodium & 19641.454 & $10.55 \%$ & 1.6848 & 1.6851 & 0.6658 & $10.55 \%$ \\
\hline 6 & Plutonium (Gd) & 8790.6774 & $4.72 \%$ & 0.4980 & 0.4975 & 0.2977 & $4.72 \%$ \\
\hline 7 & Neodymium & 7895.5492 & $4.24 \%$ & 0.4629 & 0.4629 & 0.2676 & $4.24 \%$ \\
\hline 8 & Cesium & 5623.9491 & $3.02 \%$ & 0.2405 & 0.2404 & 0.1905 & $3.02 \%$ \\
\hline 9 & Cerium & 4373.5367 & $2.35 \%$ & 0.2593 & 0.2592 & 0.1482 & $2.35 \%$ \\
\hline 10 & Lanthanum & 2396.3796 & $1.29 \%$ & 0.1430 & 0.1434 & 0.0815 & $1.29 \%$ \\
\hline 11 & Praseodymium & 2210.1174 & $1.19 \%$ & 0.1310 & 0.1312 & 0.0750 & $1.19 \%$ \\
\hline 12 & Samarium & 1807.3677 & $0.97 \%$ & 0.1048 & 0.1044 & 0.0610 & $0.97 \%$ \\
\hline 13 & Barium (Sr) & 1667.7765 & $0.90 \%$ & 0.1019 & 0.1019 & 0.0565 & $0.90 \%$ \\
\hline 14 & Strontium & 1161.393 & $0.62 \%$ & 0.0706 & 0.0708 & 0.0395 & $0.63 \%$ \\
\hline Total & & $\mathbf{4 4 4 2 5 0 . 0 1}$ & $\mathbf{1 0 0 . 0 0 \%}$ & $\mathbf{1 5 . 0 0 0 0}$ & $\mathbf{1 4 . 9 9 9 7}$ & $\mathbf{6 . 3 0 9 4}$ & $\mathbf{1 0 0 . 0 0 \%}$ \\
\hline
\end{tabular}

Table A-4: Composition of Mk-IV salt and $15 \mathrm{~g}$ surrogate sample after INTEC B50

\begin{tabular}{|c|c|c|c|c|c|c|c|}
\hline $\begin{array}{c}\text { INTEC } \\
\text { B50 }\end{array}$ & Element & $\begin{array}{l}\text { wt of Me in } \\
\text { Mk-IV salt }\end{array}$ & $\begin{array}{c}\% \text { Me in } \\
\text { Mk-IV salt }\end{array}$ & $\begin{array}{c}\text { Calculated } \\
\text { weight of } \\
\mathrm{MeCl}_{\mathrm{x}} \text { for } \\
15 \mathrm{~g} \\
\text { Surrogate } \\
\text { Sample }\end{array}$ & $\begin{array}{c}\text { Actual } \\
\text { wt of } \\
\mathrm{MeCl}_{\mathrm{x}} \text { in } \\
15 \mathrm{~g} \\
\text { Sample }\end{array}$ & $\begin{array}{l}\text { Actual } \\
\text { wt of Me } \\
\text { in } 15 \mathrm{~g} \\
\text { Sample }\end{array}$ & $\begin{array}{l}\mathrm{wt} \% \mathrm{Me} \text { in } \\
15 \mathrm{~g} \text { sample }\end{array}$ \\
\hline 1 & Chlorine & 257233.89 & & & & & \\
\hline 2 & Potassium & 77241.503 & $39.77 \%$ & 4.8766 & 4.8766 & 2.5617 & $39.77 \%$ \\
\hline 3 & Uranium $(\mathrm{Gd})$ & 27436.795 & $14.13 \%$ & 1.5230 & 1.5228 & 0.9098 & $14.12 \%$ \\
\hline 4 & Sodium & 25622.72 & $13.19 \%$ & 2.1551 & 2.1547 & 0.8496 & $13.19 \%$ \\
\hline 5 & Lithium & 20006.999 & $10.30 \%$ & 4.0336 & 4.0336 & 0.6635 & $10.30 \%$ \\
\hline 6 & Neodymium & 9833.3565 & $5.06 \%$ & 0.5649 & 0.5649 & 0.3261 & $5.06 \%$ \\
\hline 7 & Plutonium (Gd) & 9213.2646 & $4.74 \%$ & 0.5114 & 0.5114 & 0.3055 & $4.74 \%$ \\
\hline 8 & Cesium & 7116.5501 & $3.66 \%$ & 0.2980 & 0.2982 & 0.2362 & $3.67 \%$ \\
\hline 9 & Cerium & 5522.1838 & $2.84 \%$ & 0.3209 & 0.3214 & 0.1834 & $2.85 \%$ \\
\hline 10 & Lanthanum & 2989.0321 & $1.54 \%$ & 0.1747 & 0.1749 & 0.0992 & $1.54 \%$ \\
\hline 11 & Praseodymium & 2777.0663 & $1.43 \%$ & 0.1613 & 0.1611 & 0.0920 & $1.43 \%$ \\
\hline 12 & $\operatorname{Barium}(\mathrm{Sr})$ & 2765.1073 & $1.42 \%$ & 0.1656 & 0.1656 & 0.0917 & $1.42 \%$ \\
\hline 13 & Samarium & 2171.9301 & $1.12 \%$ & 0.1234 & 0.1237 & 0.0722 & $1.12 \%$ \\
\hline 14 & Strontium & 1535.999 & $0.79 \%$ & 0.0914 & 0.0914 & 0.0509 & $0.79 \%$ \\
\hline \multicolumn{2}{|l|}{ Total } & 451466.40 & $100.00 \%$ & 15.0000 & 15.0003 & 6.4420 & $100.00 \%$ \\
\hline
\end{tabular}


Table A-5. Composition of Mk-IV salt and $15 \mathrm{~g}$ surrogate sample after INTEC B75.

\begin{tabular}{|c|c|c|c|c|c|c|c|}
\hline $\begin{array}{c}\text { INTEC } \\
\text { B75 }\end{array}$ & Element & $\begin{array}{l}\text { wt of Me in } \\
\text { Mk-IV salt }\end{array}$ & $\begin{array}{c}\% \text { Me in } \\
\text { Mk-IV salt }\end{array}$ & $\begin{array}{c}\text { Calculated } \\
\text { weight of } \\
\mathrm{MeCl}_{\mathrm{x}} \text { for } \\
15 \mathrm{~g} \\
\text { Surrogate } \\
\text { Sample }\end{array}$ & $\begin{array}{c}\text { Actual } \\
\text { wt of } \\
\mathrm{MeCl}_{\mathrm{x}} \text { in } \\
15 \mathrm{~g} \\
\text { Sample }\end{array}$ & $\begin{array}{c}\text { Actual } \\
\text { wt of Me } \\
\text { in } 15 \mathrm{~g} \\
\text { Sample }\end{array}$ & $\begin{array}{l}\mathrm{wt} \% \mathrm{Me} \text { in } \\
15 \mathrm{~g} \text { sample }\end{array}$ \\
\hline 1 & Chlorine & 253591.18 & & & & & \\
\hline 2 & Potassium & 70717.12 & $36.28 \%$ & 4.4964 & 4.4964 & 2.3628 & $36.28 \%$ \\
\hline 3 & Sodium & 31115.06 & $15.96 \%$ & 2.6355 & 2.6351 & 1.0395 & $15.96 \%$ \\
\hline 4 & Uranium & 23493.69 & $12.05 \%$ & 1.3135 & 1.3135 & 0.7850 & $12.05 \%$ \\
\hline 5 & Lithium & 18317.06 & $9.40 \%$ & 3.7182 & 3.7179 & 0.6120 & $9.40 \%$ \\
\hline 6 & Neodymium & 11613.86 & $5.96 \%$ & 0.6720 & 0.6718 & 0.3879 & $5.96 \%$ \\
\hline 7 & Plutonium & 9606.56 & $4.93 \%$ & 0.5371 & 0.5365 & 0.3206 & $4.92 \%$ \\
\hline 8 & Cesium & 8472.98 & $4.35 \%$ & 0.3574 & 0.3578 & 0.2834 & $4.35 \%$ \\
\hline 9 & Cerium & 6577.37 & $3.37 \%$ & 0.3849 & 0.3850 & 0.2198 & $3.38 \%$ \\
\hline 10 & Barium $(\mathrm{Sr})$ & 3786.03 & $1.94 \%$ & 0.2284 & 0.2284 & 0.1265 & $1.94 \%$ \\
\hline 11 & Lanthanum & 3533.56 & $1.81 \%$ & 0.2080 & 0.2080 & 0.1180 & $1.81 \%$ \\
\hline 12 & Praseodymium & 3297.92 & $1.69 \%$ & 0.1930 & 0.1933 & 0.1104 & $1.69 \%$ \\
\hline 13 & Samarium & 2506.47 & $1.29 \%$ & 0.1435 & 0.1434 & 0.0837 & $1.29 \%$ \\
\hline 14 & Strontium & 1871.12 & $0.96 \%$ & 0.1122 & 0.1123 & 0.0626 & $0.96 \%$ \\
\hline \multicolumn{2}{|l|}{ Total } & 448500.00 & $100.00 \%$ & 15.0000 & 14.9994 & 6.5122 & $100.00 \%$ \\
\hline
\end{tabular}

Table A-6. Composition of Mk-IV salt and $15 \mathrm{~g}$ surrogate sample after INTEC B100.

\begin{tabular}{|c|c|c|c|c|c|c|c|}
\hline $\begin{array}{c}\text { INTEC } \\
\text { B100 }\end{array}$ & Element & $\begin{array}{l}\text { wt of Me in } \\
\text { Mk-IV salt }\end{array}$ & $\begin{array}{c}\% \text { Me in } \\
\text { Mk-IV salt }\end{array}$ & $\begin{array}{c}\text { Calculated } \\
\text { weight of } \\
\mathrm{MeCl}_{\mathrm{x}} \text { for } \\
15 \mathrm{~g} \\
\text { Surrogate } \\
\text { Sample } \\
\end{array}$ & $\begin{array}{c}\text { Actual wt } \\
\text { of } \mathrm{MeCl}_{\mathrm{x}} \text { in } \\
15 \mathrm{~g} \\
\text { Sample }\end{array}$ & $\begin{array}{c}\text { Actual wt } \\
\text { of Me in } \\
15 \mathrm{~g} \\
\text { Sample }\end{array}$ & $\begin{array}{c}\mathrm{wt} \% \mathrm{Me} \text { in } \\
15 \mathrm{~g} \\
\text { sample }\end{array}$ \\
\hline 1 & Chlorine & 252243.85 & & & & & \\
\hline 2 & Potassium & 69470.65 & $35.48 \%$ & 4.4089 & 4.4089 & 2.3181 & $35.47 \%$ \\
\hline 3 & Sodium & 32453.71 & $16.57 \%$ & 2.7425 & 2.7432 & 1.0832 & $16.58 \%$ \\
\hline 4 & Uranium & 23860.55 & $12.18 \%$ & 1.3313 & 1.3313 & 0.7962 & $12.18 \%$ \\
\hline 5 & Lithium & 18020.70 & $9.20 \%$ & 3.6435 & 3.6436 & 0.6013 & $9.20 \%$ \\
\hline 6 & Neodymium & 11885.85 & $6.07 \%$ & 0.6863 & 0.6865 & 0.3967 & $6.07 \%$ \\
\hline 7 & Plutonium & 8919.75 & $4.55 \%$ & 0.4977 & 0.4975 & 0.2975 & $4.55 \%$ \\
\hline 8 & Cesium & 8708.50 & $4.45 \%$ & 0.3667 & 0.3664 & 0.2903 & $4.44 \%$ \\
\hline 9 & Cerium & 6770.95 & $3.46 \%$ & 0.3955 & 0.3956 & 0.2260 & $3.46 \%$ \\
\hline 10 & Barium (Sr) & 4258.20 & $2.17 \%$ & 0.2564 & 0.2563 & 0.1421 & $2.17 \%$ \\
\hline 11 & Lanthanum & 3618.68 & $1.85 \%$ & 0.2126 & 0.2126 & 0.1207 & $1.85 \%$ \\
\hline 12 & Praseodymium & 3388.04 & $1.73 \%$ & 0.1979 & 0.1982 & 0.1133 & $1.73 \%$ \\
\hline 13 & Samarium & 2522.66 & $1.29 \%$ & 0.1441 & 0.1446 & 0.0845 & $1.29 \%$ \\
\hline 14 & Strontium & 1948.74 & $1.00 \%$ & 0.1166 & 0.1167 & 0.0651 & $1.00 \%$ \\
\hline \multicolumn{2}{|l|}{ Total } & 448070.84 & $100.00 \%$ & 15.0000 & 15.0014 & 6.5349 & $100.00 \%$ \\
\hline
\end{tabular}


Table A-7. Composition of Mk-IV salt and $15 \mathrm{~g}$ surrogate sample after INTEC B125.

\begin{tabular}{|c|c|c|c|c|c|c|c|}
\hline $\begin{array}{c}\text { INTEC } \\
\text { B125 } \\
\end{array}$ & Element & $\begin{array}{l}\text { wt of Me in } \\
\text { Mk-IV salt }\end{array}$ & $\begin{array}{c}\% \text { Me in } \\
\text { Mk-IV salt }\end{array}$ & $\begin{array}{c}\text { Calculated } \\
\text { weight of } \\
\mathrm{MeCl}_{\mathrm{x}} \text { for } \\
15 \mathrm{~g} \\
\text { Surrogate } \\
\text { Sample } \\
\end{array}$ & $\begin{array}{c}\text { Actual } \\
\text { wt of } \\
\mathrm{MeCl}_{\mathrm{x}} \text { in } \\
15 \mathrm{~g} \\
\text { Sample }\end{array}$ & $\begin{array}{c}\text { Actual } \\
\text { wt of Me } \\
\text { in } 15 \mathrm{~g} \\
\text { Sample }\end{array}$ & $\begin{array}{l}\mathrm{wt} \% \mathrm{Me} \text { in } \\
15 \mathrm{~g} \text { sample }\end{array}$ \\
\hline 1 & Chlorine & 252152.88 & & & & & \\
\hline 2 & Potassium & 63634.61 & $31.31 \%$ & 3.9633 & 3.9633 & 2.0844 & $31.31 \%$ \\
\hline 3 & Sodium & 37386.00 & $18.40 \%$ & 3.1001 & 3.1002 & 1.2246 & $18.40 \%$ \\
\hline 4 & Uranium & 27011.76 & $13.29 \%$ & 1.4791 & 1.4791 & 0.8848 & $13.29 \%$ \\
\hline 5 & Lithium & 16506.83 & $8.12 \%$ & 3.2745 & 3.2748 & 0.5407 & $8.12 \%$ \\
\hline 6 & Neodymium & 13499.14 & $6.64 \%$ & 0.7650 & 0.7653 & 0.4423 & $6.64 \%$ \\
\hline 7 & Cesium & 9912.80 & $4.88 \%$ & 0.4097 & 0.4095 & 0.3245 & $4.87 \%$ \\
\hline 8 & Plutonium & 9342.22 & $4.60 \%$ & 0.5116 & 0.5119 & 0.3062 & $4.60 \%$ \\
\hline 9 & Cerium & 7724.17 & $3.80 \%$ & 0.4427 & 0.4429 & 0.2531 & $3.80 \%$ \\
\hline 10 & Barium & 5177.48 & $2.55 \%$ & 0.3059 & 0.3056 & 0.1694 & $2.55 \%$ \\
\hline 11 & Lanthanum & 4111.90 & $2.02 \%$ & 0.2371 & 0.2371 & 0.1347 & $2.02 \%$ \\
\hline 12 & Praseodymium & 3859.05 & $1.90 \%$ & 0.2212 & 0.2210 & 0.1263 & $1.90 \%$ \\
\hline 13 & Samarium & 2827.87 & $1.39 \%$ & 0.1586 & 0.1589 & 0.0928 & $1.39 \%$ \\
\hline 14 & Strontium & 2236.40 & $1.10 \%$ & 0.1313 & 0.1315 & 0.0733 & $1.10 \%$ \\
\hline \multicolumn{2}{|l|}{ Total } & 455383.10 & $100.00 \%$ & 15.0000 & 15.0011 & 6.6573 & $100.00 \%$ \\
\hline
\end{tabular}

Table A-8: Composition of Mk-IV salt and $15 \mathrm{~g}$ surrogate sample after INTEC B150

\begin{tabular}{|c|c|c|c|c|c|c|c|}
\hline $\begin{array}{l}\text { INTEC } \\
\text { B150 }\end{array}$ & Element & $\begin{array}{l}\text { wt of Me in } \\
\text { Mk-IV salt }\end{array}$ & $\begin{array}{l}\% \text { Me in } \\
\text { Mk-IV salt }\end{array}$ & $\begin{array}{l}\text { Calculated } \\
\text { weight of } \\
\mathrm{MeCl}_{\mathrm{x}} \text { for } \\
15 \mathrm{~g} \\
\text { Surrogate } \\
\text { Sample }\end{array}$ & $\begin{array}{l}\text { Actual } \\
\text { wt of } \\
\mathrm{MeCl}_{\mathrm{x}} \text { in } \\
15 \mathrm{~g} \\
\text { Sample }\end{array}$ & $\begin{array}{l}\text { Actual } \\
\text { wt of Me } \\
\text { in } 15 \mathrm{~g} \\
\text { Sample }\end{array}$ & $\begin{array}{l}\mathrm{wt} \% \mathrm{Me} \text { in } \\
15 \mathrm{~g} \text { sample }\end{array}$ \\
\hline 1 & Chlorine & 249193.83 & & & & & \\
\hline 2 & Potassium & 58326.54 & $28.69 \%$ & 3.6590 & 3.6590 & 1.9248 & $28.69 \%$ \\
\hline 3 & Sodium & 41928.58 & $20.62 \%$ & 3.5018 & 3.5015 & 1.3836 & $20.62 \%$ \\
\hline 4 & Uranium & 23094.75 & $11.36 \%$ & 1.2738 & 1.2738 & 0.7621 & $11.36 \%$ \\
\hline 5 & Lithium & 15129.91 & $7.44 \%$ & 3.0225 & 3.0224 & 0.4993 & $7.44 \%$ \\
\hline 6 & Neodymium & 14985.74 & $7.37 \%$ & 0.8554 & 0.8555 & 0.4946 & $7.37 \%$ \\
\hline 7 & Cesium & 11009.95 & $5.42 \%$ & 0.4584 & 0.4580 & 0.3630 & $5.41 \%$ \\
\hline 8 & Plutonium & 9735.06 & $4.79 \%$ & 0.5370 & 0.5372 & 0.3214 & $4.79 \%$ \\
\hline 9 & Cerium & 8602.38 & $4.23 \%$ & 0.4967 & 0.4966 & 0.2838 & $4.23 \%$ \\
\hline 10 & Barium $(\mathrm{Sr})$ & 6035.50 & $2.97 \%$ & 0.3592 & 0.3590 & 0.1991 & $2.97 \%$ \\
\hline 11 & Lanthanum & 4566.38 & $2.25 \%$ & 0.2652 & 0.2649 & 0.1505 & $2.24 \%$ \\
\hline 12 & Praseodymium & 4293.01 & $2.11 \%$ & 0.2478 & 0.2480 & 0.1418 & $2.11 \%$ \\
\hline 13 & Samarium & 3108.74 & $1.53 \%$ & 0.1756 & 0.1758 & 0.1027 & $1.53 \%$ \\
\hline 14 & Strontium & 2493.98 & $1.23 \%$ & 0.1476 & 0.1478 & 0.0824 & $1.23 \%$ \\
\hline \multicolumn{2}{|l|}{ Total } & 452504.36 & $100.00 \%$ & 15.0000 & 14.9995 & 6.7091 & $100.00 \%$ \\
\hline
\end{tabular}


Appendix B

Calibration of Stainless Steel

Gold Plated DSC Crucibles 


\section{B1. Benzoic Acid Standard}

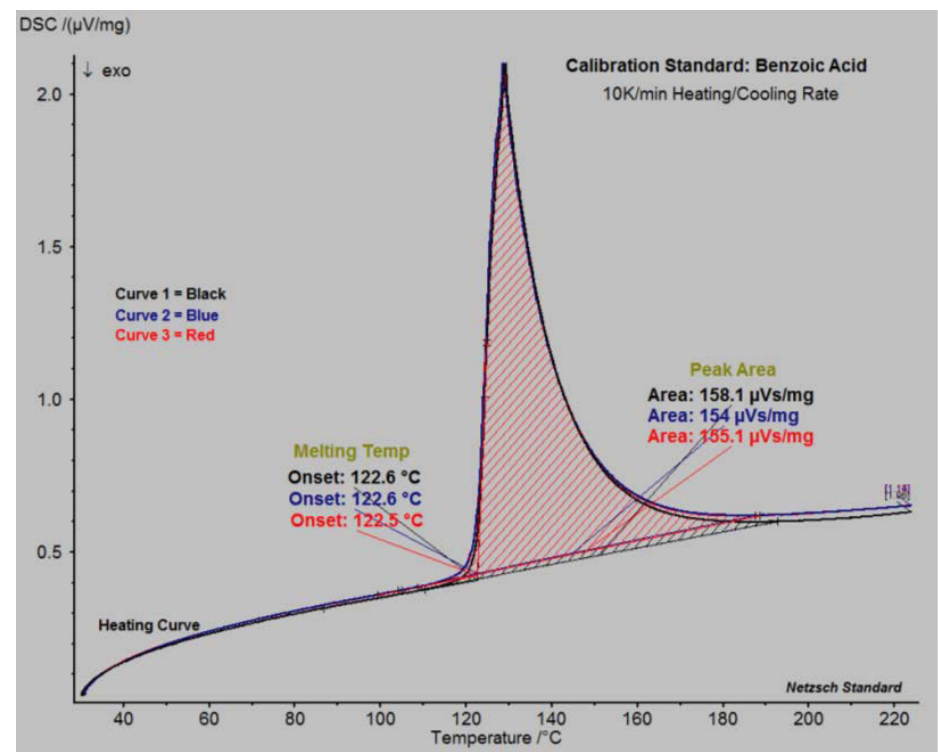

Figure B-1. $10 \mathrm{~K} / \mathrm{min}$ heating rate for the Benzoic Acid standard.

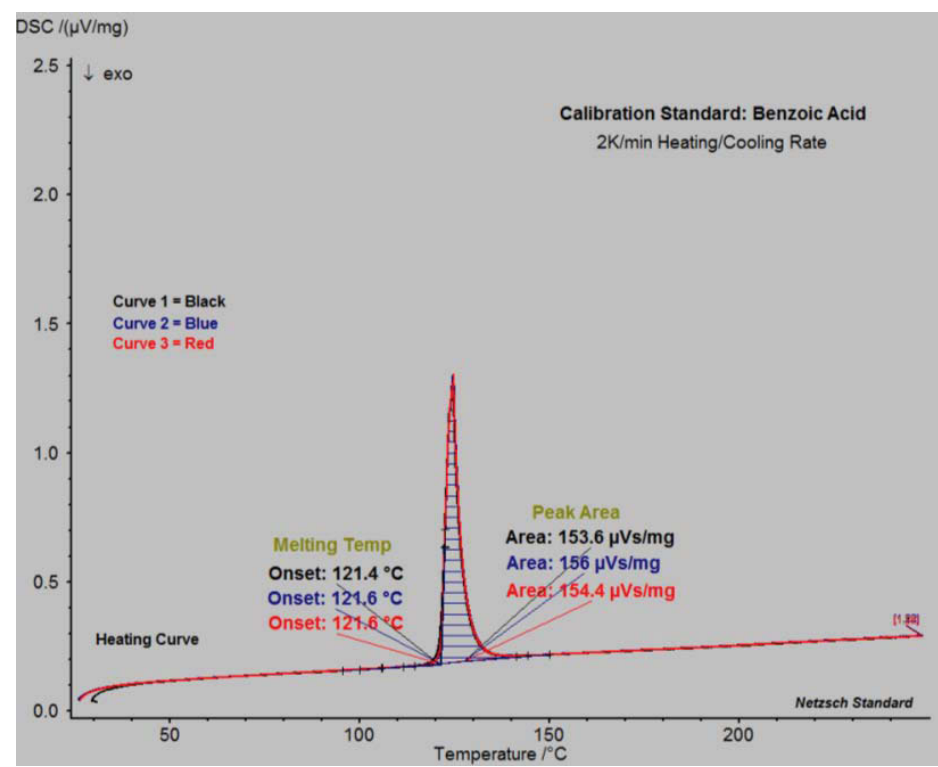

Figure B-2. $2 \mathrm{~K} / \mathrm{min}$ heating rate for the Benzoic Acid standard.

Table B-1. Onset and Peak values obtained from thermograms in Figure B-1 and B-2.

\begin{tabular}{|c|c|c|c|c|c|}
\hline \multicolumn{2}{|c|}{ Benzoic Acid Standard $\left(\mathrm{C}_{6} \mathrm{H}_{5} \mathrm{COOH}\right)$} & \multicolumn{3}{c|}{$2 \mathrm{~K} / \mathrm{min}$} \\
\hline & $\begin{array}{c}\text { Onset Temp, } \\
{ }^{\circ} \mathrm{C}\end{array}$ & $\begin{array}{c}\text { Peak Area, } \\
\mu \mathrm{Vs} / \mathrm{mg}\end{array}$ & $\begin{array}{c}\text { Onset Temp, } \\
{ }^{\circ} \mathrm{C}\end{array}$ & $\begin{array}{c}\text { Peak Area, } \\
\mu \text { Vs/mg }\end{array}$ \\
\hline 1 & 122.6 & 158.1 & 1 & 121.4 & 153.6 \\
\hline 2 & 122.6 & 154.0 & 2 & 121.6 & 156.0 \\
\hline 3 & 122.5 & 155.1 & 3 & 121.6 & 154.4 \\
\hline Avg & 122.6 & 155.7 & $\mathrm{Avg}$ & 121.5 & 154.7 \\
\hline
\end{tabular}




\section{B2. Rubidium Nitrate Standard}

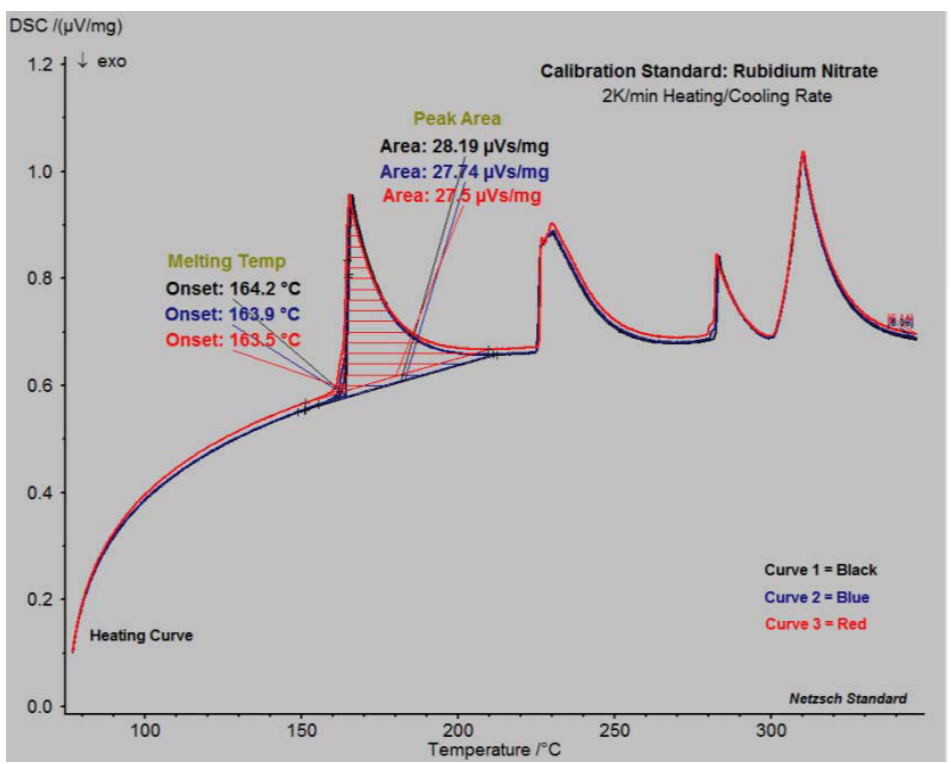

Figure B-3. $10 \mathrm{~K} / \mathrm{min}$ heating rate for the Rubidium Nitrate standard.

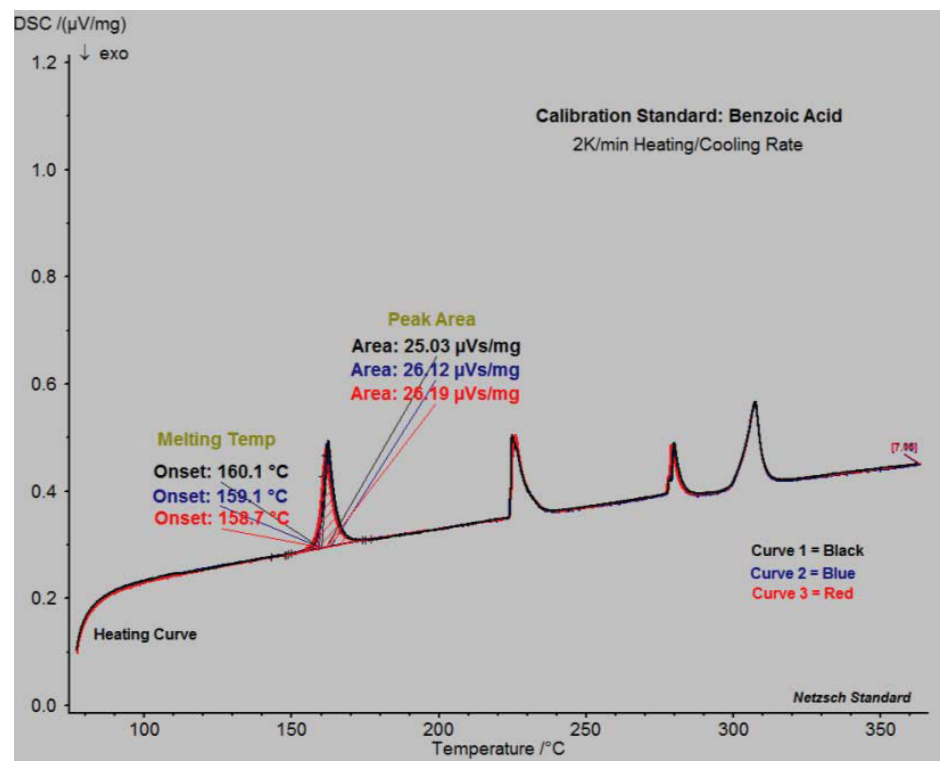

Figure B-4. $2 \mathrm{~K} / \mathrm{min}$ heating rate for the Rubidium Nitrate standard.

Table B-2. Onset and Peak values obtained from thermograms in Figure B-3 and B-4.

\begin{tabular}{|c|c|c|c|c|c|}
\hline \multicolumn{2}{|c|}{ Rubidium Nitrate Standard $\left(\mathrm{RbNO}_{3}\right)$} & \multicolumn{4}{c|}{$2 \mathrm{~K} / \mathrm{min}$} \\
\hline & $\begin{array}{c}\text { Onset Temp, } \\
{ }^{\circ} \mathrm{C}\end{array}$ & $\begin{array}{c}\text { Peak Area, } \\
\mu \mathrm{Vs} / \mathrm{mg}\end{array}$ & $\begin{array}{c}\text { Onset Temp, } \\
{ }^{\circ} \mathrm{C}\end{array}$ & $\begin{array}{c}\text { Peak Area, } \\
\mu \mathrm{Vs} / \mathrm{mg}\end{array}$ \\
\hline 1 & 164.2 & 28.19 & 1 & 160.1 & 25.03 \\
\hline 2 & 163.9 & 27.74 & 2 & 159.1 & 26.12 \\
\hline 3 & 163.5 & 27.5 & 3 & 158.7 & 26.18 \\
\hline Avg & 163.8 & 27.8 & $\mathrm{Avg}$ & 159.3 & 25.8 \\
\hline
\end{tabular}




\section{B3. Potassium Perchlorate Standard}

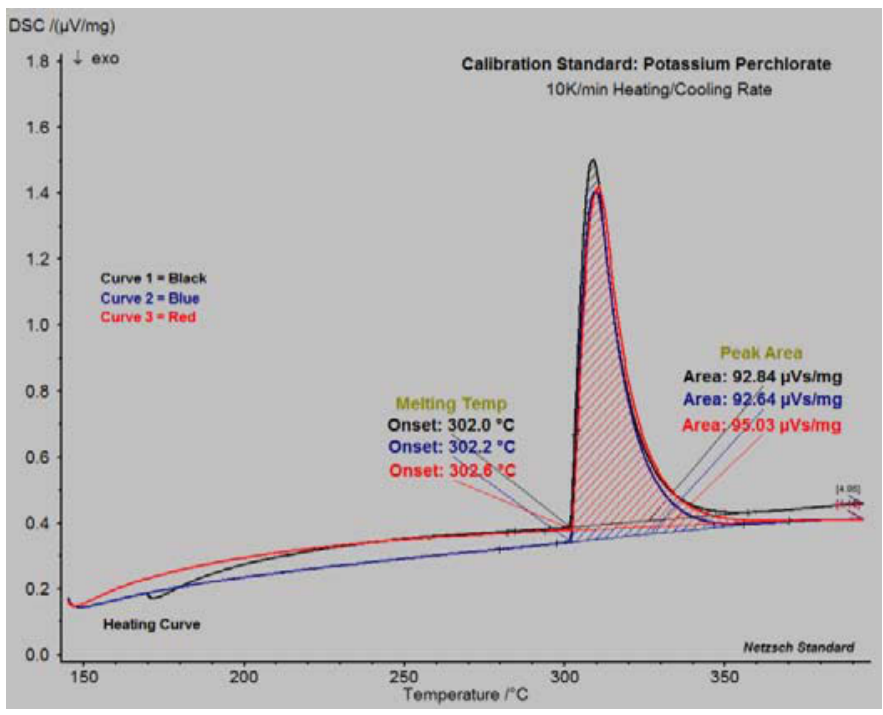

Figure B-5. $10 \mathrm{~K} / \mathrm{min}$ heating rate for the Potassium Perchlorate standard.

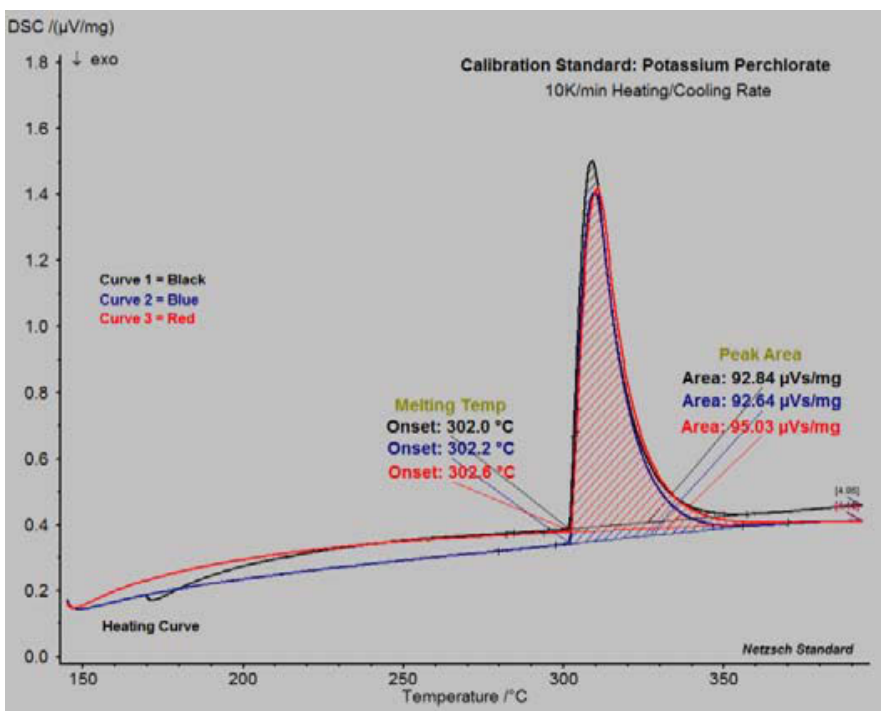

Figure B-6. $2 \mathrm{~K} / \mathrm{min}$ heating rate for the Potassium Perchlorate standard.

Table B-3. Onset and Peak values obtained from thermograms in Figure B-5 and B-6.

\begin{tabular}{|c|c|c|c|c|c|}
\hline \multicolumn{3}{|c|}{ Potassium Perchlorate Standard $\left(\mathrm{KClO}_{4}\right)$} \\
\hline \multicolumn{3}{|c|}{$10 \mathrm{~K} / \mathrm{min}$} \\
\hline $\begin{array}{c}\text { Onset Temp, } \\
{ }^{\circ} \mathrm{C}\end{array}$ & $\begin{array}{c}\text { Peak Area, } \\
\text { Vs/mg }\end{array}$ & & $\begin{array}{c}\text { Onset Temp, } \\
{ }^{\circ} \mathrm{C}\end{array}$ & $\begin{array}{c}\text { Peak Area, } \\
\mu \mathrm{Vs} / \mathrm{mg}\end{array}$ \\
\hline 1 & 302.0 & 92.84 & 1 & 299.8 & 97.51 \\
\hline 2 & 302.2 & 92.64 & 2 & 300.0 & 97.22 \\
\hline 3 & 302.6 & 95.03 & 3 & 299.8 & 97.4 \\
\hline Avg & 302.3 & 93.5 & Avg & 299.9 & 97.4 \\
\hline
\end{tabular}




\section{B4. Cesium Chloride Standard}

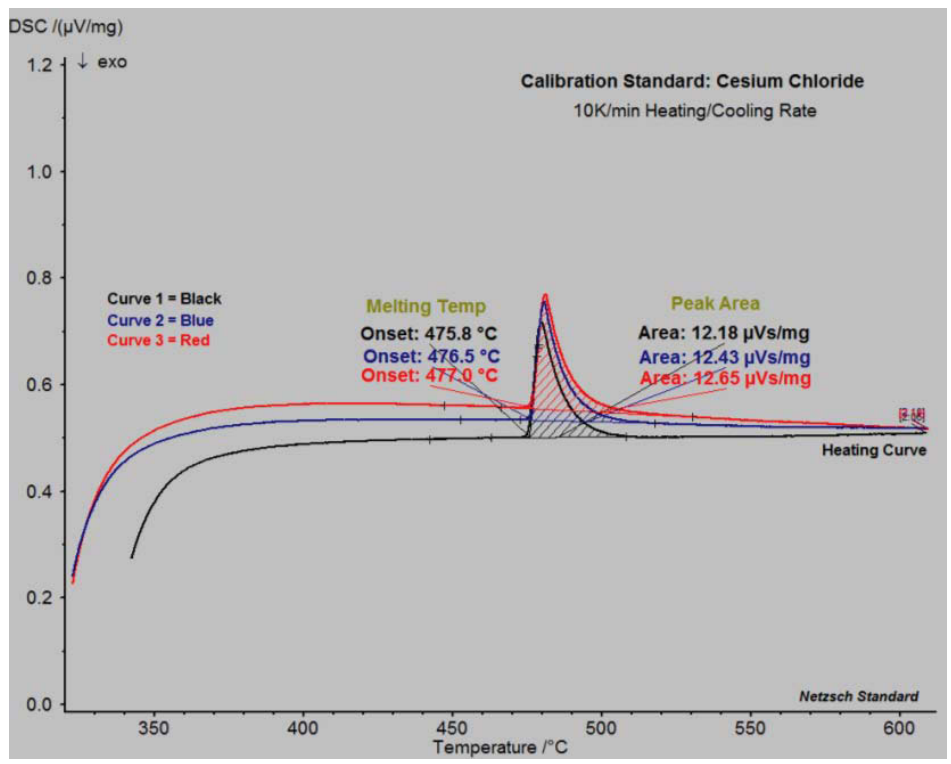

Figure B-7. $10 \mathrm{~K} / \mathrm{min}$ heating rate for the Cesium Chloride standard.

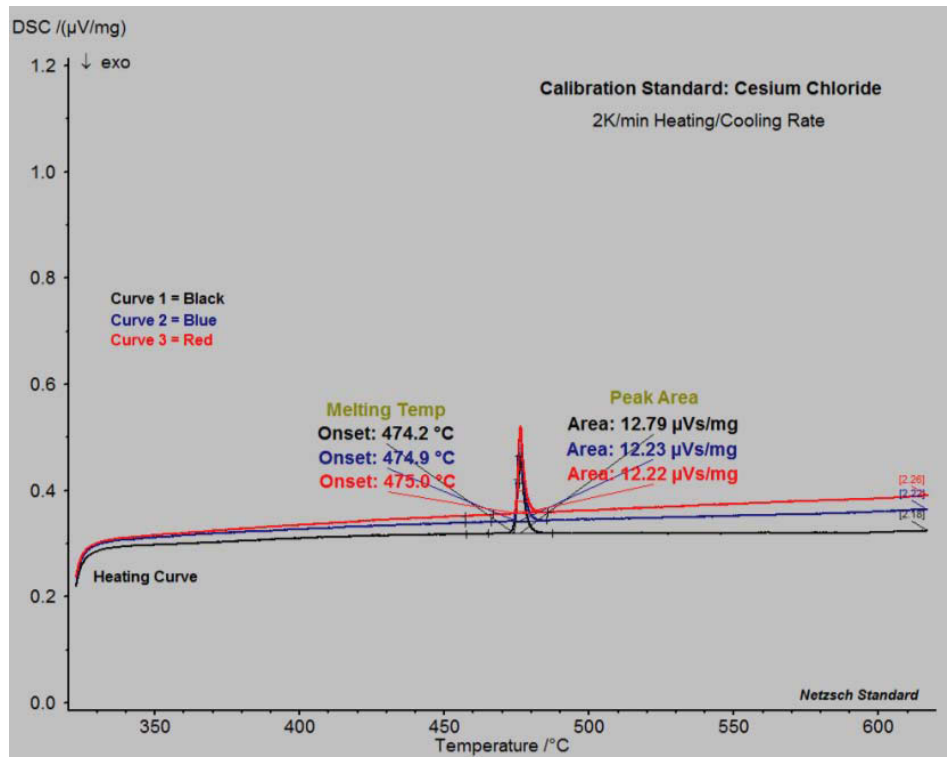

Figure B-8. $2 \mathrm{~K} / \mathrm{min}$ heating rate for the Cesium Chloride standard.

Table B-4. Onset and Peak values obtained from thermograms in Figure B-7 and B-8.

\begin{tabular}{|c|c|c|c|c|c|}
\hline \multicolumn{2}{|c|}{ Cesium Chloride Standard (CsCl) } \\
\hline & $\begin{array}{c}\text { Onset Temp, } \\
{ }^{\circ} \mathrm{C}\end{array}$ & $\begin{array}{c}\text { Peak Area, } \\
\mu \mathrm{Vs} / \mathrm{mg}\end{array}$ & & $\begin{array}{c}\text { Onset Temp, } \\
{ }^{\circ} \mathrm{C}\end{array}$ & $\begin{array}{c}\text { Peak Area, } \\
\mu \mathrm{Vs} / \mathrm{mg}\end{array}$ \\
\hline 1 & 475.8 & 12.18 & 1 & 474.2 & 12.79 \\
\hline 2 & 476.5 & 12.43 & 2 & 474.9 & 12.23 \\
\hline 3 & 477.0 & 12.65 & 3 & 475.0 & 12.22 \\
\hline Avg & 476.4 & 12.4 & $\mathrm{Avg}$ & 474.7 & 12.4 \\
\hline
\end{tabular}




\section{B5. Potassium Chromate}

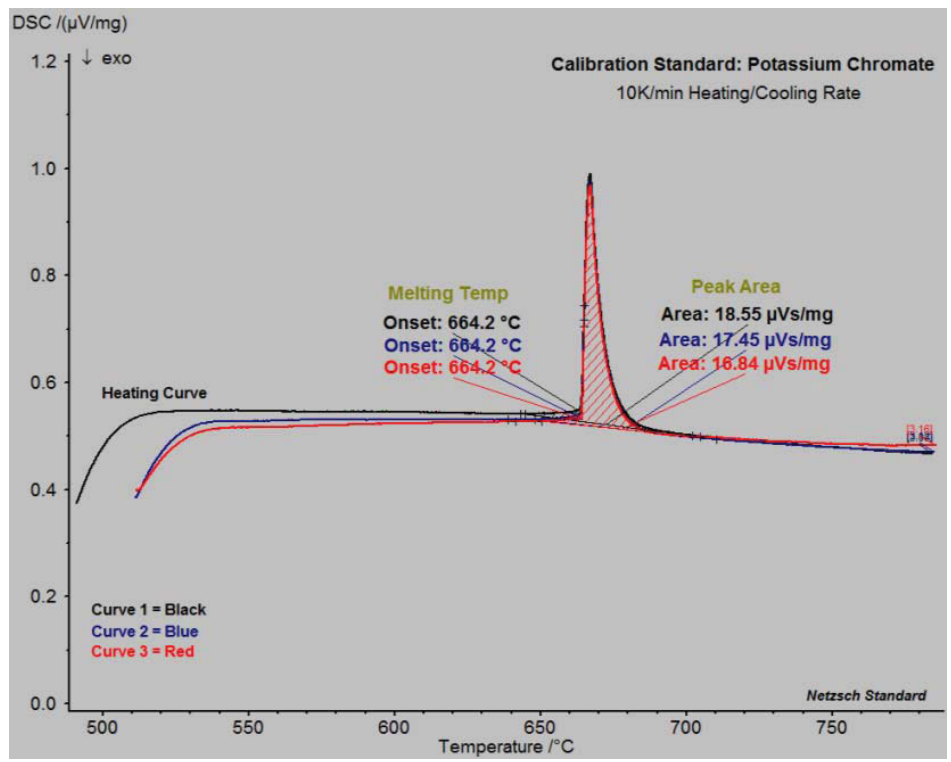

Figure B-9. $10 \mathrm{~K} / \mathrm{min}$ heating rate for the Potassium Chromate standard.

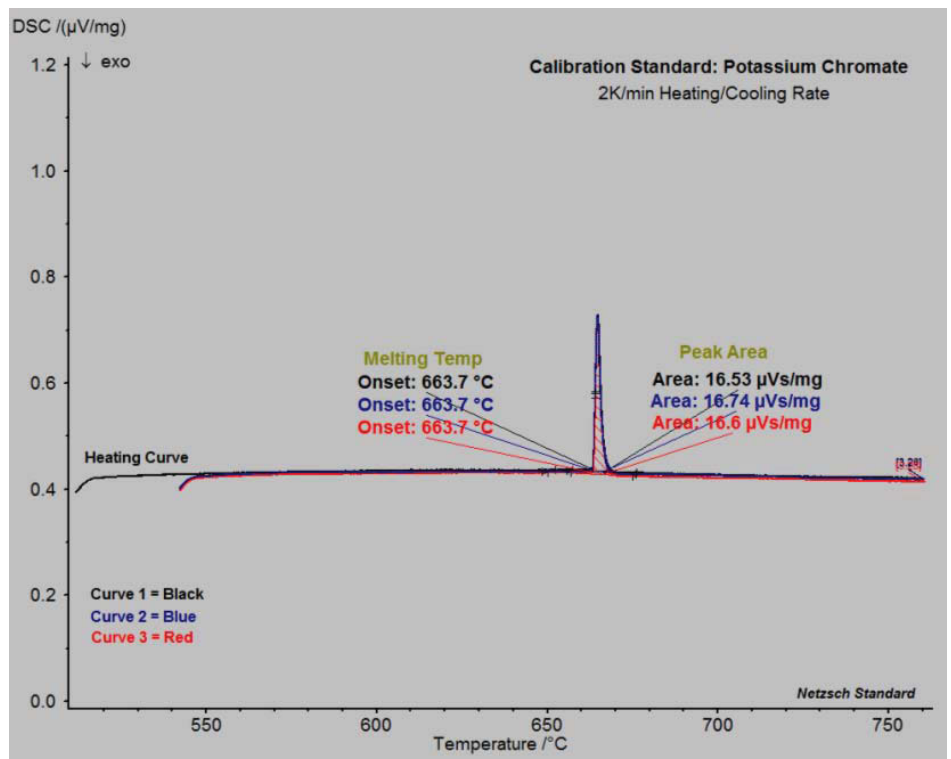

Figure B-10. $2 \mathrm{~K} / \mathrm{min}$ heating rate for the potassium Chromate standard.

Table B-5. Onset and Peak values obtained from thermograms in Figure B-9 and B-10.

\begin{tabular}{|c|c|c|c|c|c|}
\hline \multicolumn{6}{|c|}{ Potassium Chromate Standard } \\
\hline \multicolumn{3}{|c|}{$10 \mathrm{~K} / \mathrm{min}$} & \multicolumn{3}{|c|}{$2 \mathrm{~K} / \mathrm{min}$} \\
\hline & $\begin{array}{c}\text { Onset Temp, } \\
{ }^{\circ} \mathrm{C}\end{array}$ & $\begin{array}{c}\text { Peak Area, } \\
\mu V_{s} / m g\end{array}$ & & $\begin{array}{c}\text { Onset Temp, } \\
{ }^{\circ} \mathrm{C}\end{array}$ & $\begin{array}{c}\text { Peak Area, } \\
\mu V_{s} / m g\end{array}$ \\
\hline 1 & 664.2 & 18.55 & 1 & 667.3 & 16.53 \\
\hline 2 & 664.2 & 17.45 & 2 & 667.3 & 16.74 \\
\hline 3 & 664.2 & 16.84 & 3 & 667.3 & 16.6 \\
\hline Avg & 664.2 & 17.6 & Avg & 667.3 & 16.6 \\
\hline
\end{tabular}




\section{Appendix C}

\section{Study of LiCl-KCl}




\section{C1. $2 \mathrm{~K} / \mathrm{min}$ Heating Rate}

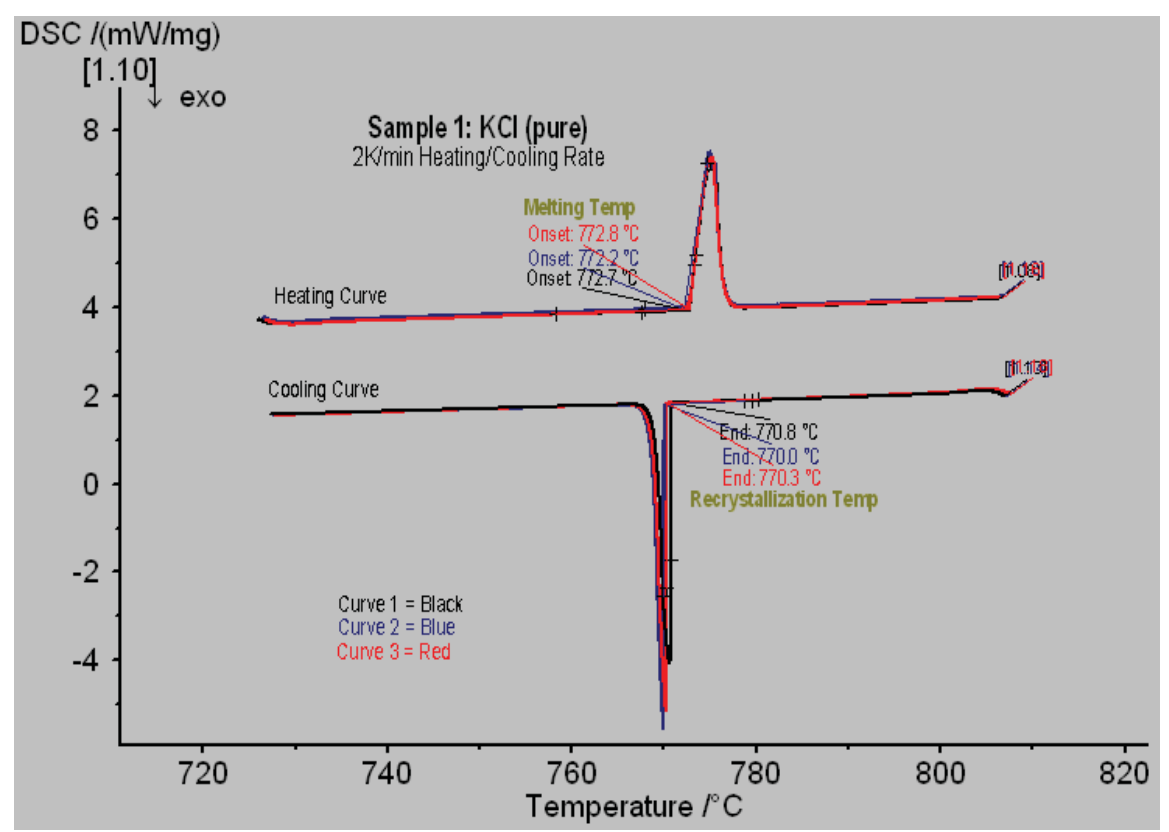

Figure C-1. DSC curve for $\mathrm{LiCl}-\mathrm{KCl}$ sample $1(0 \mathrm{wt} \% \mathrm{LiCl})$ with $2 \mathrm{~K} / \mathrm{min}$ heating rate.

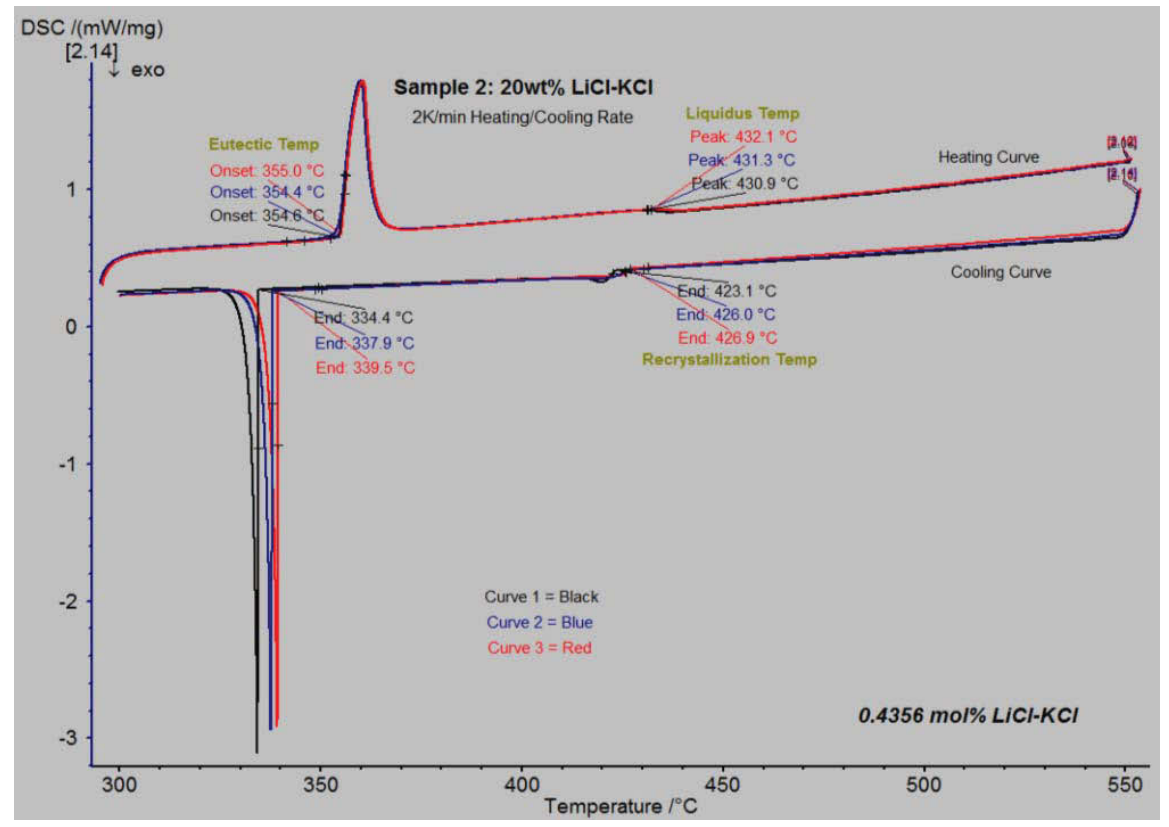

Figure C-2. DSC curve for $\mathrm{LiCl}-\mathrm{KCl}$ sample $2(20 \mathrm{wt} \% \mathrm{LiCl})$ with $2 \mathrm{~K} / \mathrm{min}$ heating rate. 


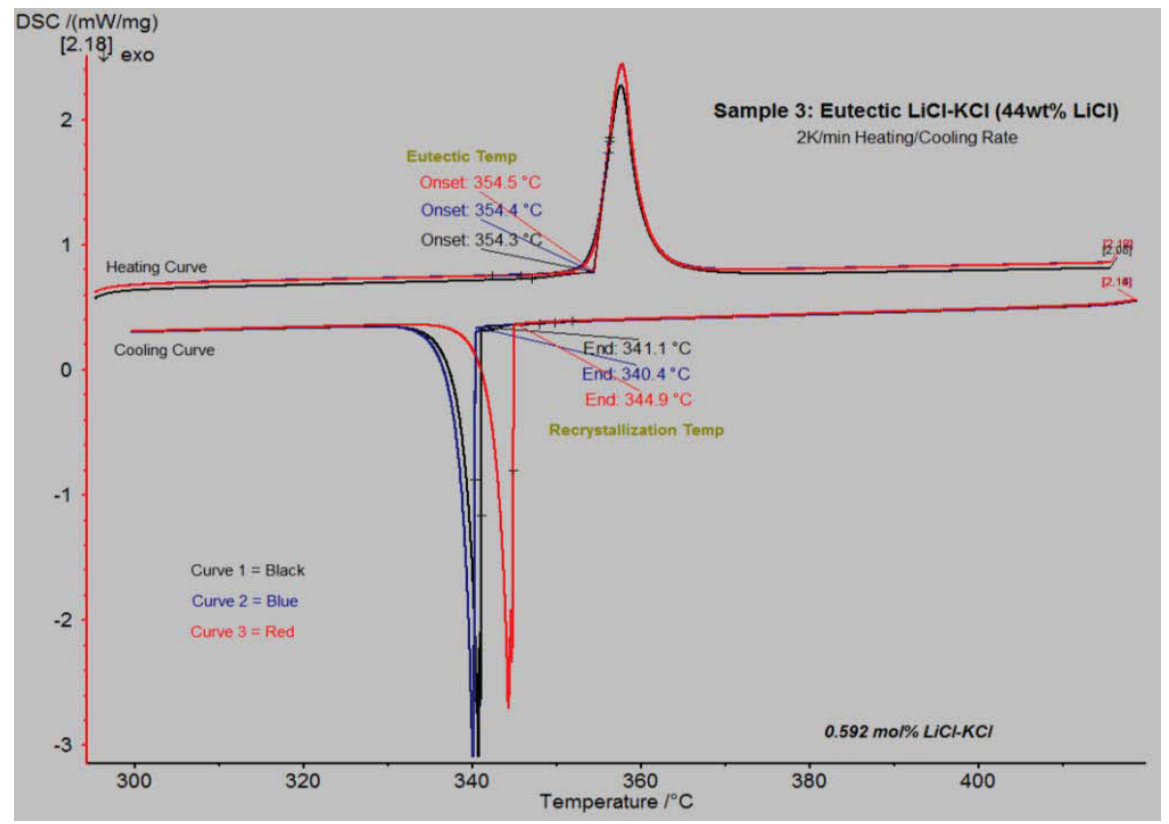

Figure C-3. DSC curve for LiCl-KCl sample 3 (44 wt $\% \mathrm{LiCl}$ ) with $2 \mathrm{~K} / \mathrm{min}$ heating rate.

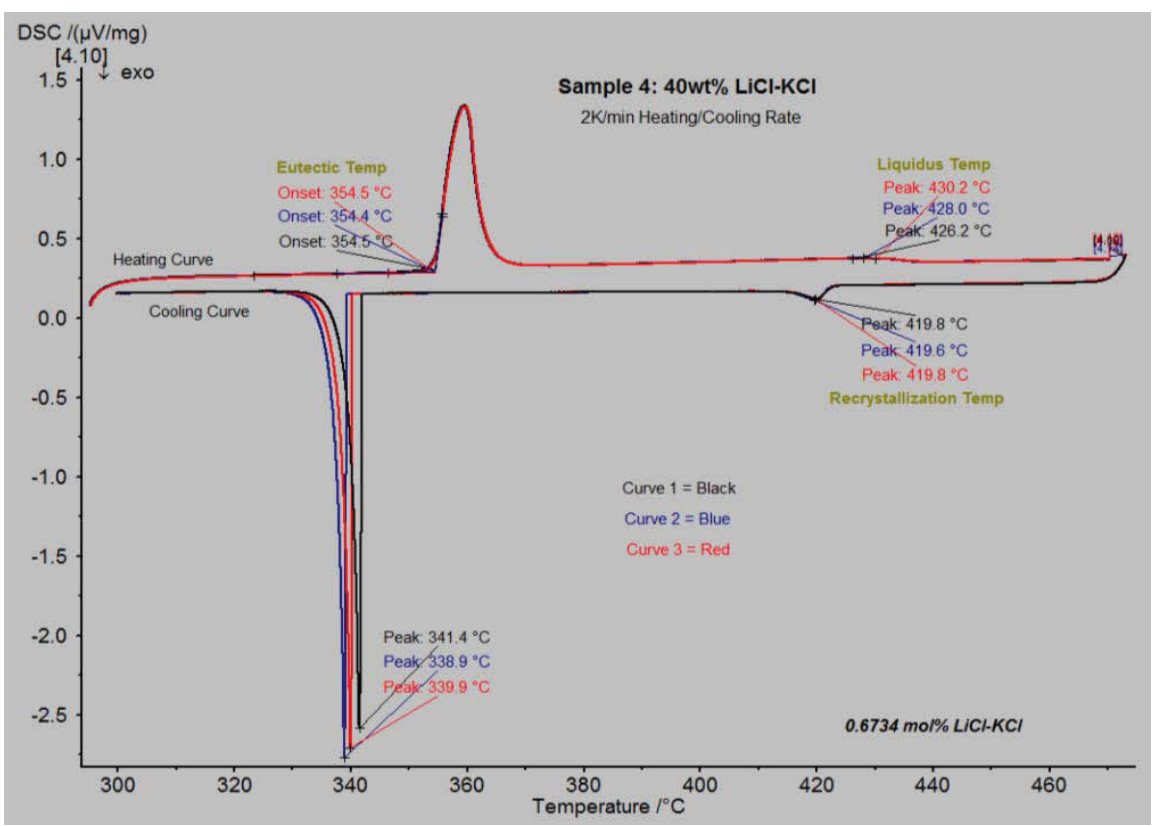

Figure C-4. DSC curve for $\mathrm{LiCl}-\mathrm{KCl}$ sample $4(40 \mathrm{wt} \% \mathrm{LiCl})$ with $2 \mathrm{~K} / \mathrm{min}$ heating rate. 


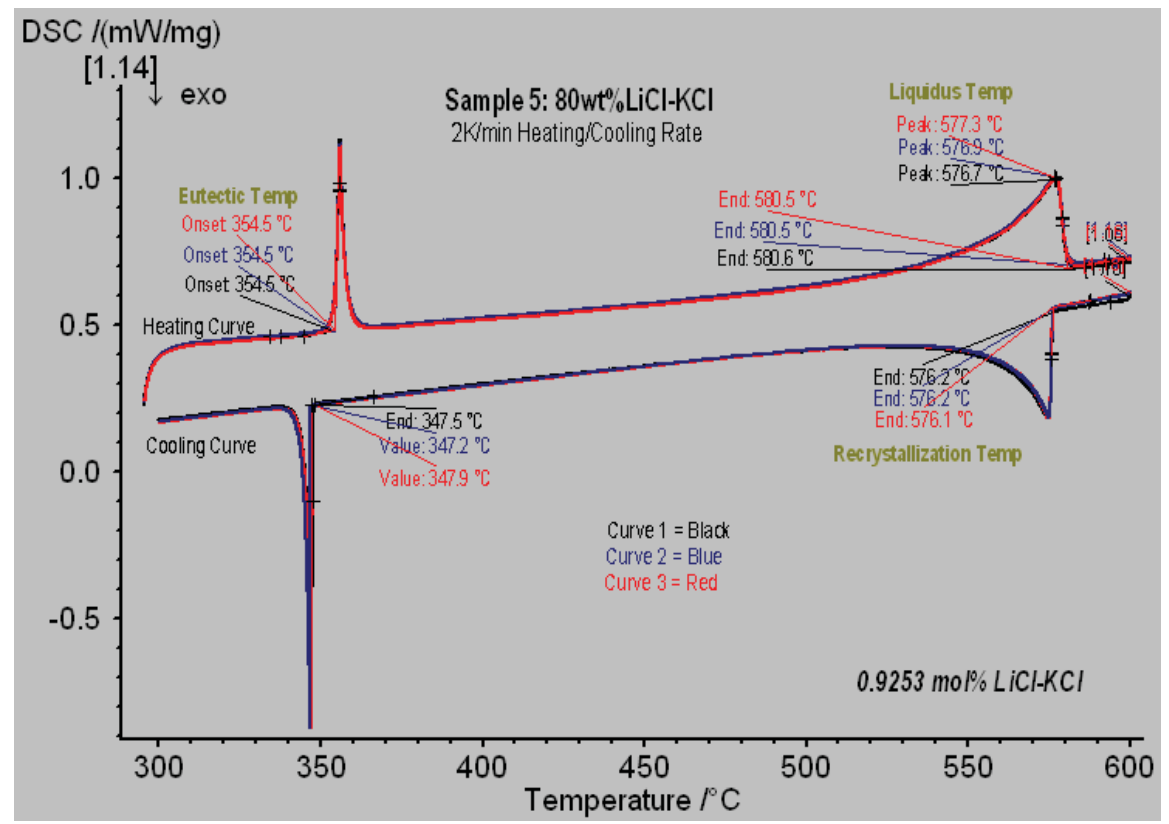

Figure C-5. DSC curve for $\mathrm{LiCl}-\mathrm{KCl}$ sample $5(80 \mathrm{wt} \% \mathrm{LiCl})$ with $2 \mathrm{~K} / \mathrm{min}$ heating rate.

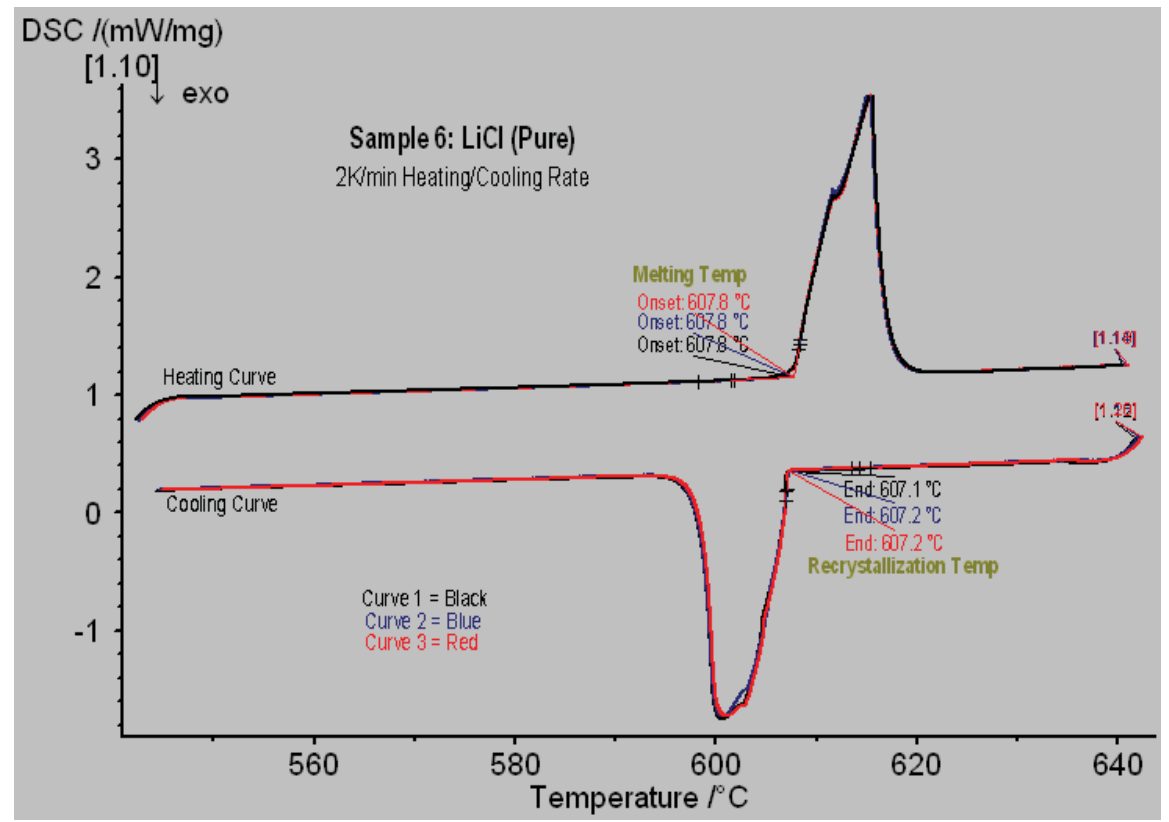

Figure C-6. DSC curve for $\mathrm{LiCl}-\mathrm{KCl}$ sample $6(100 \mathrm{wt} \% \mathrm{LiCl})$ with $2 \mathrm{~K} / \mathrm{min}$ heating rate. 


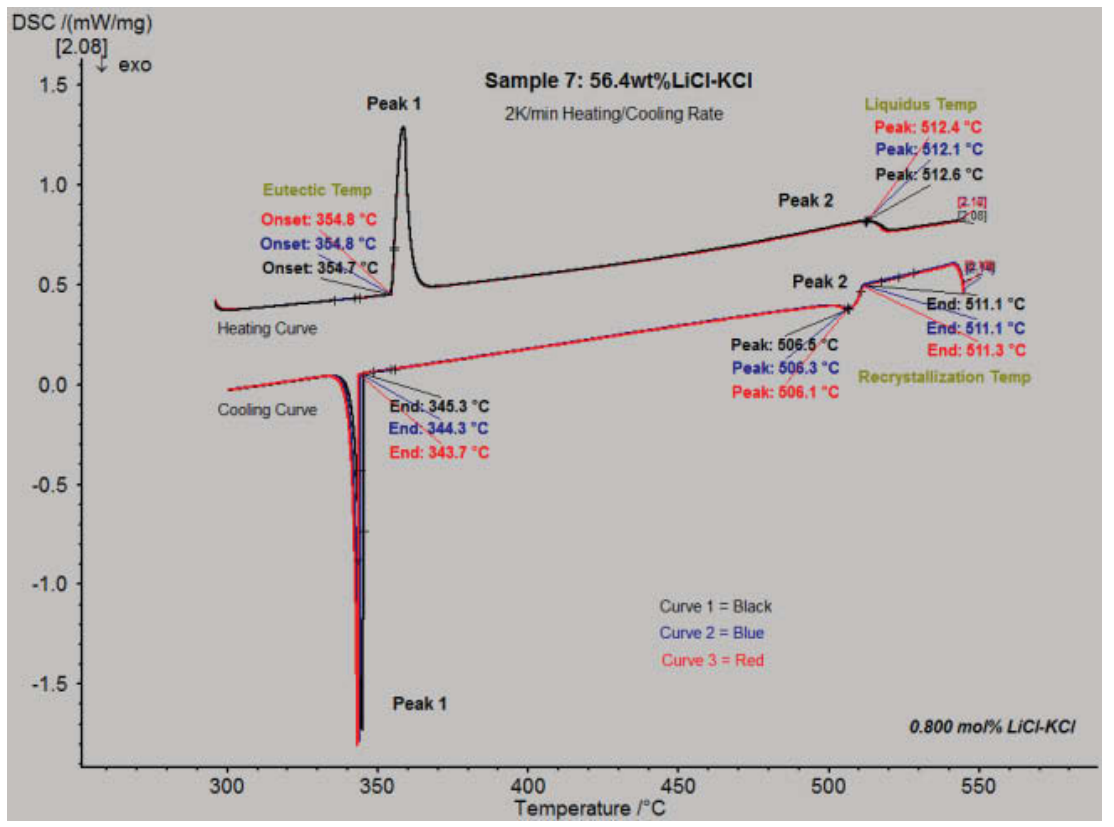

Figure C-7. DSC curve for LiCl-KCl sample 7 (56.4 wt\% LiCl) with $2 \mathrm{~K} / \mathrm{min}$ heating rate.

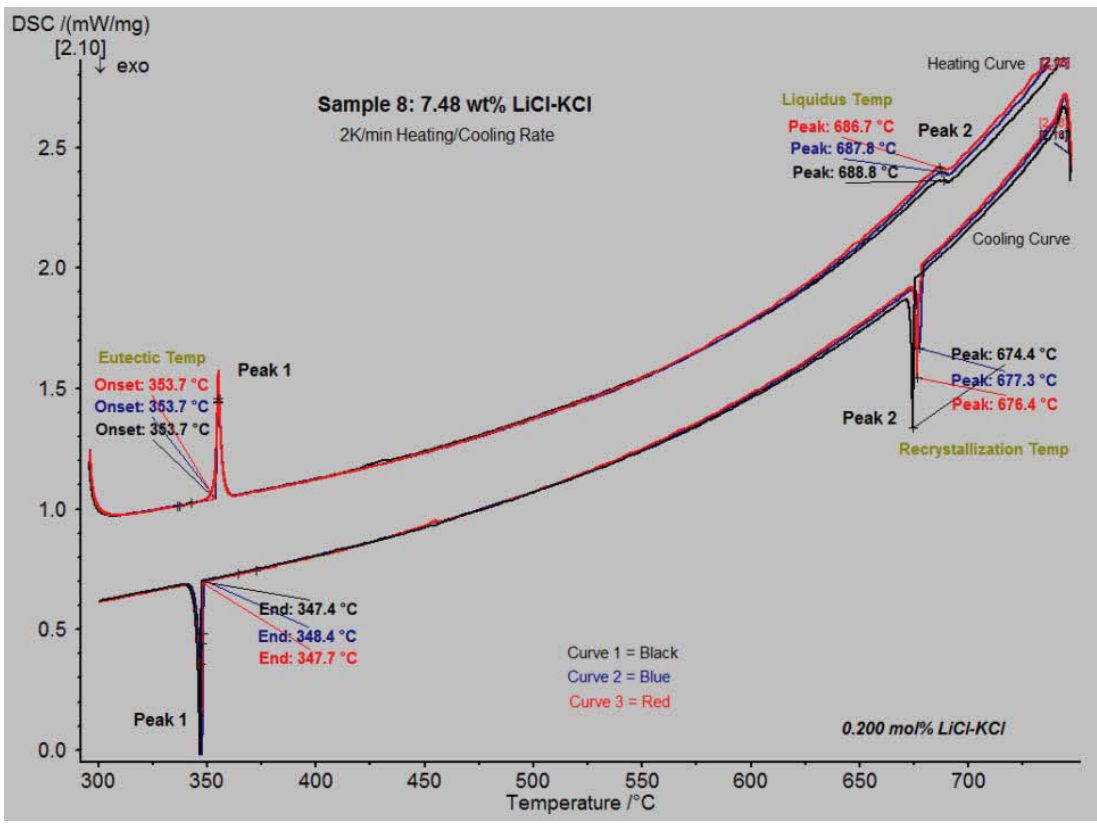

Figure C-8. DSC curve for $\mathrm{LiCl}-\mathrm{KCl}$ sample $8(7.5 \mathrm{wt} \% \mathrm{LiCl})$ with $2 \mathrm{~K} / \mathrm{min}$ heating rate. 
Table $\mathrm{C}-1$ provides information on the eutectic and liquidus temperatures for various compositions of $\mathrm{LiCl}-\mathrm{KCl}$ with a heating/cooling rate of $2 \mathrm{~K} / \mathrm{min}$.

Table C-1. Summary of results taken from Figure C-1 through Figure CB-8.

\begin{tabular}{|c|c|c|c|c|c|c|}
\hline & & & Curve 1 & Curve 2 & Curve 3 & Average \\
\hline \multirow{2}{*}{ Sample 1} & \multirow{2}{*}{$\mathrm{KCl}$ (pure) } & Eutectic Temp, ${ }^{\circ} \mathrm{C}$ & -- & -- & -- & -- \\
\hline & & Liquidus Temp, ${ }^{\circ} \mathrm{C}$ & 772.7 & 772.2 & 772.8 & 772.6 \\
\hline \multirow{2}{*}{ Sample 2} & \multirow{2}{*}{20 wt $\%$ LiCl-KCl } & Eutectic Temp, ${ }^{\circ} \mathrm{C}$ & 354.6 & 354.4 & 355.0 & 354.7 \\
\hline & & Liquidus Temp, ${ }^{\circ} \mathrm{C}$ & 430.9 & 431.3 & 432.1 & 431.4 \\
\hline \multirow{2}{*}{ Sample 3} & \multirow{2}{*}{44 wt\% LiCl-KCl } & Eutectic Temp, ${ }^{\circ} \mathrm{C}$ & 354.3 & 354.4 & 354.5 & 354.4 \\
\hline & & Liquidus Temp, ${ }^{\circ} \mathrm{C}$ & 354.3 & 354.4 & 354.5 & 354.4 \\
\hline \multirow{2}{*}{ Sample 4} & \multirow{2}{*}{$40 \mathrm{wt} \% \mathrm{LiCl}-\mathrm{KCl}$} & Eutectic Temp, ${ }^{\circ} \mathrm{C}$ & 354.5 & 354.4 & 354.5 & 354.5 \\
\hline & & Liquidus Temp, ${ }^{\circ} \mathrm{C}$ & 426.2 & 428.0 & 430.2 & 428.1 \\
\hline \multirow{2}{*}{ Sample 5} & \multirow{2}{*}{$80 \mathrm{wt} \% \mathrm{LiCl}-\mathrm{KCl}$} & Eutectic Temp, ${ }^{\circ} \mathrm{C}$ & 354.5 & 354.5 & 354.5 & 354.5 \\
\hline & & Liquidus Temp, ${ }^{\circ} \mathrm{C}$ & 576.7 & 576.9 & 577.3 & 577.0 \\
\hline \multirow{2}{*}{ Sample 6} & \multirow{2}{*}{$\mathrm{LiCl}$ (pure) } & Eutectic Temp, ${ }^{\circ} \mathrm{C}$ & -- & -- & -- & -- \\
\hline & & Liquidus Temp, ${ }^{\circ} \mathrm{C}$ & 607.8 & 607.8 & 607.8 & 607.8 \\
\hline \multirow{2}{*}{ Sample 7} & \multirow{2}{*}{$56.4 \mathrm{wt} \% \mathrm{LiCl}-\mathrm{KCl}$} & Eutectic Temp, ${ }^{\circ} \mathrm{C}$ & 354.7 & 354.8 & 354.8 & 354.8 \\
\hline & & Liquidus Temp, ${ }^{\circ} \mathrm{C}$ & 512.6 & 512.1 & 512.4 & 512.4 \\
\hline \multirow{2}{*}{ Sample 8} & \multirow{2}{*}{7.48 wt\% $\%$ LiCl-KCl } & Eutectic Temp, ${ }^{\circ} \mathrm{C}$ & 353.7 & 353.7 & 353.7 & 353.7 \\
\hline & & Liquidus Temp, ${ }^{\circ} \mathrm{C}$ & 688.8 & 687.8 & 686.7 & 687.8 \\
\hline
\end{tabular}




\section{C2. $10 \mathrm{~K} / \mathrm{min}$ Heating Rate}

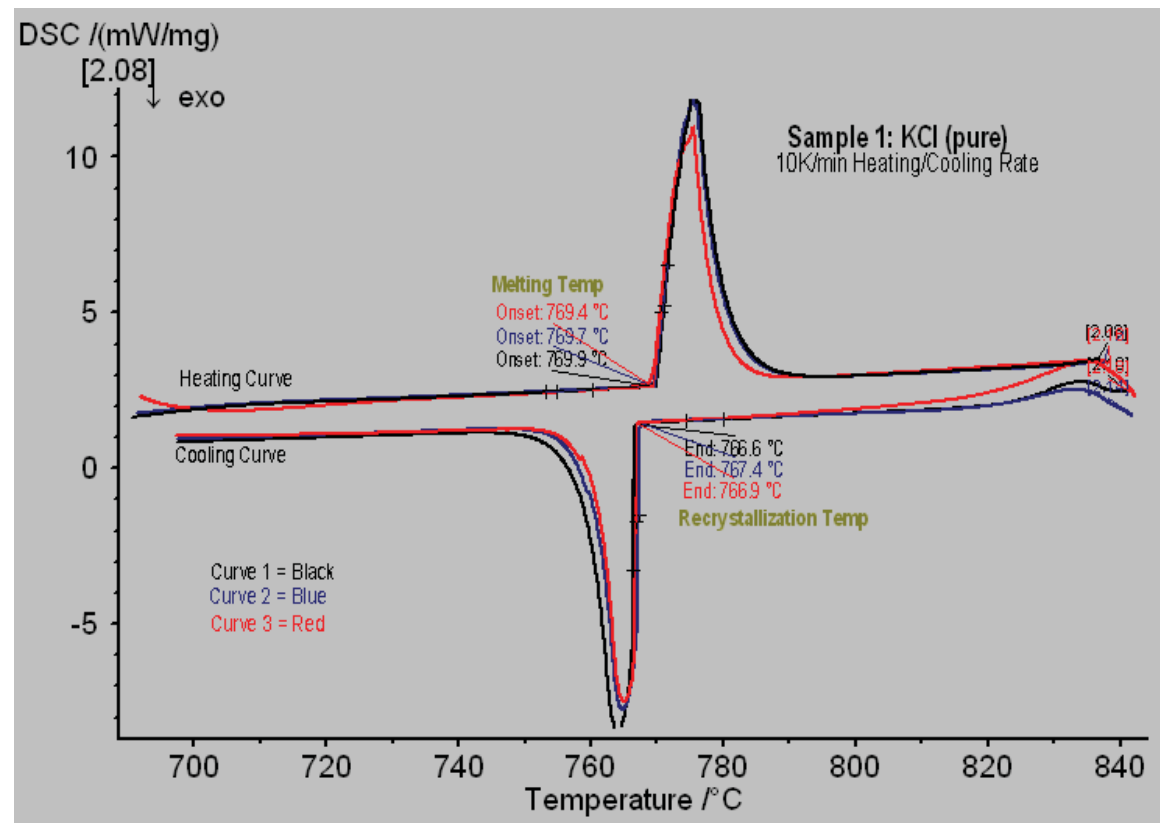

Figure C-9. DSC curve for $\mathrm{LiCl}-\mathrm{KCl}$ sample $1(0 \mathrm{wt} \% \mathrm{LiCl})$ with $10 \mathrm{~K} / \mathrm{min}$ heating rate.

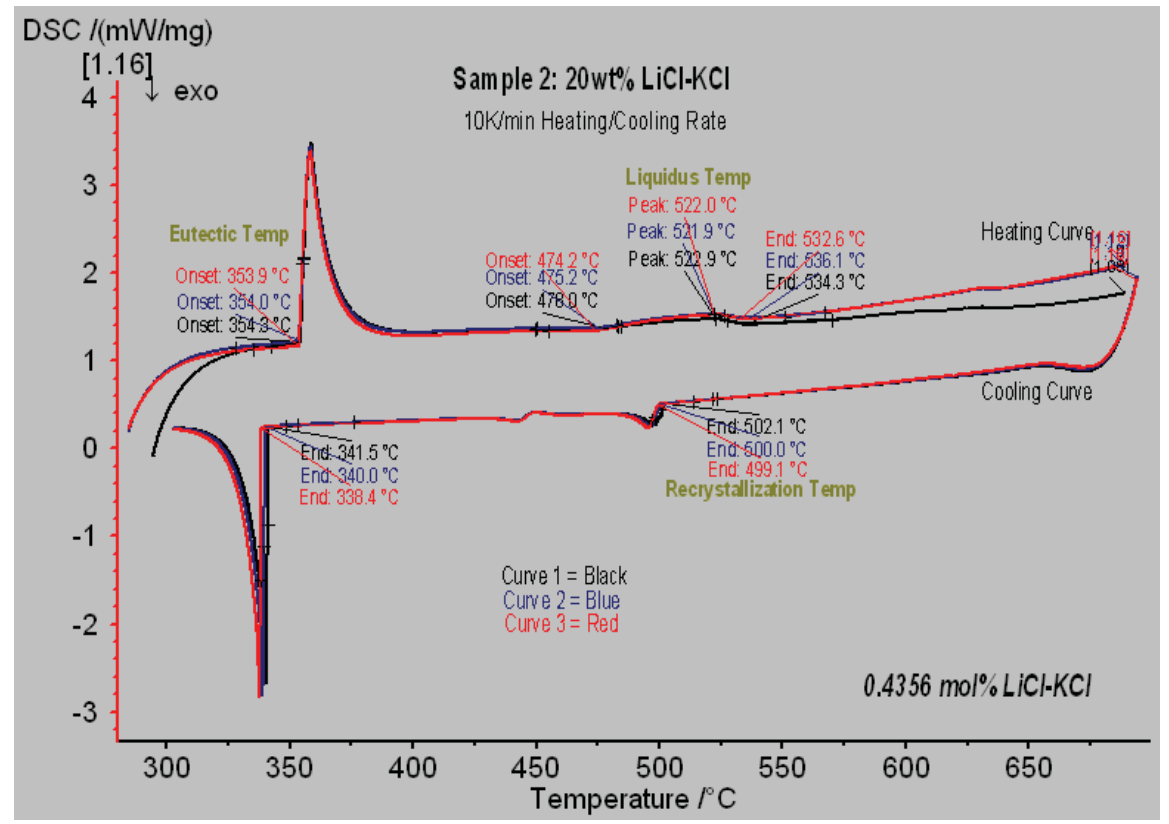

Figure C-10. DSC curve for LiCl-KCl sample $2(20 \mathrm{wt} \% \mathrm{LiCl})$ with $10 \mathrm{~K} / \mathrm{min}$ heating rate. 


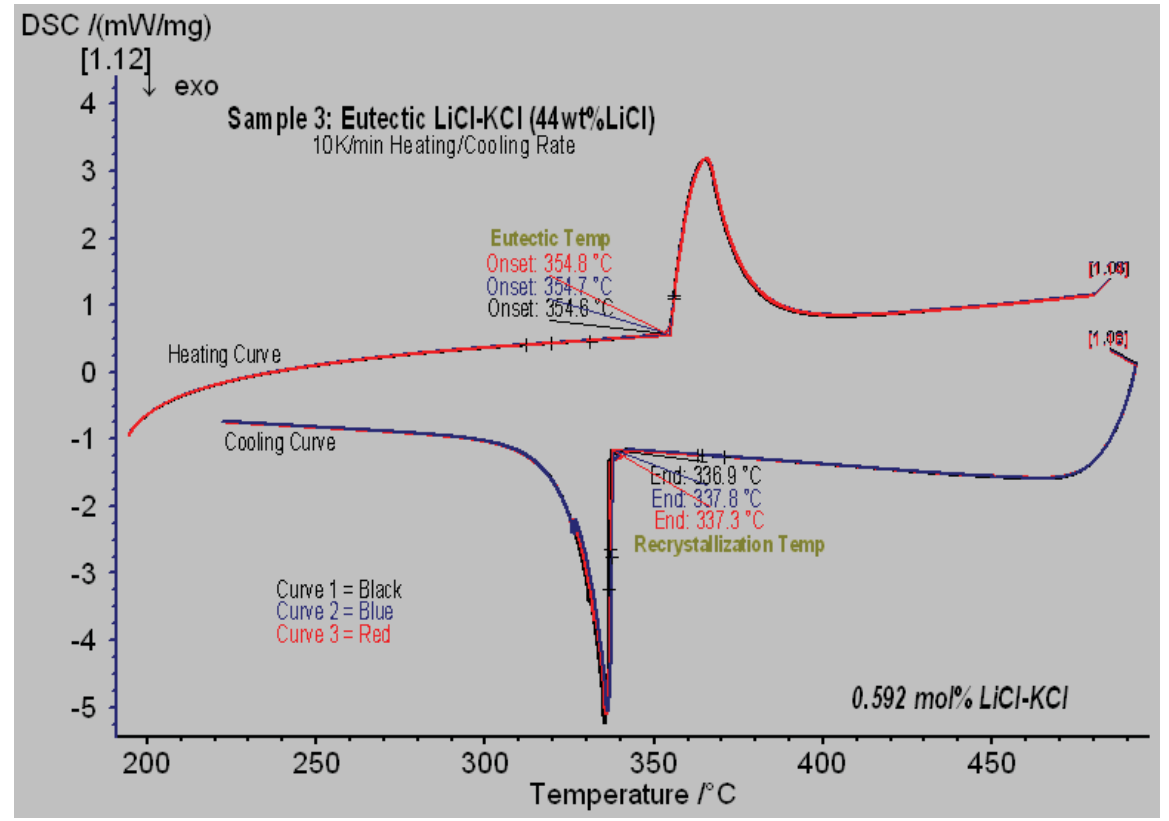

Figure C-11. DSC curve for LiCl-KCl sample 3 (44 wt $\% \mathrm{LiCl}$ ) with $10 \mathrm{~K} / \mathrm{min}$ heating rate.

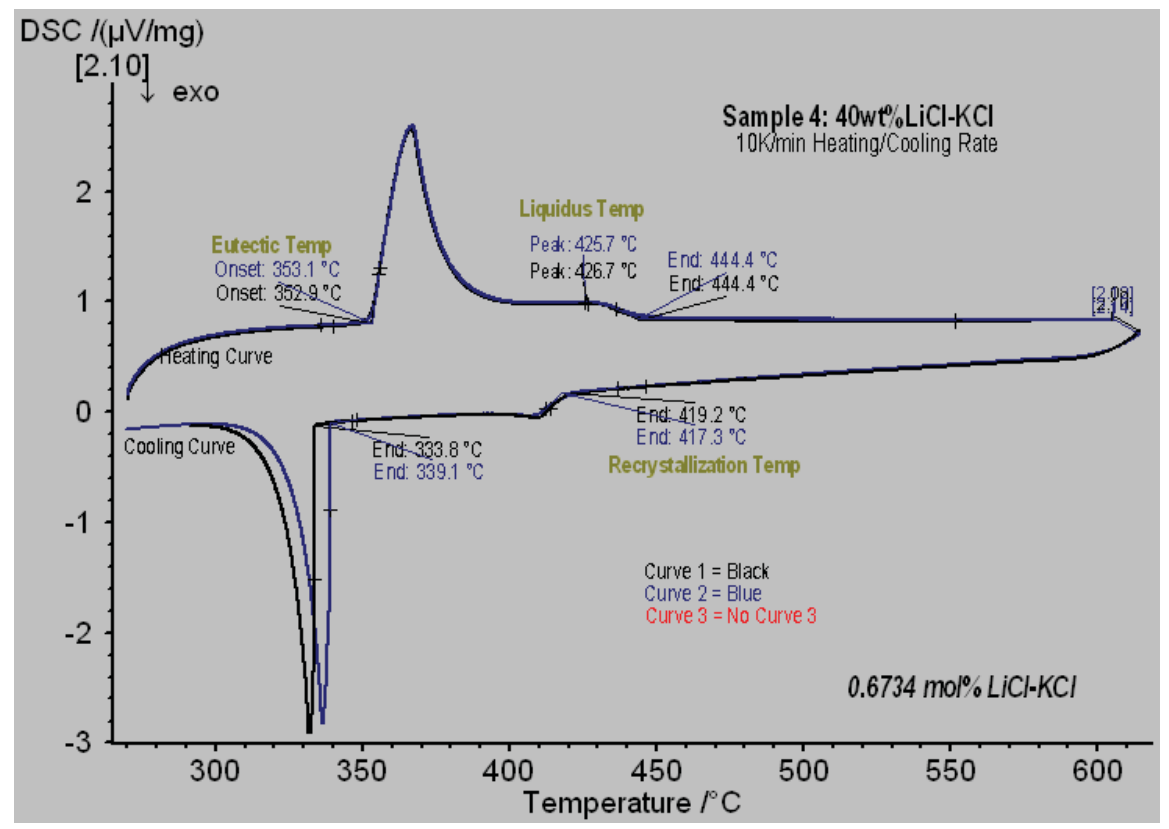

Figure C-12. DSC curve for LiCl-KCl sample 4 (40 wt $\% \mathrm{LiCl})$ with $10 \mathrm{~K} / \mathrm{min}$ heating rate. 


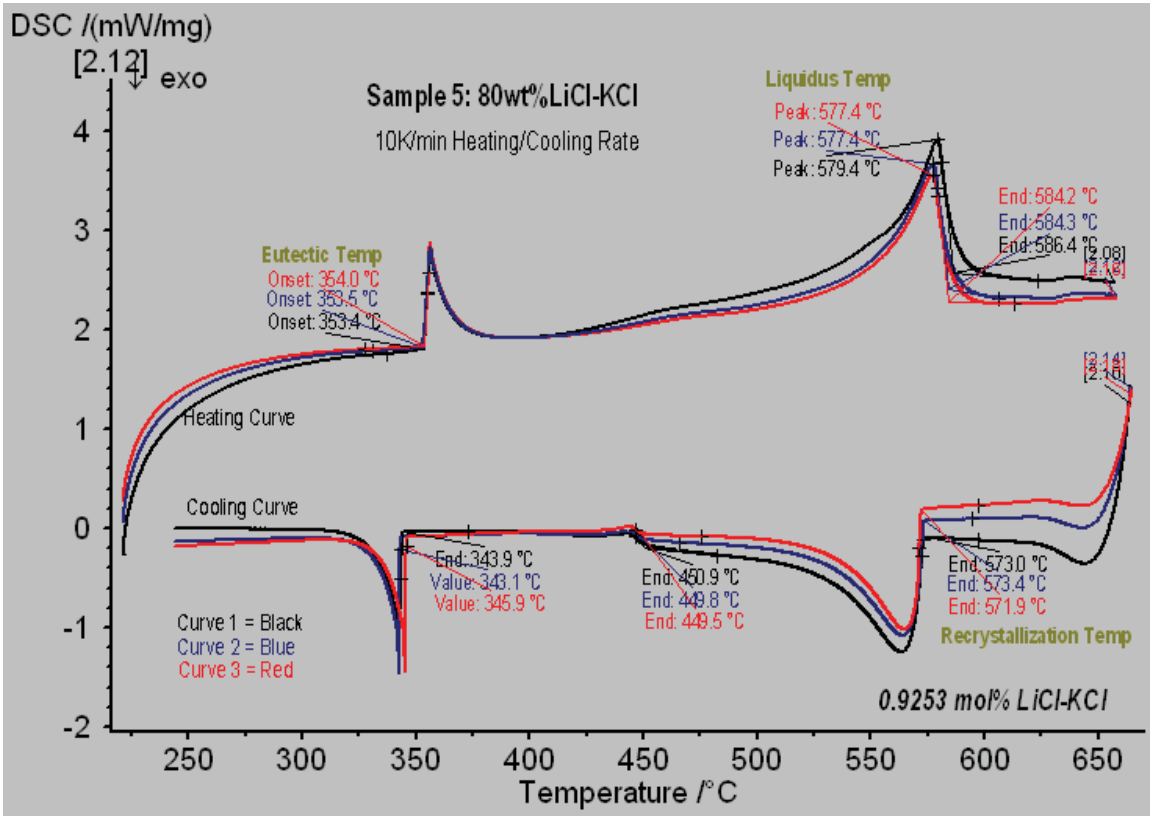

Figure C-13. DSC curve for LiCl-KCl sample $5(80 \mathrm{wt} \% \mathrm{LiCl})$ with $10 \mathrm{~K} / \mathrm{min}$ heating rate.

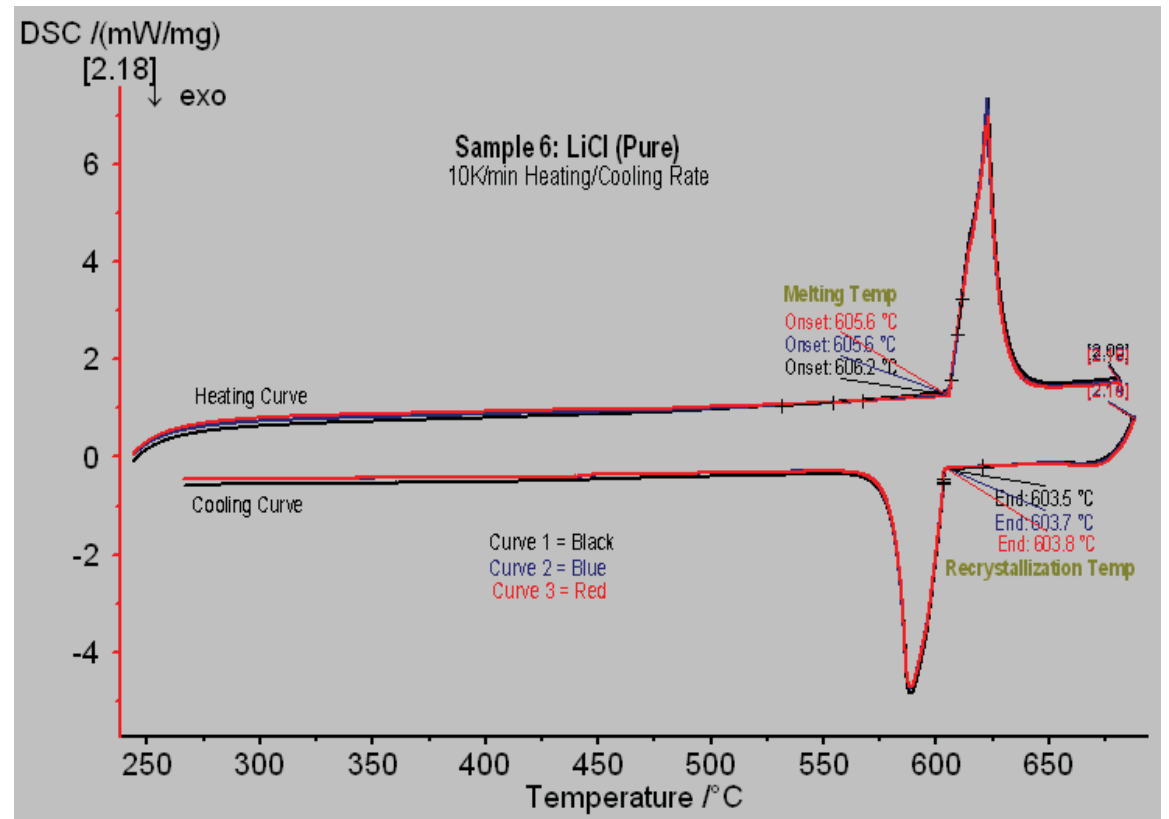

Figure C-14. DSC curve for LiCl-KCl sample $6(100 \mathrm{wt} \% \mathrm{LiCl})$ with $10 \mathrm{~K} / \mathrm{min}$ heating rate. 


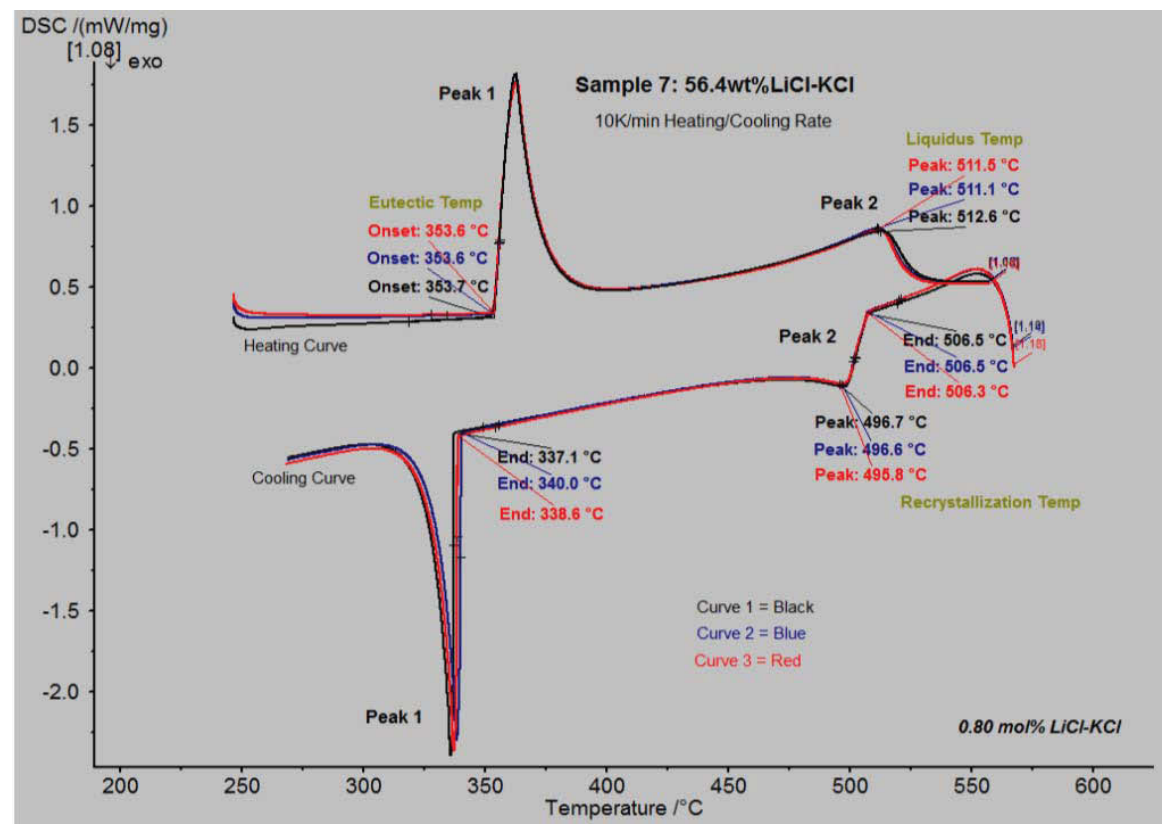

Figure C-15. DSC curve for LiCl-KCl sample 7 (56.4 wt $\% \mathrm{LiCl})$ with $10 \mathrm{~K} / \mathrm{min}$ heating rate.

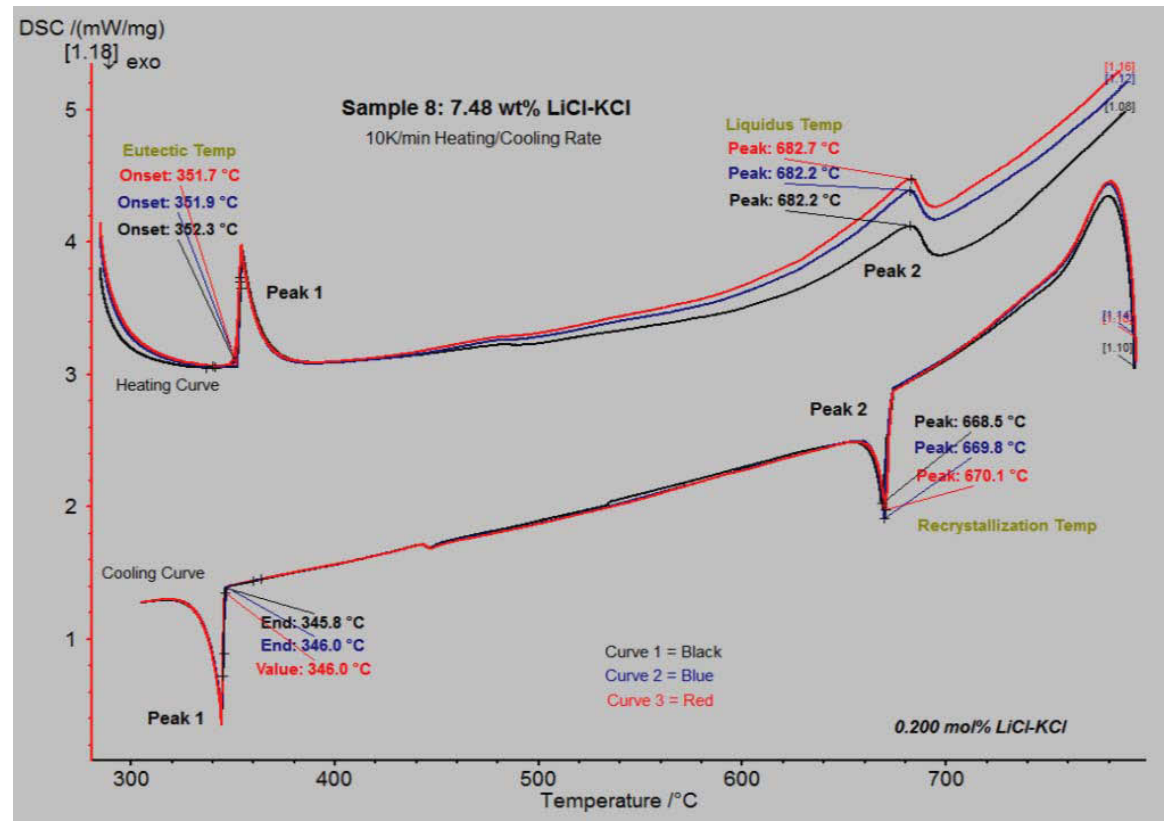

Figure $\mathrm{C}-16$. DSC curve for $\mathrm{LiCl}-\mathrm{KCl}$ sample $8(7.5 \mathrm{wt} \% \mathrm{LiCl})$ with $10 \mathrm{~K} / \mathrm{min}$ heating rate. 
Table B-2 provides information on the eutectic and liquidus temperatures for various compositions of LiCl-KCl with a heating/cooling rate of $10 \mathrm{~K} / \mathrm{min}$.

Table C-2. Summary of results taken from Figure C-9 through Figure C-16.

\begin{tabular}{|c|c|c|c|c|c|c|}
\hline \multicolumn{7}{|c|}{ Summary: $10 \mathrm{~K} / \mathrm{min}$ Heating Rate } \\
\hline & & & Curve 1 & Curve 2 & Curve 3 & Average \\
\hline \multirow{2}{*}{ Sample 1} & \multirow{2}{*}{$\mathrm{KCl}$ (pure) } & Eutectic Temp, ${ }^{\circ} \mathrm{C}$ & -- & -- & -- & -- \\
\hline & & Liquidus Temp, ${ }^{\circ} \mathrm{C}$ & 769.9 & 769.7 & 769.4 & 769.7 \\
\hline \multirow{2}{*}{ Sample 2} & \multirow{2}{*}{$20 \mathrm{wt} \% \mathrm{LiCl}-\mathrm{KCl}$} & Eutectic Temp, ${ }^{\circ} \mathrm{C}$ & 354.3 & 354.0 & 353.9 & 354.1 \\
\hline & & Liquidus Temp, ${ }^{\circ} \mathrm{C}$ & 522.9 & 521.9 & 522.0 & 522.3 \\
\hline \multirow{2}{*}{ Sample 3} & \multirow{2}{*}{$44 \mathrm{wt} \% \mathrm{LiCl}-\mathrm{KCl}$} & Eutectic Temp, ${ }^{\circ} \mathrm{C}$ & 354.6 & 354.7 & 354.8 & 354.7 \\
\hline & & Liquidus Temp, ${ }^{\circ} \mathrm{C}$ & 354.6 & 354.7 & 354.8 & 354.7 \\
\hline \multirow{2}{*}{ Sample 4} & \multirow{2}{*}{$40 \mathrm{wt} \% \mathrm{LiCl}-\mathrm{KCl}$} & Eutectic Temp, ${ }^{\circ} \mathrm{C}$ & 352.9 & 353.1 & NA & 353.0 \\
\hline & & Liquidus Temp, ${ }^{\circ} \mathrm{C}$ & 426.7 & 425.7 & NA & 326.2 \\
\hline \multirow{2}{*}{ Sample 5} & \multirow{2}{*}{$80 \mathrm{wt} \% \mathrm{LiCl}-\mathrm{KCl}$} & Eutectic Temp, ${ }^{\circ} \mathrm{C}$ & 353.4 & 353.5 & 354.0 & 353.6 \\
\hline & & Liquidus Temp, ${ }^{\circ} \mathrm{C}$ & 579.4 & 577.4 & 577.4 & 578.1 \\
\hline \multirow{2}{*}{ Sample 6} & \multirow{2}{*}{$\mathrm{LiCl}$ (pure) } & Eutectic Temp, ${ }^{\circ} \mathrm{C}$ & -- & -- & -- & -- \\
\hline & & Liquidus Temp, ${ }^{\circ} \mathrm{C}$ & 606.2 & 605.6 & 605.6 & 605.8 \\
\hline \multirow{2}{*}{ Sample 7} & \multirow{2}{*}{$56.4 \mathrm{wt} \% \mathrm{LiCl}-\mathrm{KCl}$} & Eutectic Temp, ${ }^{\circ} \mathrm{C}$ & 353.7 & 353.6 & 353.6 & 353.6 \\
\hline & & Liquidus Temp, ${ }^{\circ} \mathrm{C}$ & 512.6 & 511.1 & 511.5 & 511.7 \\
\hline \multirow{2}{*}{ Sample 8} & \multirow{2}{*}{$7.48 \mathrm{wt} \% \mathrm{LiCl}-\mathrm{KCl}$} & Eutectic Temp, ${ }^{\circ} \mathrm{C}$ & 352.3 & 351.9 & 351.7 & 352.0 \\
\hline & & Liquidus Temp, ${ }^{\circ} \mathrm{C}$ & 682.2 & 682.2 & 682.7 & 682.4 \\
\hline
\end{tabular}


Appendix D

\section{FFTF Fuel Processing}




\section{D1. Before FFTF Fuel Processing}

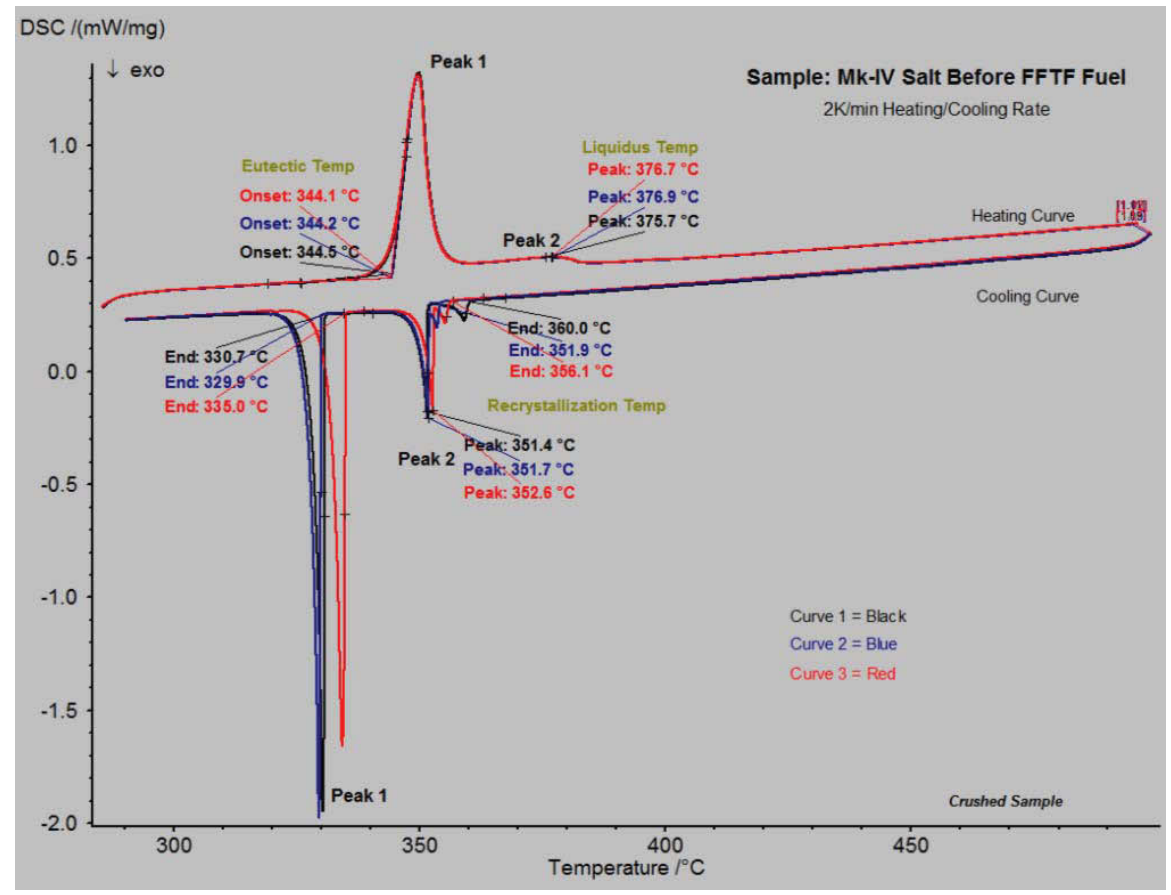

Figure D-1. DSC curve for before FFTF, $76.83 \mathrm{wt} \% \mathrm{LiCl}-\mathrm{KCl}$ with $2 \mathrm{~K} / \mathrm{min}$ heating rate.

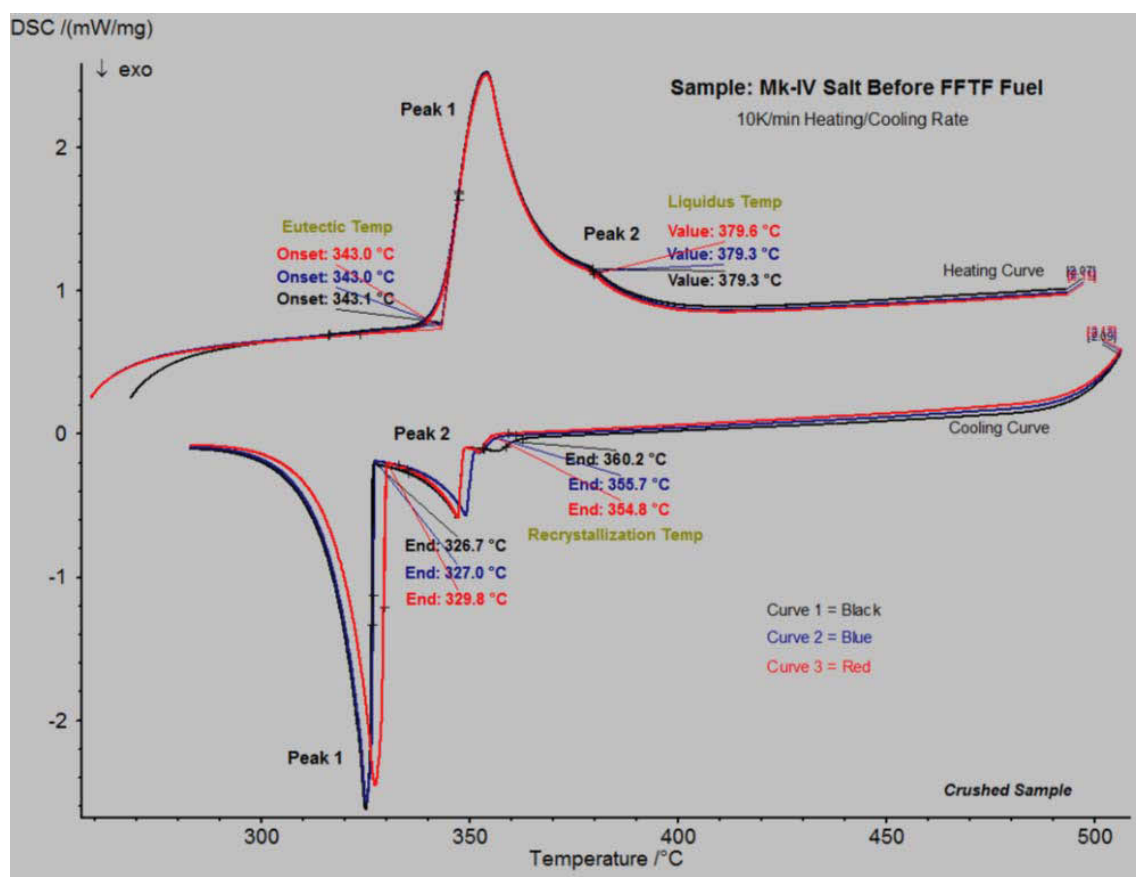

Figure D-2. DSC curve for before FFTF, $76.83 \mathrm{wt} \% \mathrm{LiCl}-\mathrm{KCl}$ with $10 \mathrm{~K} / \mathrm{min}$ heating rate. 


\section{D2. After FFTF Fuel Processing}

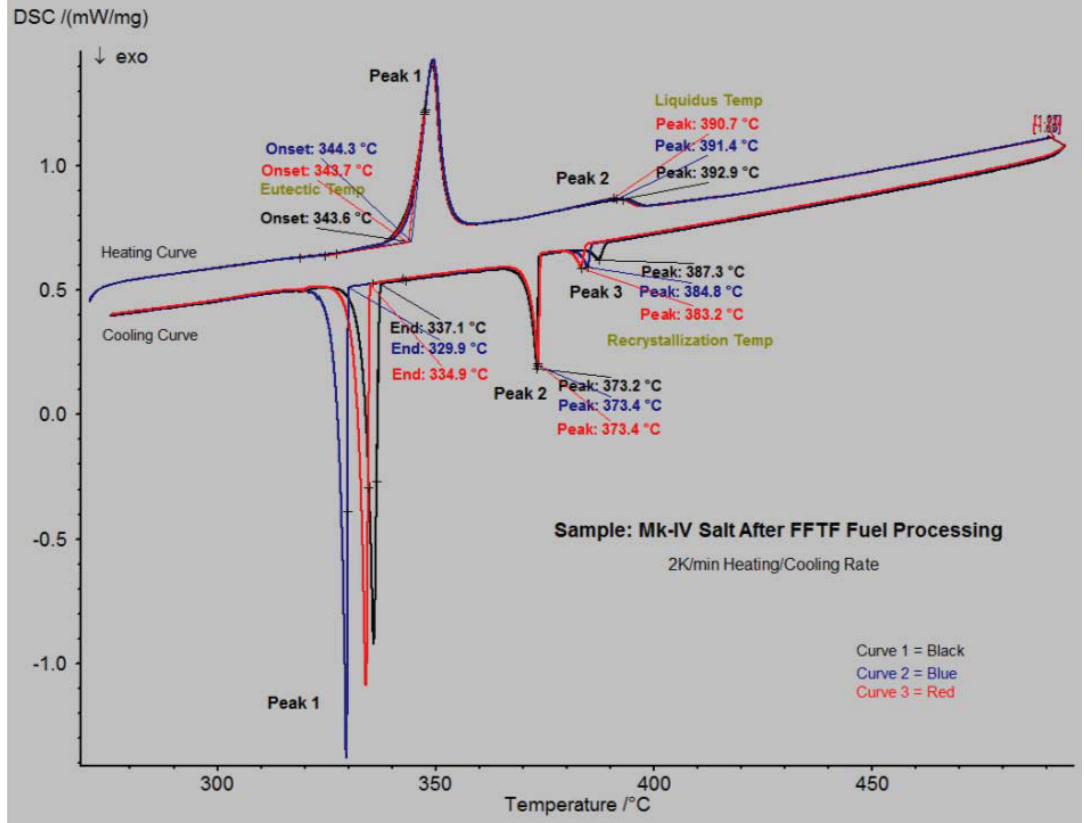

Figure D-3. DSC curve for after FFTF, $70.39 \mathrm{wt} \% \mathrm{LiCl}-\mathrm{KCl}$ with $2 \mathrm{~K} / \mathrm{min}$ heating rate.

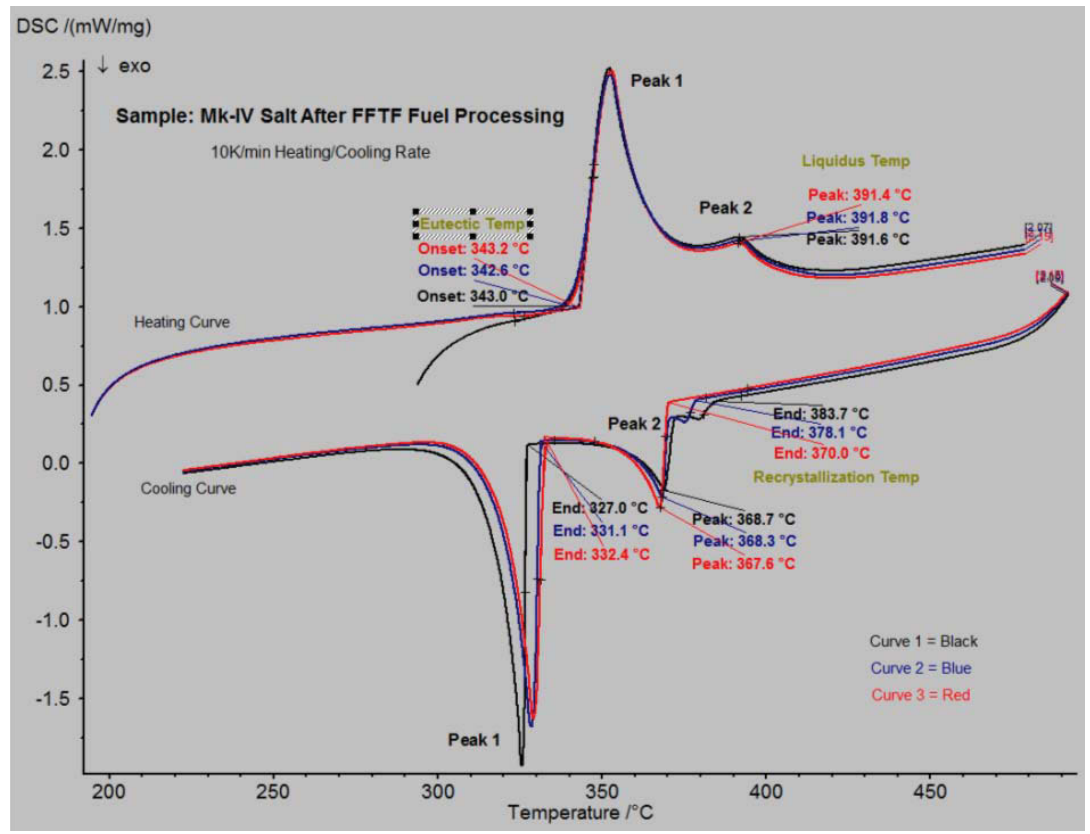

Figure D-4. DSC curve for after FFTF, $70.39 \mathrm{wt} \% \mathrm{LiCl}-\mathrm{KCl}$ with $10 \mathrm{~K} / \mathrm{min}$ heating rate. 


\section{D3. Comparison Before and After FFTF Fuel Processing}

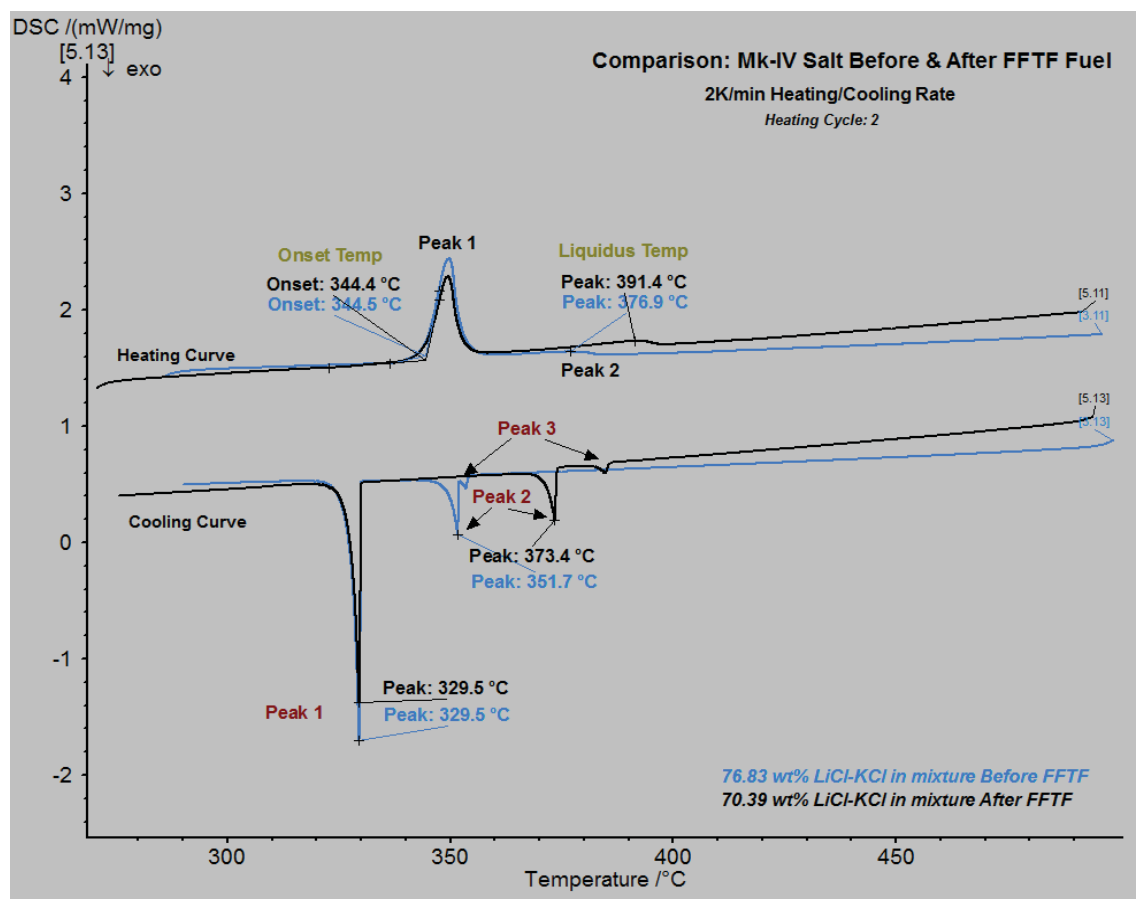

Figure D-5. DSC curves comparing before FFTF with After FFTF, $2 \mathrm{~K} / \mathrm{min}$ heating rate.

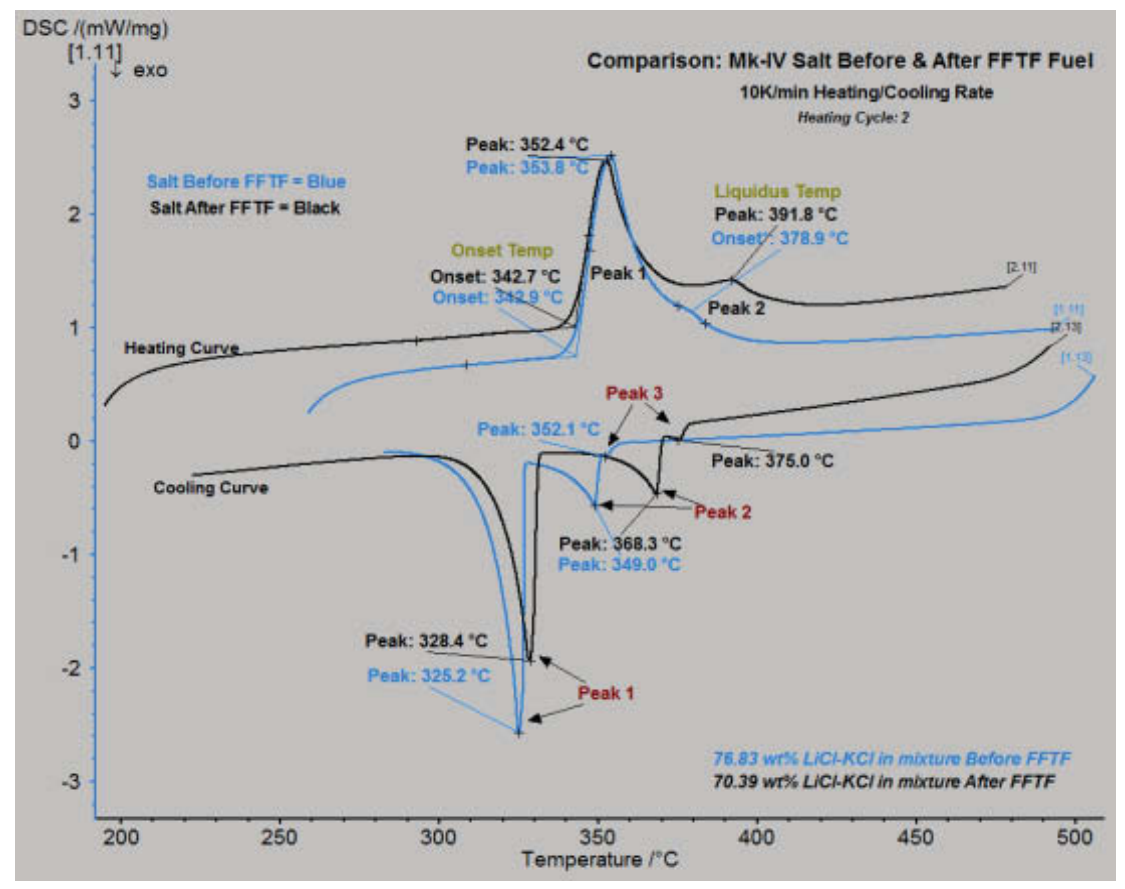

Figure D-6. DSC curves comparing before FFTF with After FFTF, $10 \mathrm{~K} / \mathrm{min}$ heating rate. 
Appendix E

INTEC Fuel Processing 


\section{E1. INTEC B25-1}

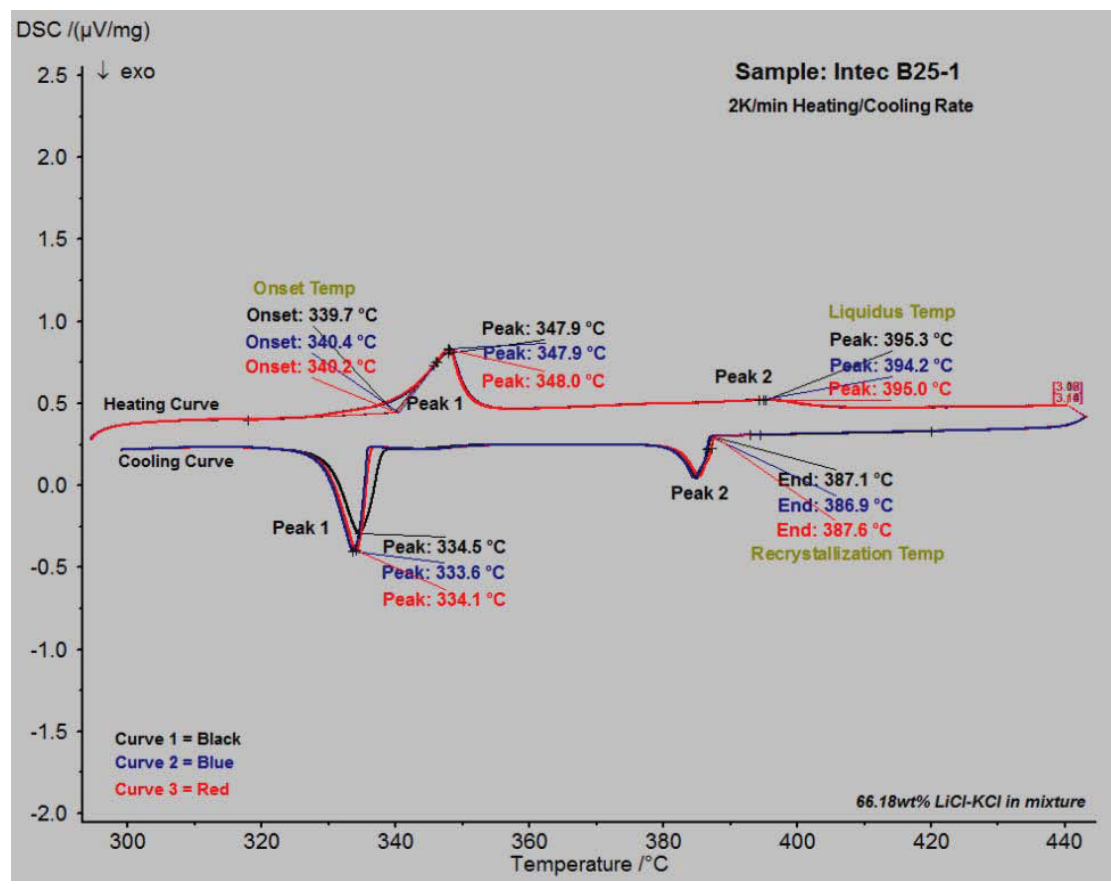

Figure E-1. DSC curves of sample, INTEC B25-1, $2 \mathrm{~K} / \mathrm{min}$ heating rate.

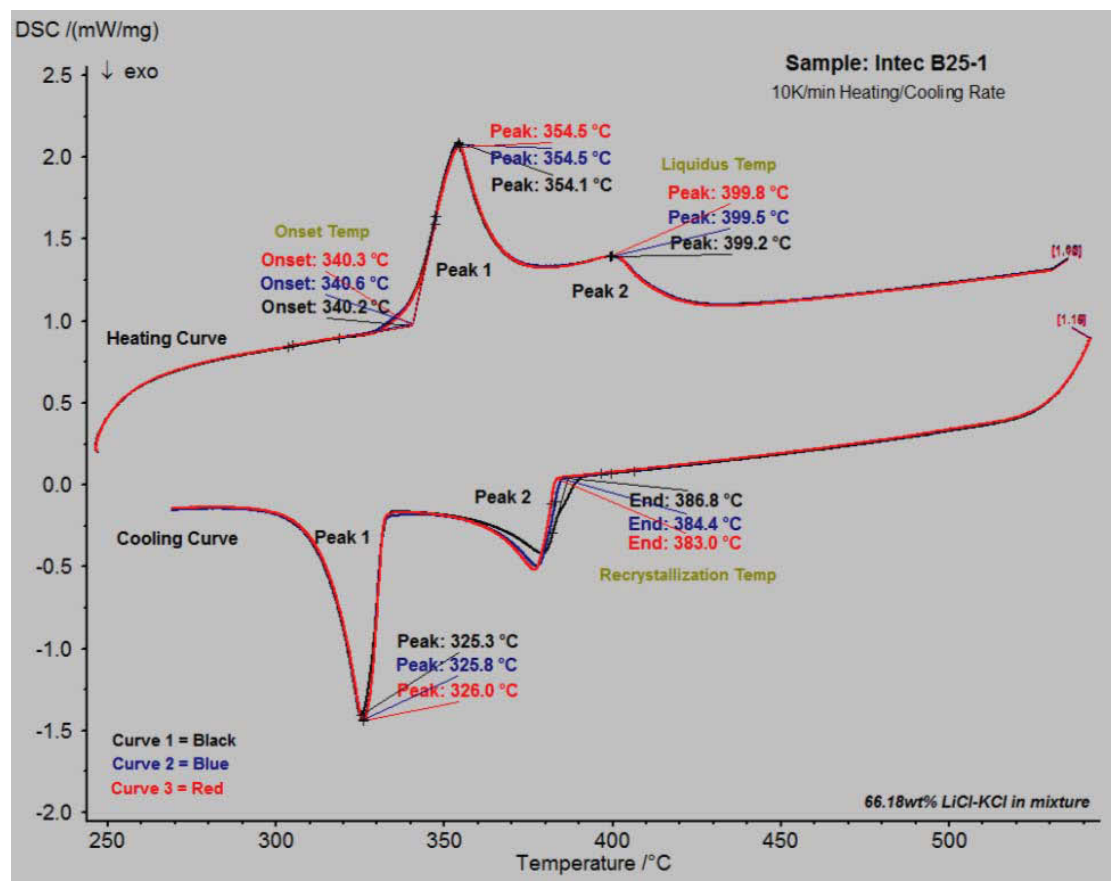

Figure E-2. DSC curves of sample, INTEC B25-1, $10 \mathrm{~K} / \mathrm{min}$ heating rate. 


\section{E2. INTEC B25-2}

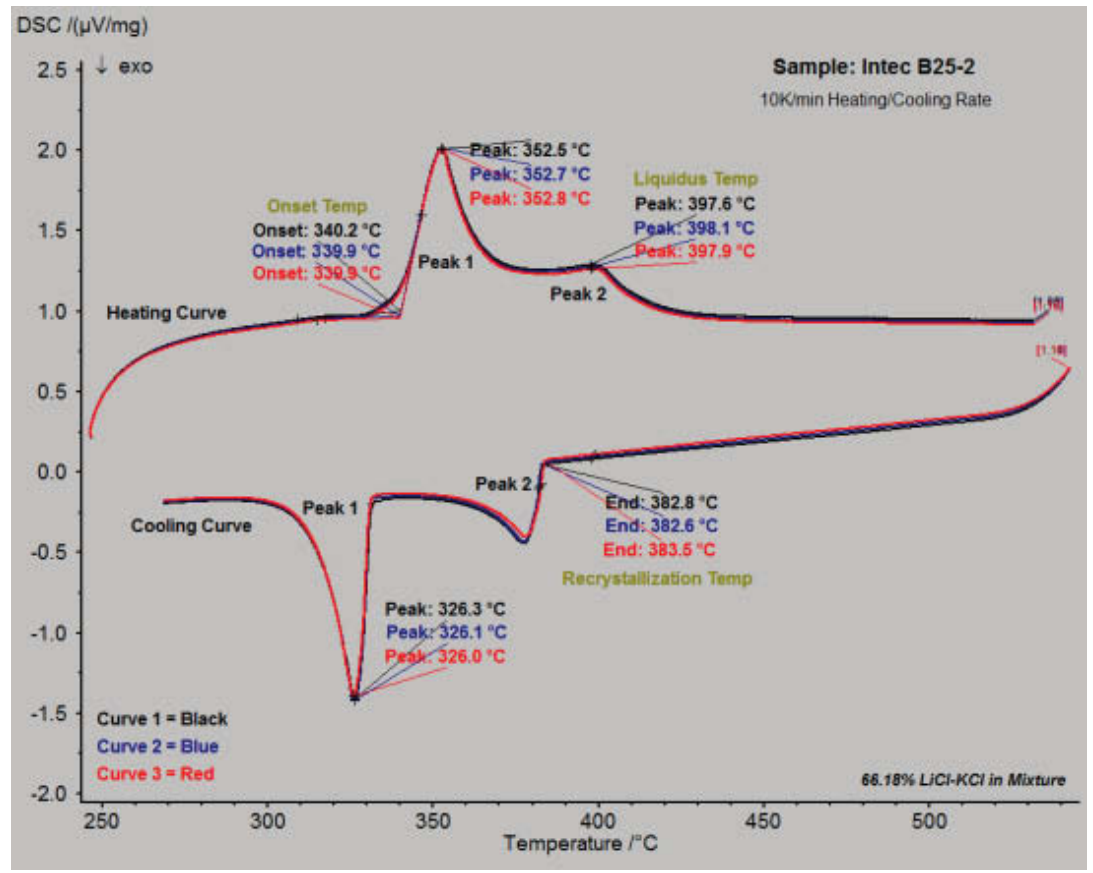

Figure E-3. DSC curves of sample, INTEC B25-2, $2 \mathrm{~K} /$ min heating rate.

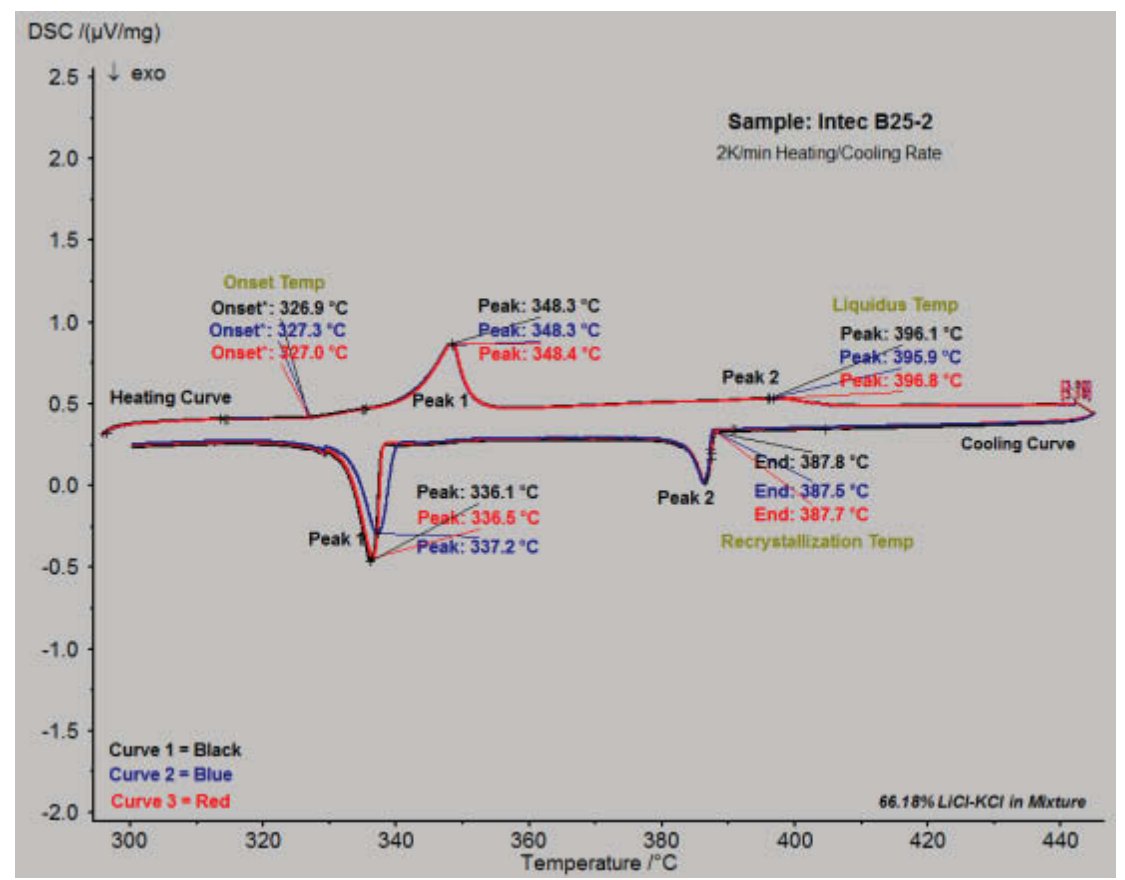

Figure E-4. DSC curves of sample, INTEC B25-2, 10/min heating rate. 


\section{E3. INTEC B50}

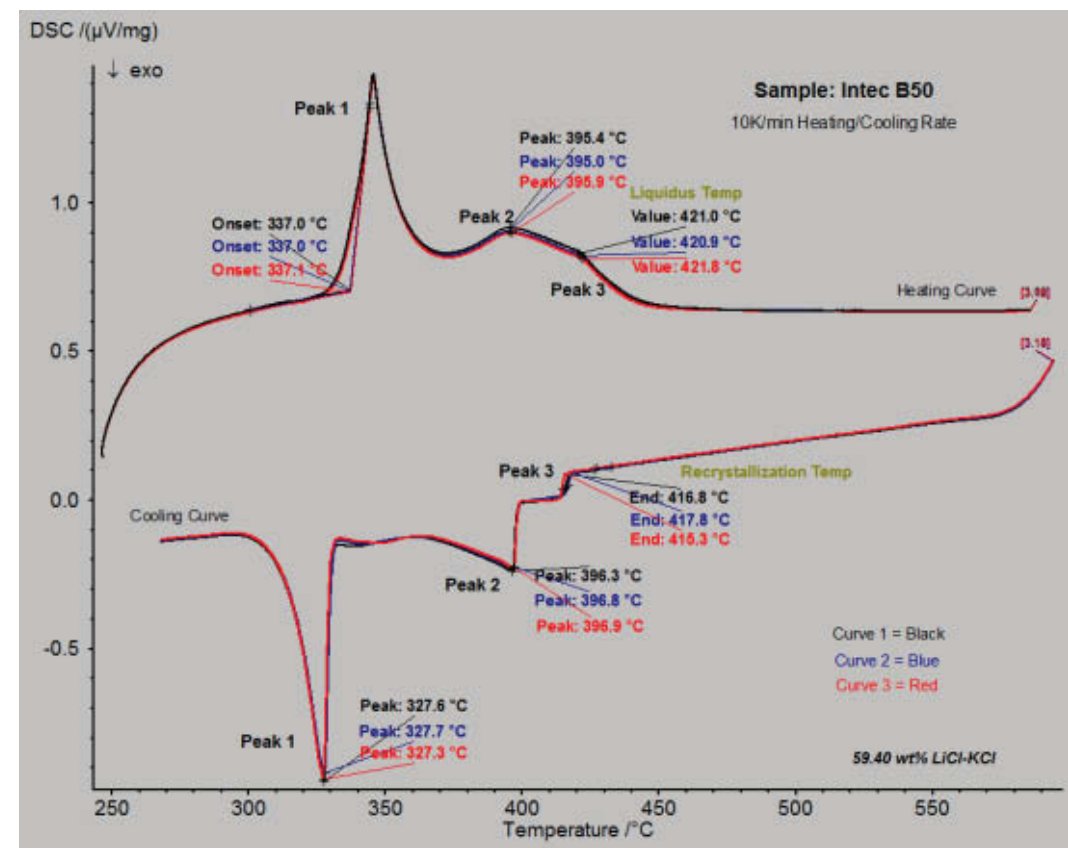

Figure E-5. DSC curves of sample, INTEC B50, $2 \mathrm{~K} / \mathrm{min}$ heating rate.

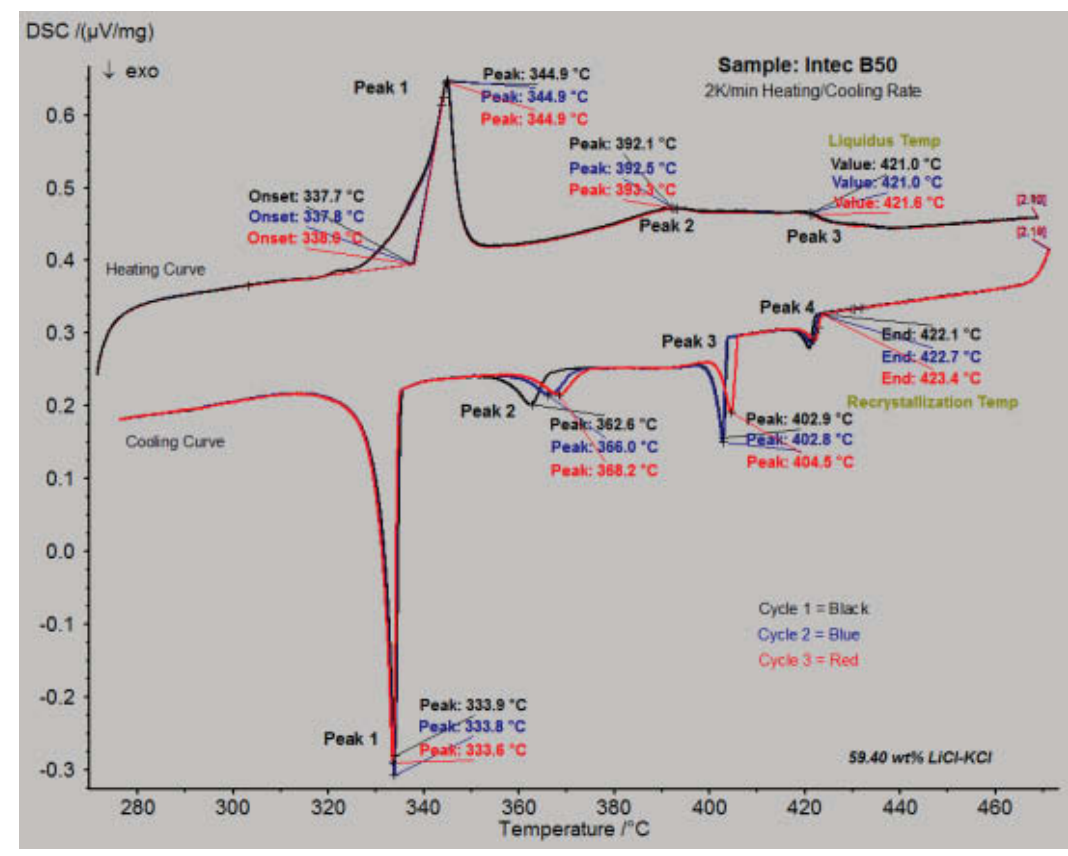

Figure E-6. DSC curves of sample, INTEC B50, $10 \mathrm{~K} / \mathrm{min}$ heating rate. 


\section{E4. INTEC B75}

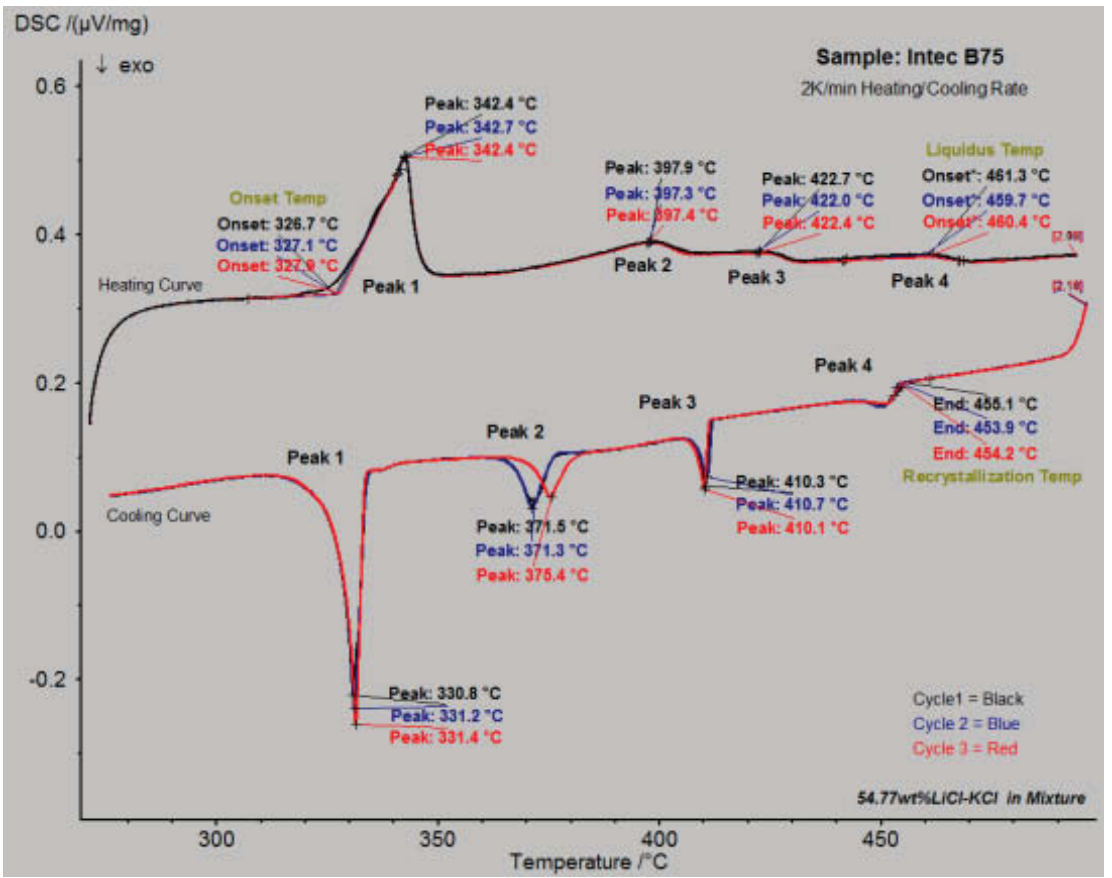

Figure E-7. DSC curves of sample, INTEC B75, $2 \mathrm{~K} / \mathrm{min}$ heating rate.

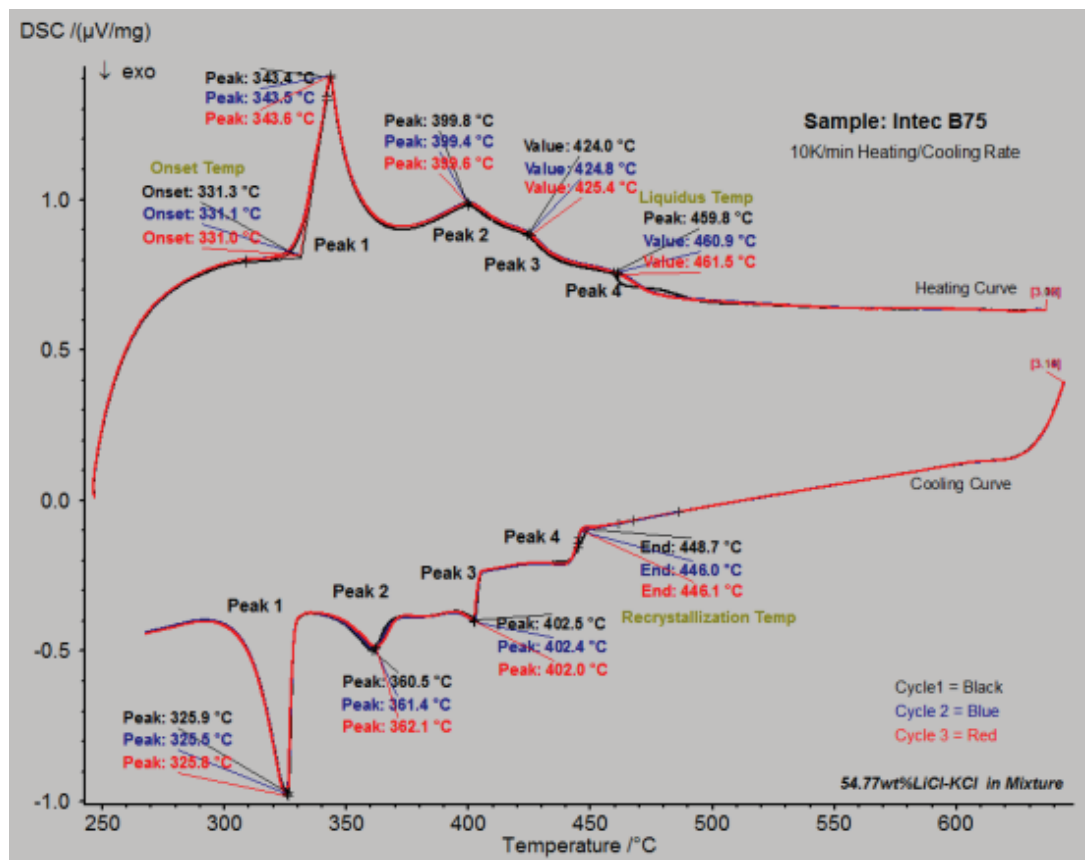

Figure E-8. DSC curves of sample, INTEC B75, $10 \mathrm{~K} / \mathrm{min}$ heating rate. 


\section{E5. INTEC B100}

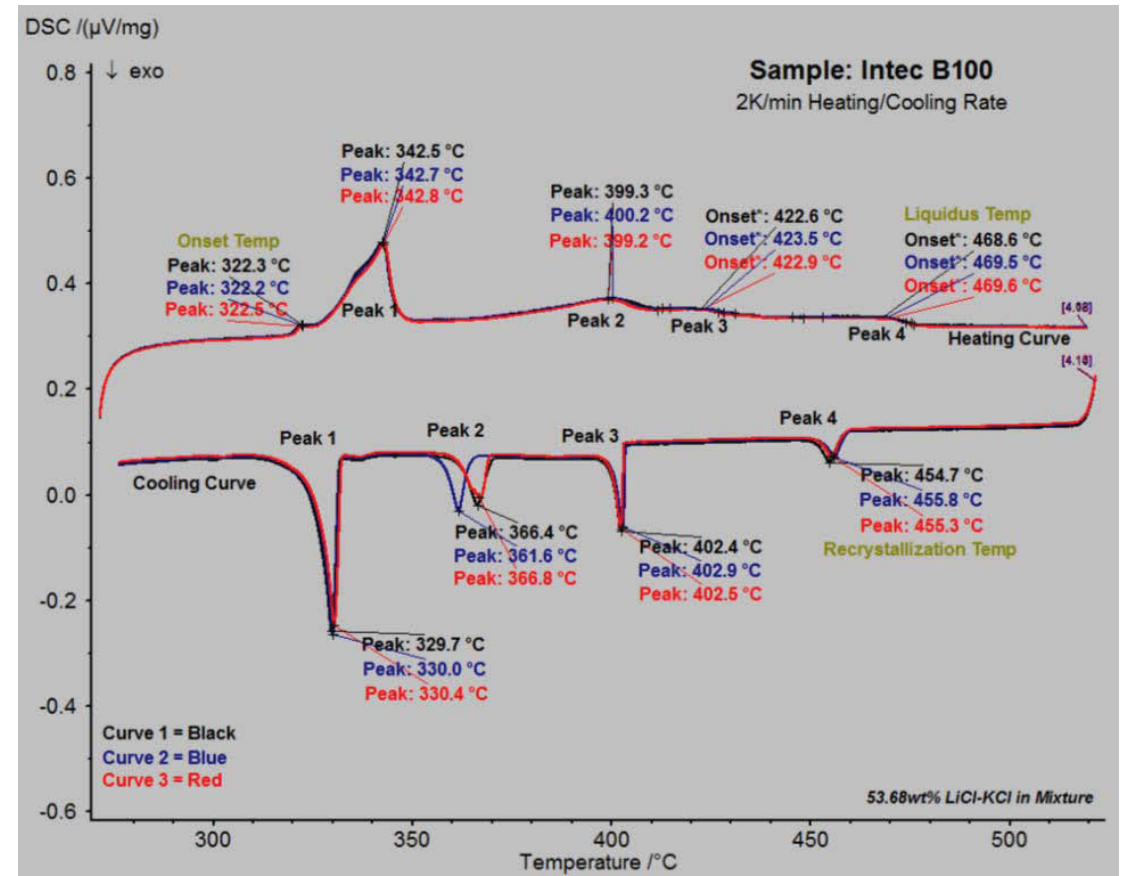

Figure E-9. DSC curves of sample, INTEC B100, $2 \mathrm{~K} / \mathrm{min}$ heating rate.

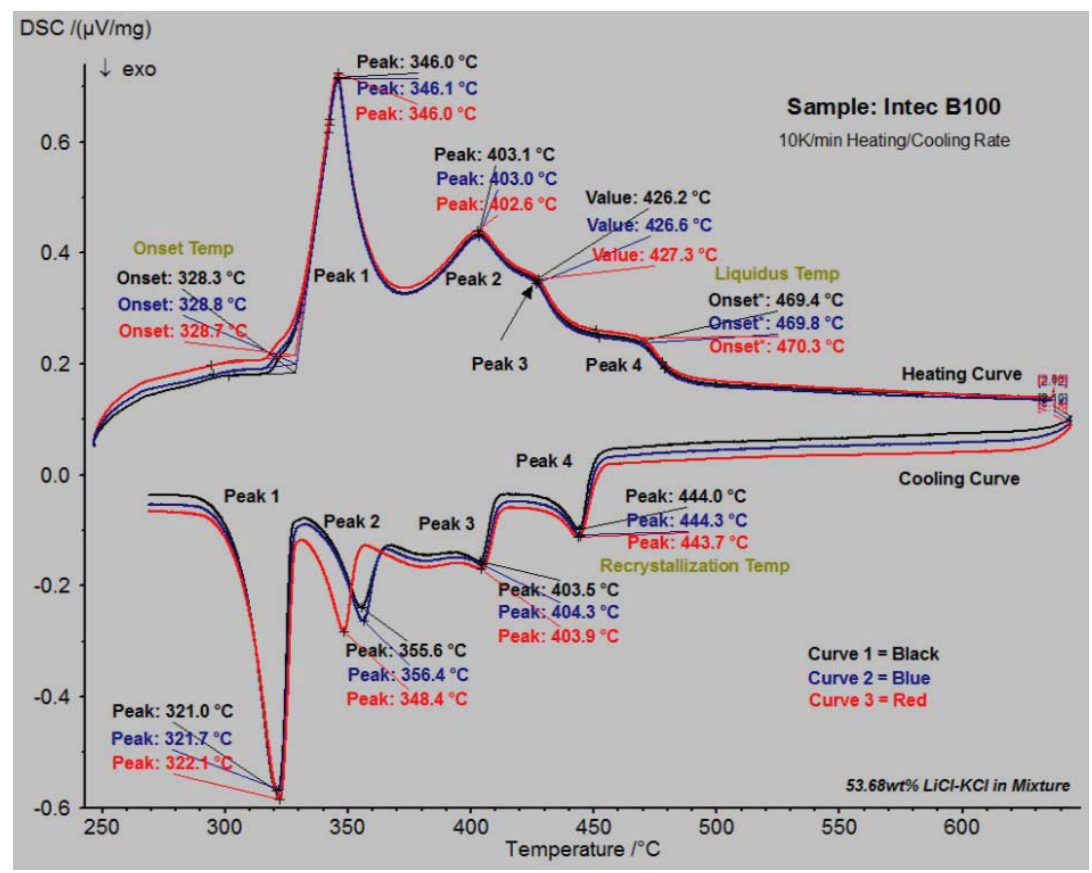

Figure E-10. DSC curves of sample, INTEC B100, $10 \mathrm{~K} / \mathrm{min}$ heating rate. 


\section{E6. INTEC B125}

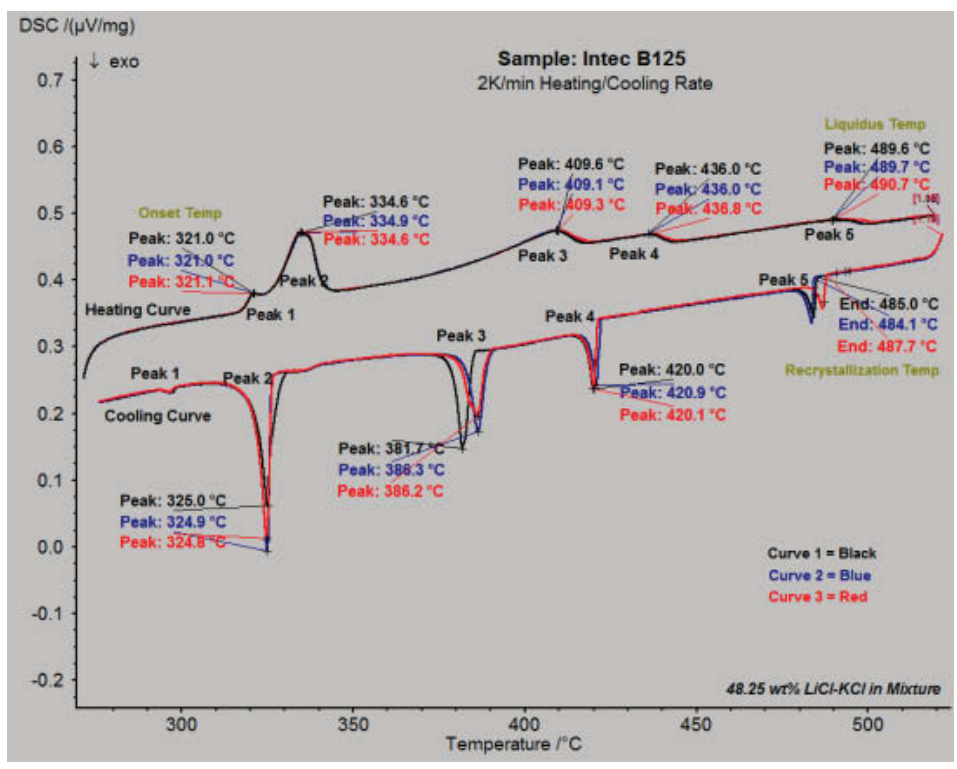

Figure E-11. DSC curves of sample, INTEC B125, $2 \mathrm{~K} / \mathrm{min}$ heating rate.

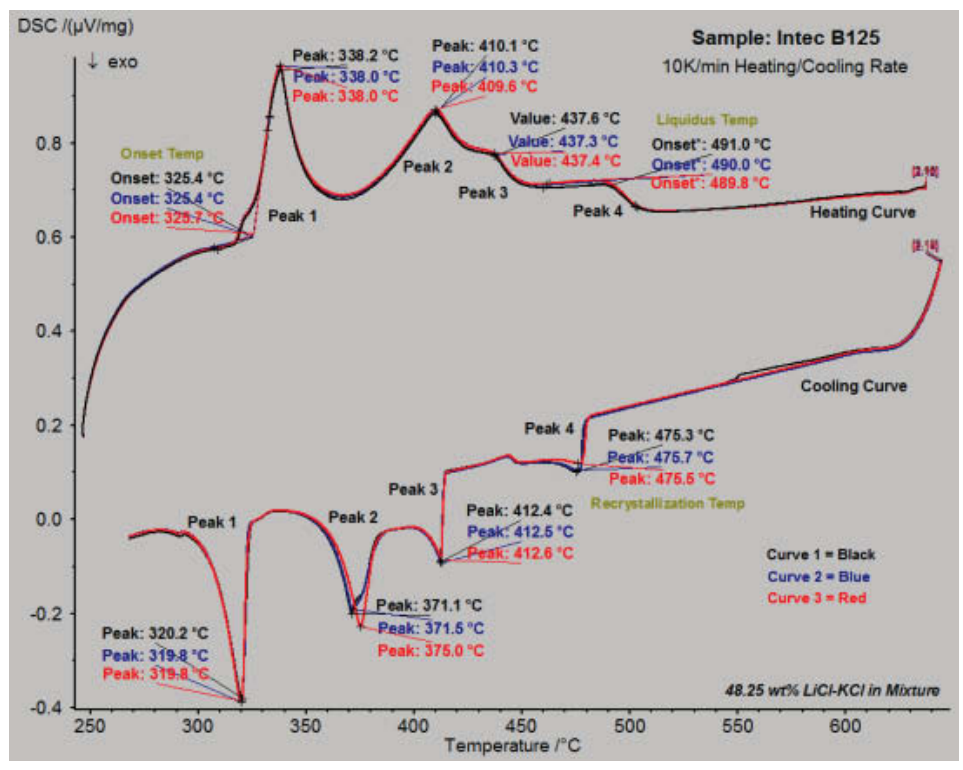

Figure E-12. DSC curves of sample, INTEC B125, $10 \mathrm{~K} / \mathrm{min}$ heating rate. 


\section{E7. INTEC B150}

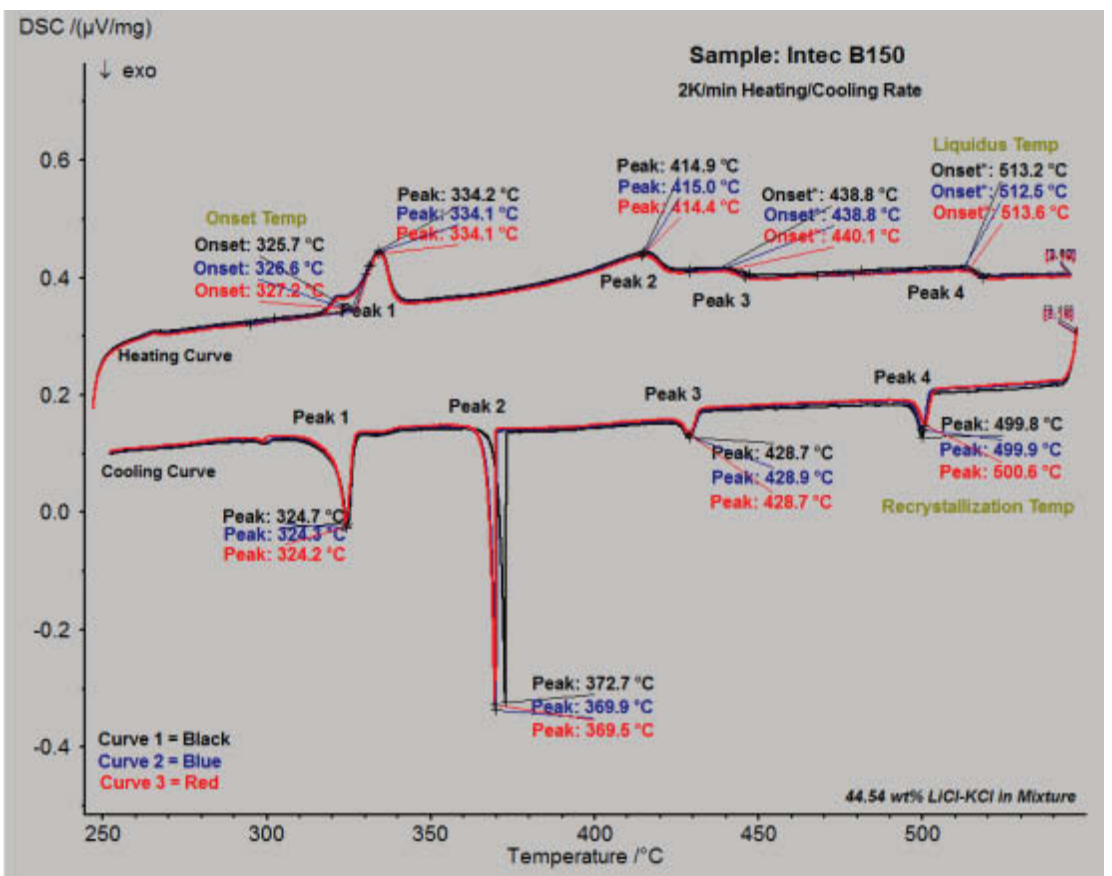

Figure E-13. DSC curves of sample, INTEC B150, $2 \mathrm{~K} / \mathrm{min}$ heating rate.

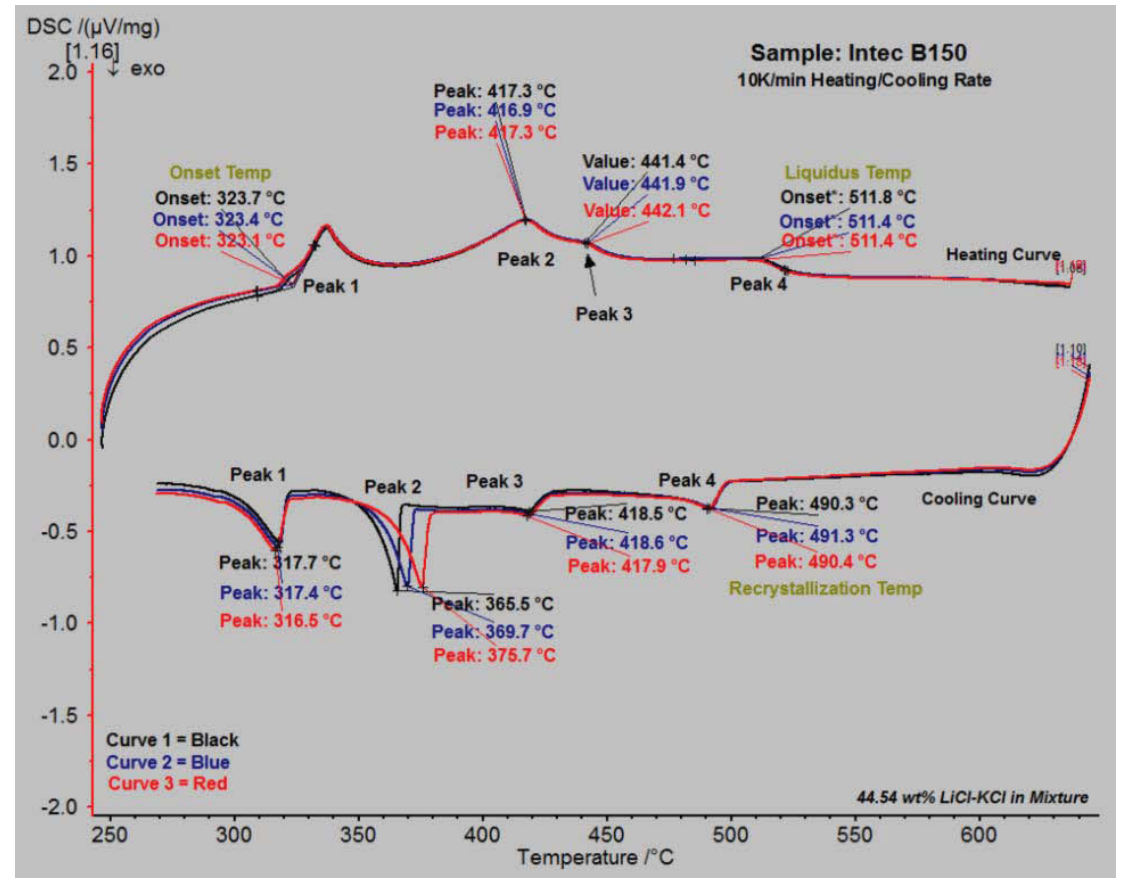

Figure E-14. DSC curves of sample, INTEC B150, $10 \mathrm{~K} / \mathrm{min}$ heating rate. 


\section{E8. INTEC B165}

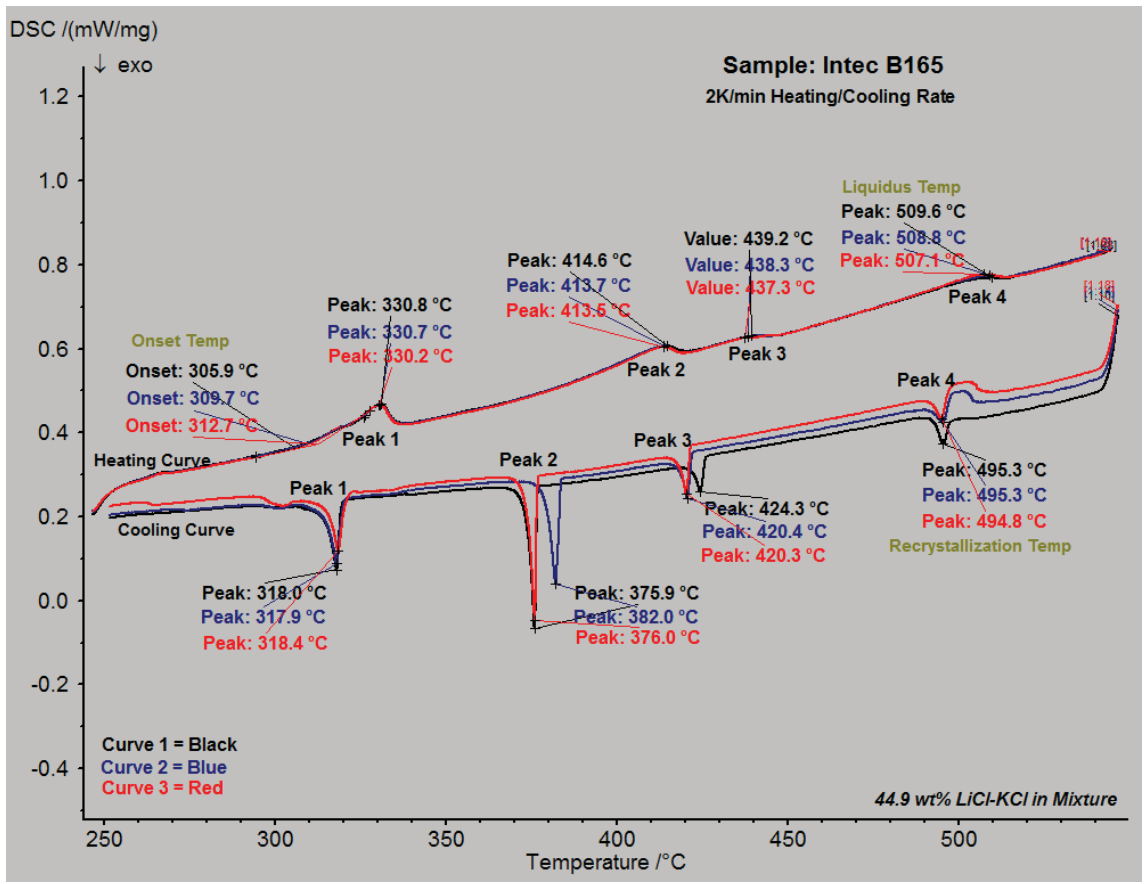

Figure E-15. DSC curves of sample, INTEC B165, $2 \mathrm{~K} / \mathrm{min}$ heating rate.

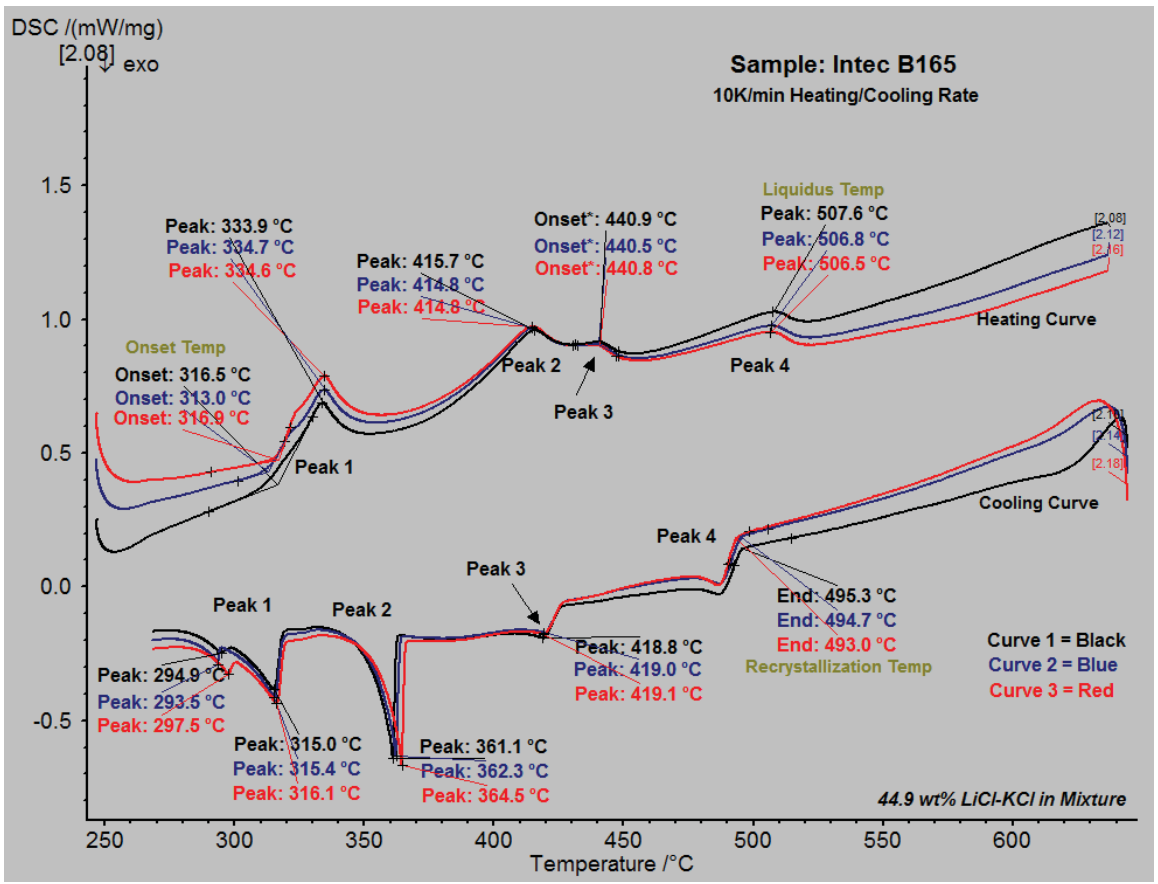

Figure E-16. DSC curves of sample, INTEC B165, $10 \mathrm{~K} / \mathrm{min}$ heating rate. 